\title{
Black Garlic and Its Bioactive Compounds on Human Health Diseases: A Review
}

\author{
Tanvir Ahmed and Chin-Kun Wang *
}

Citation: Ahmed, T.; Wang, C.-K. Black Garlic and Its Bioactive Compounds on Human Health Diseases: A Review. Molecules 2021, 26, 5028. https://doi.org/10.3390/ molecules 26165028

Academic Editor: Francesco Cacciola

Received: 1 July 2021

Accepted: 12 August 2021

Published: 19 August 2021

Publisher's Note: MDPI stays neutral with regard to jurisdictional claims in published maps and institutional affiliations.

Copyright: (c) 2021 by the authors. Licensee MDPI, Basel, Switzerland. This article is an open access article distributed under the terms and conditions of the Creative Commons Attribution (CC BY) license (https:/ / creativecommons.org/licenses/by/ $4.0 /)$.

\author{
Department of Nutrition, Chung Shan Medical University, 110, Section 1, Jianguo North Road, \\ Taichung 40201, Taiwan; tanvirsust2011@gmail.com \\ * Correspondence: wck@csmu.edu.tw; Tel.: +886-93-664-2829
}

\begin{abstract}
Black garlic (BG) is a form of aged garlic obtained from raw garlic (Allium sativum) via Millard reaction under high temperature $\left(60-90{ }^{\circ} \mathrm{C}\right)$ and humidity $(70-90 \%)$ for a period of time. Several studies reported higher contents of water-soluble antioxidants compounds (S-allyl cysteine, S-allyl-mercapto cysteine), 5-hydroxymethylfurfural, organosulfur compounds, polyphenol, volatile compounds, and products of other Millard reactions compared to fresh garlic after the thermal processing. Recent studies have demonstrated that BG and its bioactive compounds possess a wide range of biological activities and pharmacological properties that preserve and show better efficacy in preventing different types of diseases. Most of these benefits can be attributed to its antioxidation, anti-inflammation, anti-obesity, hepatoprotection, hypolipidemia, anti-cancer, anti-allergy, immunomodulation, nephroprotection, cardiovascular protection, and neuroprotection. Substantial studies have been conducted on BG and its components against different common human diseases in the last few decades. Still, a lot of research is ongoing to find out the therapeutic effects of BG. Thus, in this review, we summarized the pre-clinical and clinical studies of BG and its bioactive compounds on human health along with diverse bioactivity, a related mode of action, and also future challenges.
\end{abstract}

Keywords: black garlic; health diseases; health benefits; bioavailability

\section{Introduction}

With the prevalence of chronic diseases and their associated pathological complications, health has become the top of scientific research priorities, with the goal of finding novel foods and tactics to tackle such public health burdens. The scientific literature has recently witnessed flourishing pharmaceutical and nutrition research to use food plants for their diverse health advantages and possible therapeutic uses. A fundamental objective of this nutritional research is to give scientific knowledge to optimize health, and prevent or delay the development of illness. An increasing amount of scientific data suggests that dietary interventions, particularly those that provide high levels of plant foods, can prevent or delay the growth of chronic age-related pathologies by safeguarding the body's critical physiological systems. The prohibitive effect of plant foods has been investigated as a novel therapeutic remedy for the presence of pharmacologically active substances. Besides, plant foods, and many of their derivative products, i.e., extract, contain various micronutrients (minerals and vitamins), fibers, and bioactive compounds, known as phytochemicals. Notably, plant-based dietary pattern foods have improved different intermediary outcomes with a lower incidence of chronic diseases, including cancer, cardiovascular, neurodegenerative diseases, modulate intestinal microbiota composition and functionality with a positive human health impact [1,2].

In the last few decades, single subgroups of botanical agents such as vegetables, fruits, herbs, and nuts, have been taken into consideration to use as nutrient supplements and recognized for their numerous health benefits, including the prevention of diseases [3-5]. Among these, garlic (Allium sativum) has been one of the most important dietary sources not only for health benefits but also as a traditional medicinal all over the world [6-10]. Despite 
all of the health benefits of garlic, the current global consumption of garlic is declining. Some people are unwilling to eat fresh garlic due to its pungent, offending taste and smell, and it can cause gastrointestinal discomfort in some people [11,12]. Therefore, researchers are trying to use raw garlic in different forms such as smocked garlic, garlic oil macerate, garlic juice, supplement pill, garlic powder, etc., to alleviate these discomforts $[13,14]$.

Among the commercially available various garlic processing products, black garlic (BG) has been well known as the fastest-growing health food and is the most studied [15]. Although BG's origin remains dubious, the product is believed to have been consumed in Korea, Japan, and Thailand from ancient times; in 2014, BG reported an estimated market value of around $\$ 94$ million [16]. BG is a form of aged garlic obtained from raw garlic (Allium sativum) via the Millard reaction under high temperature $\left(60-90^{\circ} \mathrm{C}\right)$ and humidity $(70-90 \%)$ for a period of time $[17,18]$. The offensive and harsh odor of fresh garlic are converted into a chewy texture and sweet taste during the aging process [19]. The aging process not only modifies the nutrients and sensory attributes of BG but also improves bioactivity. The health benefits of BG intake are largely associated with the presence of bioactive substances such as phenol and organosulfur. The bioactive components of BG display a wide variety of physiological functions in the human body, which may have therapeutic potential for treating various diseases. For instance, multiple studies showed the bioactivities of BG, including antioxidation [20], anti-inflammation [21-23], anti-obesity [24,25], hepatoprotection [26-28], hypolipidemia [29,30], anti-cancer [31-33], anti-allergy [34,35], immunomodulation [15,36], cardiovascular prevention $[37,38]$, and neurodegenerative protection [39].

In the last few decades, substantial studies have been conducted on BG and its components against different common human diseases. Still, a lot of research is ongoing to find out the therapeutic effects of BG. However, a review of the health benefits of BG and its components on different common human diseases from fundamental to clinical studies is still lacking. Thus, in this review, we summarize the pre-clinical and clinical studies of BG and its bioactive compounds on human health diseases along with diverse bioactivity, the related mode of action, and also future challenges. We hope a comprehensive overview of published findings on the health benefits of BG and its bioactive compounds can help food and nutrition experts, researchers, and scientists define future research direction with clinical evidence to improve people's health and wellness.

\section{Data Collection}

The authors of this review article carried out a literature search for relevant articles regarding BG effects on human diseases by determining sources or literature in the form of primary data or official books, national or international journals published till May 2021. Additionally, data searches were also conducted using different online platforms. During writing this review article, the main references were cited from the trusted source, such as Google Scholar, Web of Science, Scopus, NCBI, Science Direct, ResearchGate, Medline (PubMed), and other trusted journals publishers.

\section{Thermal Processing of Black Garlic}

The thermal processing of BG from raw garlic has been processed under controlled temperature and relative humidity without additives, which is ready to consume with a sweet taste and slightly pungent odor and taste. Currently, there is no standard procedure for producing BG; processing conditions vary greatly depending on regional traditions and the specific features desired in the ultimate product. Till now, researchers are trying to find out optimal conditions for BG processing and they have already applied different thermal processing plans (Table 1). BG is commonly processed in temperature ranges between $30-90{ }^{\circ} \mathrm{C}, 50-90 \%$ relative humidity, and an incubation period of $10-80$ days [16,40-47]. 
Table 1. Processing conditions of black garlic.

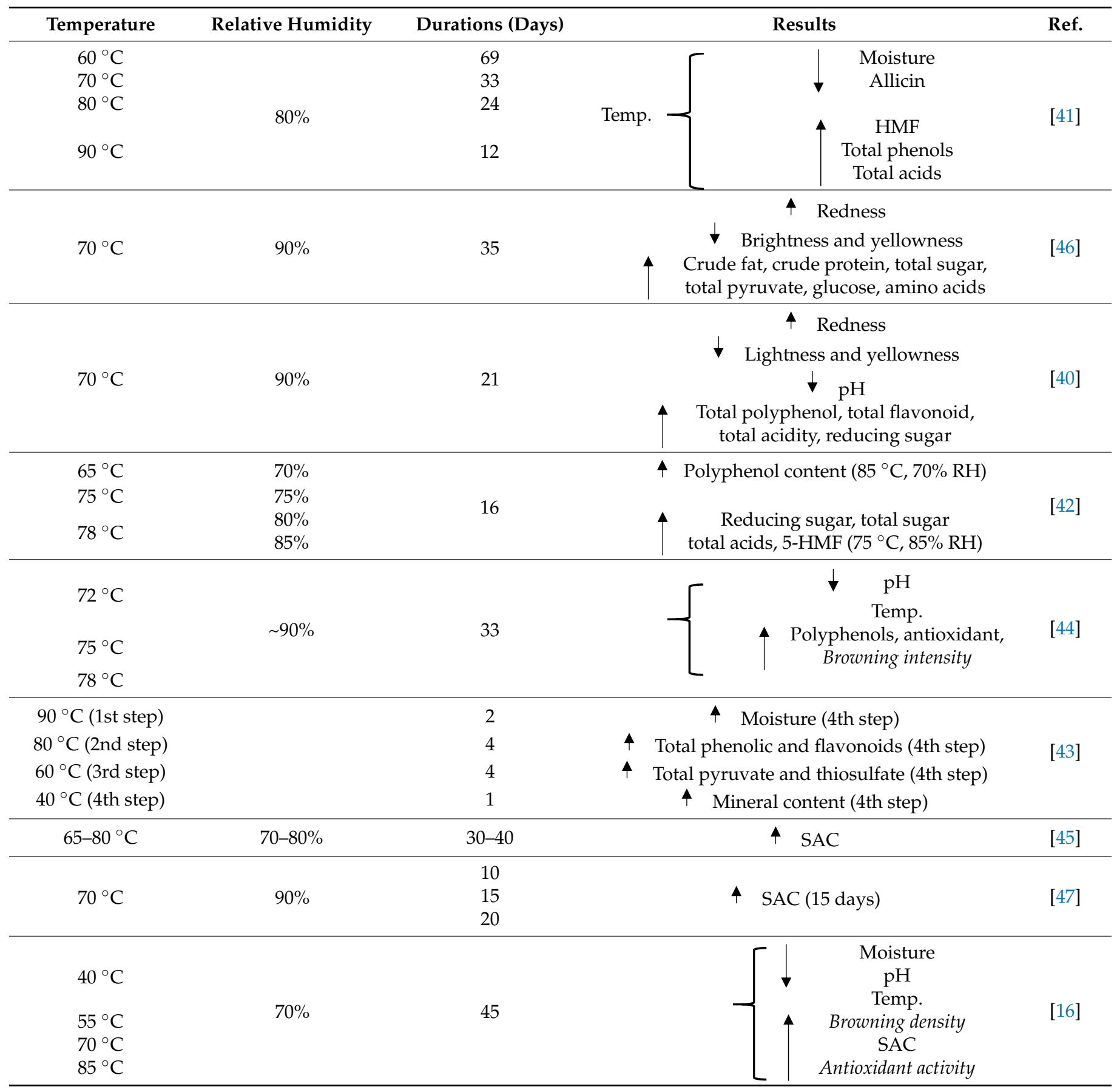

Temp.: temperature; 5-HMF: 5-Hydroxymethylfurfural; SAC: s-allyl cysteine.

Treatments performed prior to the thermal processing of raw garlic to produce BG are referred to as pretreatments and have been shown to impact the attributes of final BG products. Few garlic pretreatments can damage or destroy the garlic's cell structure, allowing immediate reactions between the cell components and external elements during the processing of fresh garlic to BG. The temperature and relative humidity of thermal treatment during $\mathrm{BG}^{\prime}$ 's production are the critical variables among the parameters that influence the quality of BG. For example, the change in the color of garlic was sluggish and not completely black at $80 \%$ relative humidity, and the three days oven drying time at $60{ }^{\circ} \mathrm{C}$; the color change at $70{ }^{\circ} \mathrm{C}$ is substantially more than at $60{ }^{\circ} \mathrm{C}$; black color becomes homogenous when heated to $70-80^{\circ} \mathrm{C}$; at $90^{\circ} \mathrm{C}$, the strong flavor of bitterness and sour 
taste would be noticeable. BG has a dry look at $70{ }^{\circ} \mathrm{C}$ with improved flexibility and quality; bone dry at $80^{\circ} \mathrm{C}$, combustion; very harsh at $90^{\circ} \mathrm{C}$, with a distinct scent of burning. BG has optimum softness and elasticity in the case of the moisture level of $400-500 \mathrm{~g} / \mathrm{kg}$. On the other hand, BG would become considerably drier with poor elasticity when the moisture content reaches in the range of 350-400 g/ kg. In addition, BG would be highly droughty and hard under $350 \mathrm{~g} / \mathrm{kg}$ of moisture content [41].

\section{Composition of Black Garlic}

Carbohydrates $(36 \%)$, fat $(0.5 \%)$, and protein $(6 \%)$ are the major components of fresh garlic. The carbohydrates comprise fructan (23.2-27. $8 \mathrm{~g} / 100 \mathrm{~g})$, sucrose (0.6-0.7 g/100 g), fructose $(0.1 \mathrm{~g} / 100 \mathrm{~g})$, glucose $(0.04-0.05 \mathrm{~g} / 100 \mathrm{~g})$. Another study also showed that garlic contained $60 \%$ water, $28 \%$ carbohydrate, $8.4 \%$ protein, and $0.1 \%$ fat $[11,48,49]$. Compared to garlic and BG, when the garlic was prepared at $60{ }^{\circ} \mathrm{C}$ and $90 \%$ relative humidity for 45 days, the weight of the garlic reduced by $64 \%$, the soluble solid content ( ${ }^{\circ}$ Brix) increased by $13 \%$, and the water activity declined slightly from 0.97 to 0.93 . Besides, moisture content was also reduced one to two times compared with garlic and BG. In addition, the carbohydrate profile of fresh garlic has been drastically changed upon its conversion to BG. For instance, carbohydrate content in the BG compared to fresh garlic was increased by 1- to 2-fold followed by 1.3-1.6 fold, 6-108 fold, and 2-13 fold in the case of sucrose, fructose, and glucose, respectively [11]. When the garlic was prepared for 45 days at $60{ }^{\circ} \mathrm{C}$ and $90 \%$ relative humidity the carbohydrate content increased by $28-47 \%$. During the conversion of fresh garlic to BG by thermal processing, fructans disintegrate progressively into monosaccharides (mostly glucose and fructose), disaccharides, and oligosaccharides by thermally induced degradation and enzymatic cleavage catalyzed by fructan exohydrolase [50,51]. Yuan and his colleagues also obtained similar results in their study and noticed that the fructan levels of garlic were decreased by around 6-fold at $55{ }^{\circ} \mathrm{C}$ incubation with $80 \%$ humidity for 90 days [52]. In BG, monosaccharides became the predominant saccharides, with minor levels of polysaccharides and disaccharides [53]. BG was detected in most of the saccharides and related products at $60-80{ }^{\circ} \mathrm{C}$ for 36 days, whereas a few were found in fresh garlic [54]. According to several studies, polysaccharide breakdown is mostly caused by heat treatment rather than enzymatic hydrolysis, with polysaccharide molecular weight distribution and breakdown rate closely related to processing temperature [55]. However, BG could have a reducing sugar content 20-70 times higher than its original fresh garlic depending on the process of fresh garlic, which causes a distinct sweet taste in BG [41,56].

The lipid contents of fresh garlic and BG also contribute considerably to their sensory properties and serve as a nutrient and energy source. Lipids derived from fresh garlic with chloroform-methanol reportedly constitutes $63 \%$ neutral fluids, $14 \%$ glycolipids, and $24 \%$ phospholipids [57]. Changes in lipid profiles are identified in the development of BG due to their oxidation and engagement in the different chemical processes. Choi et al. [40] demonstrated a notable rise in crude lipid content $(0.15 \%$ to $0.60 \%)$ following fresh garlic processing to BG. In comparison, $\mathrm{Lu}$ [58] observed a considerable rise in crude lipid levels of fresh garlic and BG, respectively, of $0.33 \%$ and $0.16 \%$. These inconsistencies are most likely caused by the garlic variety, processing technique, extraction, and analysis processes as well as moisture content variations of fresh garlic and BG. In the transformation of fresh garlic to BG, hydrolytic and oxidative alterations are conceivable for garlic lipids under high temperature $\left(50-90^{\circ} \mathrm{C}\right)$ and high humidity $(60-90 \%)$. A number of chemicals are therefore formed including alcohols, lactones, aldehydes, and ketones. These compounds, together with fatty, take part in a range of complex chemical processes involving Millard reaction, oxidation, and hydrolysis [59].

Fresh garlic is abundant in free amino acids and asparagine, glutamic acid, valine, lysine, and tryptophan are the most predominant free amino acids available in fresh garlic [60]. The processing of BG impacts secondary, tertiary, and/or quaternary protein structures, but is unlikely to disintegrate new free amino acids from covalent peptide bonds. When fresh garlic is converted to BG at high temperatures, protein is denatured, 
and some free amino acids participate in the Millard reaction. The amino acid profile varies significantly depending on the conditions under which the fresh garlic is converted to BG. For example, Lu [58] found a decrease in the overall amount of 18 free amino acids from 2000 to $1400 \mathrm{mg} / 100 \mathrm{~g}$ fresh matter (FM) with increased levels of leucine, isoleucine, valine, phenylalanine, cysteine, alanine, and aspartic acid. Another study showed the contents of branched amino acids such as leucine $(60-70 \mathrm{mg} / 100 \mathrm{~g})$ and isoleucine $(58-50 \mathrm{mg} / 100 \mathrm{~g})$ were increased in BG when compared with fresh garlic at $70{ }^{\circ} \mathrm{C}$ and $90 \%$ relative humidity [46]. In addition, several amino acids, especially tyrosine and cysteine, decrease in content due to the link with the Millard reaction-possibly being closely connected with changes in the antioxidant activity when fresh garlic is transformed into BG [61].

Garlic is one of the most abundant sources of phenolic compounds among the vegetables consumed by humans. The total quantities of phenolic compounds in fresh garlic range from 3 to $11 \mathrm{mg}$ gallic acid equivalent (GAE)/g dry matter (DM) with a mean level of $6.5 \mathrm{mg}$ GAE/g DM. In addition, the overall concentration of phenolic acid varies from 2 to $20 \mathrm{mg} / \mathrm{kg}$ DM with an average of $7.6 \mathrm{mg} / \mathrm{kg}$ DM and caffeic acid is the most predominant content (average $3 \mathrm{mg} / \mathrm{kg} \mathrm{DM}$ ) [62]. The polyphenol level was enhanced by $2.8 \%$ with the antioxidant activity $(6.7 \%)$ when fresh garlic was prepared at $60{ }^{\circ} \mathrm{C}$ and $90 \%$ relative humidity for 45 days. Phenol-like substances were increased 3- to 4-fold in comparison to fresh garlic and BG, whereas flavonoid-like compounds and antioxidant compounds increased by 2- to 8-fold and 3- to 7-fold, respectively. In general, the polyphenol contents of BG are three times greater in whole BG bulbs as compared to fresh garlic bulbs, and six times greater in BG cloves peeled $[18,35,43,46,63]$. As a result, BG exhibits greater antioxidants than fresh garlic. However, processing fresh garlic for a long duration at high temperatures could lead to a drop in certain phenolic substances due to the loss of polyphenols that are freshly generated or released [18].

Recently, an amino acid-containing molecule S-allyl cysteine (SAC) has received more attention since it is the most predominant antioxidant of $\mathrm{BG}$ and is a biologically active and health-beneficial compound found in both fresh garlic and BG [64]. SAC in fresh garlic was reported between 21 to $23 \mu \mathrm{g} / \mathrm{g}$ FM and could be considerably higher, three to six times as much as fresh garlic, depending on the thermal treatment. Bae et al. [16] found in their study that the SAC content of BG was $124.67 \mu \mathrm{g} / \mathrm{g}$ DM when manufactured at $40{ }^{\circ} \mathrm{C}$ for 45 days, but the SAC content decreased to $85.46 \mu \mathrm{g} / \mathrm{g}$ DM in the BG when the temperature raised to $85{ }^{\circ} \mathrm{C}$. Another study reported the higher SAC content in the BG and also noticed that when the fresh garlic was heated at $60^{\circ} \mathrm{C}$ and $90 \%$ relative humidity for 45 days, the amino acids and SAC levels are enhanced three and eight times, respectively [49].

Similarly, hydroxymethylfurfural (HMF) is one of the major antioxidant ingredients in BG. Besides, the black color formation of the garlic sample is related to the formation of HMF. Zhang et al. [41] processed garlic to BG at a temperature of $60{ }^{\circ} \mathrm{C}, 70{ }^{\circ} \mathrm{C}$, $80^{\circ} \mathrm{C}$, and $90^{\circ} \mathrm{C}$ and monitored the HMF concentration till maturity. When HMF reached $4 \mathrm{~g} / \mathrm{kg}$, samples of garlic were mainly aged and turned black. $90^{\circ} \mathrm{C}$-processed samples attained maturity around 9 days, $80^{\circ} \mathrm{C}$-processed samples in approximately 21 days, and $70{ }^{\circ} \mathrm{C}$-processed samples in about 33 days, and at $60^{\circ} \mathrm{C}$ the HMF concentration increased very slowly throughout the procedure, resulting in a lower-quality garlic product. HMF levels were sharply increased yet the color and flavor of garlic samples decreased with high temperatures. When the BG production process was carried out at a temperature of $70{ }^{\circ} \mathrm{C}$, the highest-grade items were achieved. In another study, Liang et al. [51] demonstrated that during the processing of fresh garlic in BG, a substantial amount of HMF was generated and the BG extracts acquired in 90 days of thermal processing had an increased HMF content by more than six times, compared to those heated in 25 days. In addition, Li et al. [65] observed that the HMF content in BG could be increased up to $25 \%$ by freezing treatment.

Citric acid, which is the most abundant in organic acid, is also found in garlic in relatively large quantities compared to other organic acids such as lactic acid, fumaric acid, 
malic acid, and formic acid [51,66]. In a study, Bae et al. [16] reported a $\mathrm{pH}$ decreased from 6 to 5 or 3 after heating the fresh garlic at $40{ }^{\circ} \mathrm{C}$ or $85^{\circ} \mathrm{C}$ for 45 days. Zhang et al. [41] observed in their study that the total acid content had been modified from $4.5 \mathrm{~g} / \mathrm{kg}$ to 33.50 , $37.50,30.90$, and $36.35 \mathrm{~g} / \mathrm{kg}$, respectively, during the transformation of fresh garlic to BG at $60{ }^{\circ} \mathrm{C}, 70{ }^{\circ} \mathrm{C}, 80^{\circ} \mathrm{C}$, and $90^{\circ} \mathrm{C}$. Moreover, Liang et al. [51] found that after the fermentation process, the BG extracts newly formed a higher amount of formic acid and acetic acid. Such changes in organic acid are important because a higher organic acid content not only provides a sweet-sour flavor, it also accelerates the breakdown of proteins, polysaccharides, and the microbiological stability of BG samples $[67,68]$. The increased acidity of fresh garlic after the heat treatment is mainly due to the degradation of a large number of alkaline groups and the formation of short-chain carboxylic acids during reactions such as the Millard reaction [69].

Fresh garlic also contains a number of enzymes, which affect the quality of the final BG products. Superoxide dismutases (SODs) are possibly a class of enzymes found exclusively in garlic. These enzymes are not only important free radical scavengers in a growing microorganism, but they also perform crucial biological functions. Sato et al. [63] revealed that fresh garlic had SOD-like activities; $80 \%$ ethanol extract from garlic fermented for 40 days at 60 to $70{ }^{\circ} \mathrm{C}$ and $85 \%$ to $95 \%$ relative humidity exhibited a 13-fold increase in SOD-like activities. Furthermore, fresh garlic also contains multiple water-soluble vitamins and trace elements. The fresh garlic processing at different temperatures and humidity would increase 1.15 to 1.92 times more in total water-soluble vitamins. The garlic samples treated for $60 \mathrm{~h}$ at $70{ }^{\circ} \mathrm{C}$ and $60 \%$ relative humidity showed the highest amounts of water-soluble vitamins $(11,600 \mathrm{mg} / \mathrm{kg})$ than fresh garlic $(6633 \mathrm{mg} / \mathrm{kg})$ [70]. In addition, garlic also provides a remarkable amount of several minerals ranging from $0.70 \%$ to $0.80 \%$ of FM [71,72]. Kang reported that different thermal treatments significantly altered the mineral profile of garlic and found that manufacturing garlic for $192 \mathrm{~h}$ at $65^{\circ} \mathrm{C}$ and $50 \%$ relative humidity increased the selenium content with sodium, iron, and calcium [73].

\section{Formation of Phytochemicals of Black Garlic during Millard Reaction}

BG has become one of the world's fastest-growing health products with increased awareness about the health benefits of garlic. Thermal techniques are frequently employed in food production. One of the major goals of thermal procedures is to increase the sensory quality, palatability, and diversity of colors, aroma, taste, and textures of food. Furthermore, the thermal process produced biological compounds, which are not initially present in foodstuffs (Figure 1) [74]. When BG goes through a natural fermentation or aging process, the garlic cloves turn from white to brown and then finally black due to the Millard reaction. The Maillard reaction alternatively refers to as the amino-carbonyl reaction, is a non-enzymatic process that occurs between reducing sugars and the amino group found in amino acids, peptides, and proteins [75]. In addition, the Maillard reaction was classified into three phases, the first of which began with the reaction between the carbonyl group and reducing sugars and the amino groups of amino acids and continued until the Amadori products (i.e., glucose) or Heyn's products (i.e., fructose) were formed. The intermediate stage involves the fragmentation of sugars and the degradation of amino acids, which resulted in the formation of a variety of intermediates, most notably dicarbonyl compounds. At the final stage, the intermediates are polymerized, resulting in the development of high molecular weight products, particularly melanoidins (Figure 1) [76]. 
<smiles>C=CCSC[C@H](N)C(=O)O</smiles>

S-allyl-L-cysteine (SAC)<smiles>C=CCSSCC(N)C(=O)O</smiles>

S-allylmercaptcysteine (SAMC)<smiles>CSCC(N)C(=O)O</smiles>

S-methyl-L-cysteine (SMC)

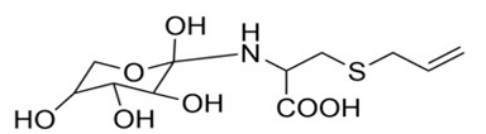

Fructosyl-S-allylcysteine (Fru-SAC)<smiles>C=CCSCC(NC(=O)CCC(N)C(=O)O)C(=O)O</smiles>

$\gamma$-glutamyl-s-allylcysteine (GSAC)
$\mathrm{O}_{\mathrm{OH}}^{\mathrm{OH}} \mathrm{COOH}_{\mathrm{CH}}^{\mathrm{OH}}$

Fructosyl- $\gamma$-glutamyl-S-allylcysteine (Fru-GSAC)

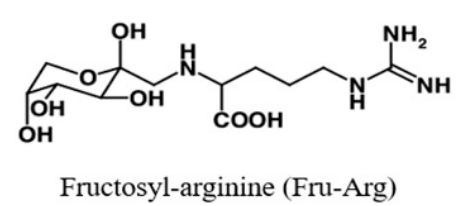<smiles>C=CCSCC=C</smiles>

Diallyl sulfide (DAS)<smiles>O=Cc1ccc(CO)o1</smiles>

5-Hydroxymethyl furfural (5-HMF)<smiles>CC1NC(C(=O)O)Cc2c1[nH]c1ccccc21</smiles>

1-methyl-1,2,3,4-tetrahydro$\beta$ - carboline-3-carboxylic acids (MTCC)

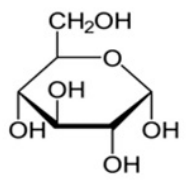

Glucose

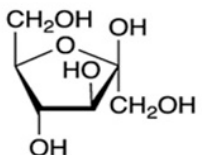

Fructose<smiles>CC(=O)C(=O)O</smiles>

Pyruvic acid
HO $\mathrm{OH}_{\mathrm{OH}}^{\mathrm{OH}} \underbrace{\mathrm{O}}_{\mathrm{COOH}}$

Fructosyl- $\gamma$-glutamyl-S-1-propenylcysteine (Fru-GS1PC)
Diallyl disulfide (DADS)

Diallyl trisulfide (DATS)<smiles>OC1Cc2ccccc2OC1c1ccccc1</smiles>

Flavanols<smiles>O=c1c(O)c(-c2ccccc2)oc2ccccc12</smiles>

Flavonols<smiles>CC1(C(=O)O)NC(C(=O)O)Cc2c1[nH]c1ccccc21</smiles>

1-methyl-1,2,3,4-tetrahydro-

$\beta$ - carboline-3-dicarboxylic acids (MTCdiC)<smiles>O=S(O)(O)=S</smiles>

Thiosulfuric acid<smiles>O=C(O)/C=C/c1ccc(O)cc1</smiles><smiles>O=C(O)/C=C/c1ccccc1O</smiles>

o-Coumaric acid

Figure 1. Cont. 


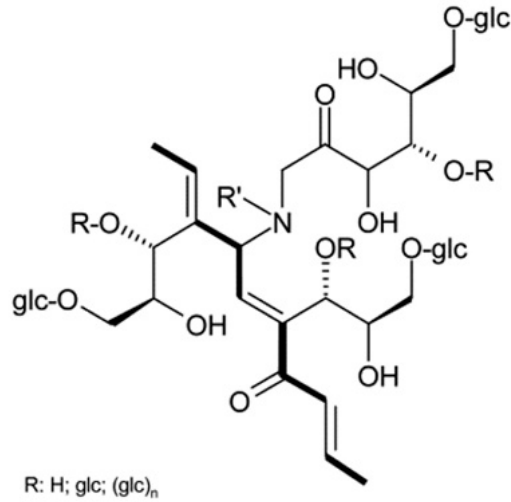

Melanoidins<smiles>N[C@@H](Cc1c[nH]c2ccccc12)C(=O)O</smiles>

Tryptophan<smiles>NCC(=O)O</smiles>

Glycine

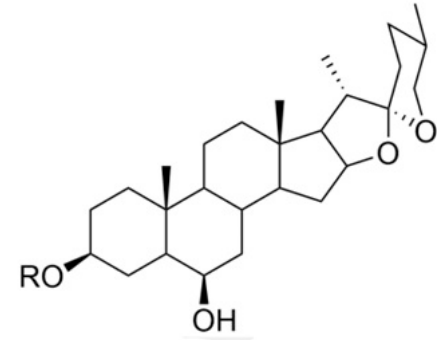

Spirostanol form saponin<smiles>N[C@@H](Cc1c[nH]cn1)C(=O)O</smiles>

Histidine<smiles>N=C(N)NCCCC(N)C(=O)O</smiles>

Arginine

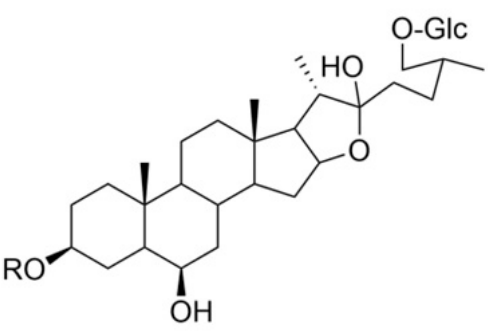

Furostanol form saponin<smiles>CC(C)C(N)C(=O)O</smiles>

Valine<smiles>N[C@@H](CC(=O)O)C(=O)O</smiles>

Aspartic acid

Figure 1. Chemical structures of compounds predominately found in black garlic.

The concentration of Amadori and Heyns compounds in garlic was determined by ion-pair RP-HPLC-UV in BG and dehydrated garlic as a product of acid hydrolysis such as $\mathrm{N}-\varepsilon$-2-furoylmethyl-amino acids (2-FMAAs). The total levels of the three major Amadori compounds such as fructose-proline, fructose-leucine, fructose-valine, and Heyns compounds, i.e., glycosyl-proline, glycosyl-leucine, and glycosyl-valine, varied between 763.1 and $281.5 \mathrm{~g} / \mathrm{g}$ of product in five samples of Chinese commercial BG. In the case of 2-FMAAs, 2-Furoylmethyl-Lysine, 2-Furoylmethyl-Arginine, and 2-Furoylmethyl$\gamma$-Aminobutyric acid were identified in commercial BG in the range between 62.5 and $144.90 \mathrm{mg}$ 2-FMAAs/100 g protein with furosine being the most prevalent [77]. These furoylmethyl amino acids, particularly furosine, are generated after acid hydrolysis of Amadori and Heyns products and in the early stage of Millard reaction, these compounds are recognized as indicator compounds.

On the other hand, during the manufacturing process of BG, 5-hydroxymethyl furfural (5-HMF) other derivatives such as 5-(hydroxymethyl-2)-furoic acid (5-HMFA) are also developed during the intermediate stage of the Millard reaction as a result of Amadori and Heyns product degradation. During the aging process of BG, the content of 5-HMF, and 5-HMFA may increase [51]. However, the 5-HMF formation is associated with the black color intensity. The color of the garlic turns black when the 5-HMF content reaches around $4 \mathrm{~g} / \mathrm{kg}$. In this context, Zhang et al. [41] showed similarity as they obtained the maximum concentration of 5-HMF around $5 \mathrm{~g} / \mathrm{kg}$ after the manufacturing process of BG. Similarly, Sun and Wang [42] reported a higher content of 5-HMF up to $7 \mathrm{~g} / \mathrm{kg}$ at high temperature $\left(75^{\circ} \mathrm{C}\right)$ and relative humidity $(85 \%)$ for 12 days (Table 2$)$. 
Melanoidins are carbohydrate- and nitrogen-based polymers with a brown color, high molecular weight, and varying degrees of polymerization that are frequently generated in the late stages of the Maillard reaction during the preparation of BG. The overall contents of melanoidin increased by thermal processing of fresh garlic into BG from trace level to a high level with a concurrent increase in brownness (Table 2) [52]. In addition, few important intermediates such as furan, thiophene, and pyrazine, which give a more intense and desirable aroma in BG, are also produced with melanoidins [78].

Table 2. Phytochemical contents in fresh garlic and black garlic.

\begin{tabular}{|c|c|c|c|}
\hline Phytochemical & Total Content in Fresh Garlic & Total Content in Black Garlic & Ref. \\
\hline Amino acid & $\begin{array}{c}843.11 \pm 3.75 \mathrm{mg} / 100 \mathrm{~g} \\
121.38 \pm 4.72 \mathrm{mg} / 100 \mathrm{~g} \\
19.43 \pm 0.01 \mathrm{mg} / \mathrm{g} \mathrm{FM} \\
57.66 \mathrm{mg} / \mathrm{g} \text { sample powder } \\
1943.77 \pm 161.22 \mathrm{mg} / 100 \mathrm{~g} \\
1528.75 \pm 0.83 \mathrm{mg} / 100 \mathrm{~g}\end{array}$ & $\begin{array}{c}167.65 \pm 1.08-363.10 \pm 1.05 \mathrm{mg} / 100 \mathrm{~g} \\
60.84 \pm 5.75-108.66 \pm 12.95 \mathrm{mg} / 100 \mathrm{~g} \\
14.86 \pm 0.01 \mathrm{mg} / \mathrm{g} \text { FM } \\
44.01 \mathrm{mg} / \mathrm{g} \text { sample powder } \\
1486.65 \pm 112.62 \mathrm{mg} / 100 \mathrm{~g} \\
1931.13 \pm 175.48 \mathrm{mg} / 100 \mathrm{~g}\end{array}$ & $\begin{array}{l}{[73]} \\
{[46]} \\
{[79]} \\
{[80]} \\
{[81]} \\
{[40]}\end{array}$ \\
\hline Minerals & $\begin{array}{c}1173.50 \pm 2.43 \mathrm{mg} / 100 \mathrm{~g} \\
15,908 \mathrm{mg} / \mathrm{kg} \text { dry powder } \\
567.88 \pm 4.48 \mathrm{mg} / 100 \mathrm{~g}\end{array}$ & $\begin{array}{c}1314.68 \pm 2.76 \mathrm{mg} / 100 \mathrm{~g} \\
13,227.41 \mathrm{mg} / \mathrm{kg} \text { dry powder } \\
969.12 \pm 19.31 \mathrm{mg} / 100 \mathrm{~g}\end{array}$ & $\begin{array}{l}{[73]} \\
{[80]} \\
{[40]}\end{array}$ \\
\hline Reducing sugar & $\begin{array}{c}58.37 \pm 1.54 \mathrm{mg} / 100 \mathrm{~g} \\
1.52 \pm 0.01 \mathrm{~g} / \mathrm{kg} \\
295.54 \pm 2.01 \mathrm{mg} / 100 \mathrm{~g} \\
5.9 \pm 0.8 \mathrm{~g} / \mathrm{kg} \mathrm{DM}\end{array}$ & $\begin{array}{c}394.52 \pm 3.29 \mathrm{mg} / 100 \mathrm{~g} \\
12.42 \pm 0.85-16.07 \pm 0.38 \mathrm{~g} / \mathrm{kg} \\
754.51 \pm 4.05-4726.04 \pm 15.74 \mathrm{mg} / 100 \mathrm{~g} \\
472.4 \pm 46.5 \mathrm{~g} / \mathrm{kg} \mathrm{DM}\end{array}$ & $\begin{array}{l}{[40]} \\
{[46]} \\
{[73]} \\
{[18]}\end{array}$ \\
\hline Total phenol & $\begin{array}{c}1000 \mu \mathrm{g} / \mathrm{g} \\
18 \mathrm{mg} \mathrm{GAE} / \mathrm{kg} \mathrm{DM} \\
89468.55 \\
\mathrm{mg} \mathrm{QE} / \mathrm{kg} \mathrm{dry} \mathrm{basis} \\
14 \mathrm{mg} \mathrm{GAE} / \mathrm{g} \\
15,200 \mathrm{mg} \mathrm{GAE} / \mathrm{kg} \\
5150 \mathrm{mg} \mathrm{GAE} / \mathrm{kg} \mathrm{DM}\end{array}$ & $\begin{array}{c}8200 \mu \mathrm{g} / \mathrm{g} \\
80-140 \mathrm{mg} \mathrm{GAE} / \mathrm{kg} \mathrm{DM} \\
101,328.71-157,312.77 \\
\mathrm{mg} \mathrm{QE} / \mathrm{kg} \text { dry basis } \\
\text { 20-60 mg GAE/g } \\
\text { 24,050 mg GAE/kg } \\
14,900 \mathrm{mg} \mathrm{GAE} / \mathrm{kg} \mathrm{DM}\end{array}$ & $\begin{array}{l}{[83]} \\
{[46]} \\
{[65]} \\
{[44]}\end{array}$ \\
\hline Total flavonoid & $\begin{array}{c}2348.65 \mathrm{mg} \mathrm{GAE} / \mathrm{kg} \text { dry basis } \\
3.22 \pm 0.07 \mathrm{mg} \mathrm{RE} / \mathrm{g} \\
30.03 \mathrm{mg} / \mathrm{kg} \mathrm{DM} \\
0.25 \mathrm{mg} / 100 \mathrm{~g} \\
0.20 \mathrm{mg} / 100 \mathrm{~g} \mathrm{FG} \text { water extract } \\
1.40 \mu \mathrm{g} \mathrm{CAE} / \mathrm{mg}\end{array}$ & $\begin{array}{c}3825.51-27,191.38 \mathrm{mg} \mathrm{GAE} / \mathrm{kg} \text { dry basis } \\
5.38 \pm 0.06-15.70 \pm 2.11 \mathrm{mg} \mathrm{RE} / \mathrm{g} \\
30-105 \mathrm{mg} / \mathrm{kg} \mathrm{DM} \\
0.70 \mathrm{mg} / 100 \mathrm{~g} \\
0.50 \mathrm{mg} / 100 \mathrm{~g} \mathrm{BG} \text { water extract } \\
1.92 \mu \mathrm{g} \mathrm{CAE} / \mathrm{mg}\end{array}$ & $\begin{array}{l}{[83]} \\
{[46]} \\
{[82]} \\
{[43]} \\
{[84]} \\
{[85]}\end{array}$ \\
\hline SAC & $\begin{array}{l}42.7 \mu \mathrm{g} / \mathrm{g} \mathrm{DM} \\
2.5 \mathrm{mg} / \mathrm{g} \mathrm{DW}\end{array}$ & $\begin{array}{c}656.5 \mu \mathrm{g} / \mathrm{g} \mathrm{DM} \\
8.05 \mathrm{mg} / \mathrm{g} \mathrm{DW} \\
95.07 \pm 1.84-427.05 \pm 3.56 \mu \mathrm{g} / \mathrm{g} \\
85.46 \pm 0.81-124.67 \pm 1.61 \mu \mathrm{g} / \mathrm{g} \\
242.3 \pm 6.1 \mu \mathrm{g} / \mathrm{g} \mathrm{DW} \\
19.4 \mathrm{mg} / 100 \mathrm{~g}\end{array}$ & $\begin{array}{l}{[86]} \\
{[87]} \\
{[88]} \\
{[16]} \\
{[89]} \\
{[90]}\end{array}$ \\
\hline 5-HMF & & $\begin{array}{c}0.25 \pm 0.04 \mathrm{~g} / \mathrm{kg} \mathrm{FM} \\
4.82 \pm 0.06 \mathrm{~g} / \mathrm{kg} \\
6-8 \mathrm{~g} / \mathrm{kg}\end{array}$ & $\begin{array}{l}{[65]} \\
{[41]} \\
{[42]}\end{array}$ \\
\hline Melanoidin & $<0.2$ OD FM & $\sim 2$ OD FM & [75] \\
\hline Ash & $\begin{array}{c}73.59 \pm 0.89 \mathrm{mg} / 100 \mathrm{~g} \\
0.92 \pm 0.62 \%\end{array}$ & $\begin{array}{c}75.36 \pm 0.02-114.36 \pm 8.65 \mathrm{mg} / 100 \mathrm{~g} \\
1.81 \pm 0.05 \%\end{array}$ & $\begin{array}{l}{[73]} \\
{[40]}\end{array}$ \\
\hline Volatile compounds & $49.76 \mu \mathrm{g} / \mathrm{g}$ & $39.04-100.46 \mu \mathrm{g} / \mathrm{g}$ & [83] \\
\hline Organic acid & $16.70 \pm 0.61 \mathrm{~g} / \mathrm{kg} \mathrm{DM}$ & $64.50 \pm 7.55 \mathrm{~g} / \mathrm{kg} \mathrm{DM}$ & [41] \\
\hline Alkaloid & Trace amount & 30-fold increase of FM & [91] \\
\hline Lipid & $\begin{array}{l}0.20 \pm 0.01 \% \\
0.1 \%\end{array}$ & $\begin{array}{l}0.60 \pm 0.11 \% \\
0.30 \%\end{array}$ & $\begin{array}{l}{[40]} \\
{[90]}\end{array}$ \\
\hline Carbohydrate & $30 \%$ & $50 \%$ & [90] \\
\hline
\end{tabular}


Table 2. Cont.

\begin{tabular}{|c|c|c|c|}
\hline Phytochemical & Total Content in Fresh Garlic & Total Content in Black Garlic & Ref. \\
\hline \multirow[b]{2}{*}{ Protein } & $0.9 \%$ & $1.2 \pm 0.1 \%$ & [40] \\
\hline & $8.4 \%$ & $9.5 \%$ & [90] \\
\hline Vitamin & $6632.91 \pm 18.62 \mathrm{mg} / \mathrm{kg}$ & $7618.24 \pm 28.47-9,010.44 \pm 30.61 \mathrm{mg} / \mathrm{kg}$ & [70] \\
\hline \multirow{2}{*}{ Pyruvate } & $19.01 \pm 0.3 \mathrm{mmol} / 100 \mathrm{~g}$ & $28.05 \pm 0.3 \mathrm{mmol} / 100 \mathrm{~g}$ & [40] \\
\hline & $49.05 \pm 1.2 \mathrm{mmol} / 100 \mathrm{~g}$ & $246.02 \pm 2.4 \mathrm{mmol} / 100 \mathrm{~g}$ & [20] \\
\hline Thiosufate & $6.50 \pm 0.29 \mu \mathrm{M} / \mathrm{g}$ & $91.22 \pm 0.54 \mu \mathrm{M} / \mathrm{g}$ & [20] \\
\hline
\end{tabular}

FG: fresh garlic; BG: black garlic; DM: dry matter; DW: dry weight; FM: fresh matter; GAE: gallic acid equivalent; QE: quercetin equivalent; RE: rutin equivalent; CAE: catechin equivalents; OD: optical density for an absorbance at $420 \mathrm{~nm}$.

During the production of BG by heating at $60-90^{\circ} \mathrm{C}$ for $10-15$ days, allicin was reduced by $70-80 \%$ [92]. This is because of the synthesis of allicin and the thermolysis process during the first two days. Alliin is particularly prone to deterioration due to its unstable sulfoxide bond at a high temperature. Zhang et al. [41] showed the level of alliin declined more quickly at $90{ }^{\circ} \mathrm{C}$ than 80,70 , and $60{ }^{\circ} \mathrm{C}$, respectively, after about $12,24,33$, and 66 days of incubation with nearly the same amount of allicin $(0.3 \mathrm{~g} / \mathrm{kg})$. Furthermore, Chen et al. [93] explored thermal alliin degradation over $50 \mathrm{~h}$ at $60-90^{\circ} \mathrm{C}$ and identified secondary organosulfur compounds in the HPLC-MS system, mainly including SAC, dialanine tetra-sulfide, di-alanine disulfide, allyl alanine disulfide, allyl alanine tetra-sulfide, allyl-alanine trisulfide, and di-alanine trisulfide. SAC is the major organosulfur molecule, which is generated by $\gamma$ - glutamyl-S-allyl cysteine (catalyzed by $\gamma$-GTP) during the enzyme hydrolysis [94]. Although $\gamma$-GTP activity might have a chance to be damaged by heating, Chen et al. [93] showed a technique to produce SAC from alliin by direct thermal processing even if $\gamma$-GTP was inactive. Recently, Al-Sheri et al. [86] reported $42.7 \mu \mathrm{g} / \mathrm{g}$ DM of SAC in fresh garlic extract and this value increased up to $656.5 \mu \mathrm{g} / \mathrm{g}$ DM in BG extract. According to Sasaki et al. [90], SAC contents increased over 8-fold in BG when compared with fresh garlic. Similarly, Park et al. [87] showed the SAC contents of about $2.5 \mathrm{mg} / \mathrm{g}$ dry weight (DW) in fresh garlic and the content increased to $8.05 \mathrm{mg} / \mathrm{g}$ DW after the aging process. In another study, Kim et al. [22] quantified the SAC contents of $73.5 \pm 12.5 \mu \mathrm{g} / \mathrm{g}$ DW in fresh garlic juice, while in BG juice it was $242.3 \pm 6.1 \mu \mathrm{g} / \mathrm{g}$ DW. In addition, Thao et al. [88] and Bae et al. [16] determined higher contents of SAC at a concentration of $124.67 \pm 1.61 \mu \mathrm{g} / \mathrm{g}$ and $427.05 \pm 3.56 \mu \mathrm{g} / \mathrm{g}$, respectively. On the other hand, allicin is a highly reactive compound with limited thermal stability. It decomposes into diallyl sulfide (DAS), diallyl disulfide, diallyl trisulfide, ajoene, and finally is transformed into S-allylmercapto-cysteine (SAMC). SAMC is an odor-free, tasteless, and stable molecule that is around 6-fold higher in BG than in fresh garlic [92]. SAMC production in BG is also associated with the $\gamma$-GTP enzyme which requires an optimum temperature of $40{ }^{\circ} \mathrm{C}$ for activity [16]. Therefore, complete inhibition of the $\gamma$-GTP enzyme during BG production is expected. Thus, these findings indicate that the rise in SAC concentration is primarily due to allicin conversion.

Regarding variations in total phenolic content, most of the studies agreed that total phenolic content would increase substantially in BG manufacturing so that the levels of BG polyphenols are multiple times higher than the level of fresh garlic. In a study, Kim et al. [82] demonstrated that the total phenolic contents of BG were found to be approximately 3- to 10-fold higher than fresh garlic and hydroxycinnamic acid derivatives were identified as the major phenolic acids in BG at various processing stages. Similarly, Toledano-Medina et al. [44] showed higher contents of total phenolic content in BG $(14,900 \mathrm{mg}$ GAE$/ \mathrm{kg} \mathrm{DM})$ which was approximately three times higher than fresh garlic. A similar higher tendency of phenolic contents in BG was also noted in the study of Li et al. [65], who reported 24,050 $\mathrm{mg}$ GAE/ $\mathrm{kg}$ of total phenolic content in BG. In addition, similar to polyphenols, the total flavonoid contents in BG may also fluctuate due to processing conditions. The total flavonoid content in BG was increased by 3- to 12-fold compared with 
that in fresh garlic and flavonols as well as flavonols were identified as major flavonoid compounds in BG [22,43,46,83-85].

Furthermore, Yang et al. [75] identified nine key aroma-active compounds in BG including acetic acid (sour), furaneol (caramel), allyl methyl trisulfide (cooked garlic), (E,Z)-2,6-nonadien1-ol (cucumber), diallyl disulfide (garlic), diallyl trisulfide (sulfur), 5heptyldihydro-2(3H)-furanone (apricot), 3-methylbutanoic acid (sweat), and diallyl sulfide (garlic) through aroma recombination and omission experiments. Moreover, several studies also reported a higher content of carbohydrates such as fructose, glucose, followed by tryptophan, valine, glycine, and arginine as the major amino acids, saponin, thiosulfate, and pyruvate $[18,20,73,76,92]$.

\section{Impact of Black Garlic on Health Promotion and Diseases Treatment}

BG and its derivatives have been documented to have multiple biological impacts on health promotion and treatment of various diseases. The transformation of fresh garlic to BG results in modifications in the biological activity of bioactive compounds caused by fermentation. In the past few decades, extensive pre-clinical investigations have shown the therapeutical potential of BG against a wide variety of human diseases. Furthermore, it has been demonstrated that BG interacts directly with a number of signaling molecules. These pre-clinical investigations have established a good foundation for clinical trials investigating BG's efficacy. The pre-clinical and clinical findings on the bioactive effects of curcumin are described briefly in the following sections.

\subsection{Effects of Black Garlic on Metabolic Disorders \\ 6.1.1. Black Garlic and Diabetes Mellitus}

Diabetes mellitus is a heterogeneous form of metabolic disorder characterized by chronic hyperglycemia with impaired carbohydrate, lipid, and protein metabolism resulting from defects in insulin secretion, insulin action, or both [95]. Clinical and experimental studies have demonstrated that chronic hyperglycemia is a major source of oxidative stress and that elevated free radicals play a key role in diabetes mellitus pathogenesis and complications. Several studies have investigated the anti-diabetic potential of BG and these studies described variable effects of BG on conventional diabetes mellitus markers (Table 3). For example, aged black garlic extract exhibited ameliorative action on glycometabolic biomarkers in streptozotocin-induced diabetic rats by significantly decreasing blood glucose, glycated hemoglobin, and markedly increased serum insulin. Additionally, aged garlic extract significantly attenuated the elevation of serum triglyceride, total cholesterol, and lowered lipid peroxidation in liver and kidney tissues [96]. A similar type of result was also reported in the study performed by Thomson et al. [97] and Seo et al. [30], where aged garlic extract reduced the oxidative stress markers, improved insulin sensitivity, dyslipidemia, and other complications of diabetes in male Sprague-Dawley rats and $\mathrm{C} 57 \mathrm{BL} / \mathrm{KsJ}-\mathrm{db} / \mathrm{db}$ mice, respectively. Another study examined the anti-diabetic effects of BG powder in male Wister rats and found that BG powder lowered blood glucose, prevented glycogen in the liver, and improved lipid metabolism by increasing the activity of glutamic oxaloacetic transaminase, glutamic pyruvic transaminase, and $\gamma$-GTP [98]. Moreover, Lee et al. [99] observed that aged garlic extract significantly decreased thiobarbituric acid reactive substances levels and elevated the activities of SOD, glutathione peroxidase (GSH-Px), and catalase (CAT) in diabetic mice. The results obtained by $\mathrm{Si}$ et al. [100] demonstrated that 40 weeks of supplementation of BG lowered the levels of plasma malondialdehyde, SOD, GSH-Px, and total antioxidant capacity in pregnant women. They also mentioned that Lactobacillus bulgaricus improved the antioxidant capacity of BG in the prevention of gestational diabetes mellitus. On the other hand, Kim et al. [89] used SAC-enriched BG juice and treated streptozotocin 239-induced insulin-deficient mice. The authors found that BG juice improved the glutathione antioxidant system, increased leptin, and adiponectin secretion, inhibited hepatic gluconeogenesis, and suppressed nuclear factor-kappa $\beta$ (NF- $\mathrm{k} \beta$ )-mediated inflammatory signaling. 
Table 3. Effects of black garlic on metabolic disorders.

\begin{tabular}{|c|c|c|c|c|c|}
\hline Diseases & Products & $\begin{array}{c}\text { Subjects/Cell } \\
\text { Line/Animal Model }\end{array}$ & Outcomes & Mode of Action & Ref. \\
\hline \multirow{7}{*}{$\begin{array}{l}\text { Diabetes } \\
\text { mellitus }\end{array}$} & $\begin{array}{c}\text { Black garlic juice } \\
\text { (BGJ) }\end{array}$ & Male C57BL/6J mice & $\begin{array}{l}\text { SAC-enriched BGJ } \\
\text { counteracted } \\
\text { STZ239-induced } \\
\text { diabetes and } \beta \text {-cell } \\
\text { failure in mice. }\end{array}$ & $\begin{array}{l}\text { Improved glutathione } \\
\text { antioxidant system, } \\
\text { increased leptin and } \\
\text { adiponectin secretion. } \\
\text { Inhibited hepatic } \\
\text { gluconeogenesis and } \\
\text { NF- } \kappa \text {-mediated } \\
\text { inflammatory signaling. }\end{array}$ & [89] \\
\hline & Aged garlic & $\begin{array}{l}\text { Male Sprague-Dawley } \\
\text { rats }\end{array}$ & $\begin{array}{l}\text { Ameliorated oxidative } \\
\text { stress and other } \\
\text { complications of } \\
\text { diabetes. }\end{array}$ & $\begin{array}{l}\text { Decreased body weight, } \\
\text { blood glucose, serum } \\
\text { cholesterol, triglycerides, } \\
\text { and fructosamine. }\end{array}$ & [97] \\
\hline & $\begin{array}{l}\text { Aged black garlic } \\
\text { (ABG) }\end{array}$ & $\begin{array}{l}\mathrm{C} 57 \mathrm{BL} / \mathrm{KsJ}-\mathrm{db} / \mathrm{db} \\
\text { mice }\end{array}$ & $\begin{array}{l}\text { ABG improved insulin } \\
\text { sensitivity and } \\
\text { dyslipidemia in } \mathrm{db} / \mathrm{db} \\
\text { mice. }\end{array}$ & $\begin{array}{l}\text { Decreased serum glucose, } \\
\text { total cholesterol, } \\
\text { triglyceride and increased } \\
\text { HDL-C levels. }\end{array}$ & [30] \\
\hline & $\begin{array}{c}\text { Black garlic } \\
\text { powder (BGP) }\end{array}$ & Male Wister rats & $\begin{array}{l}\text { BGP lowered blood } \\
\text { glucose, prevented } \\
\text { glycogen in the liver, } \\
\text { and improved lipid } \\
\text { metabolism. }\end{array}$ & $\begin{array}{l}\text { Lowered glycosylated } \mathrm{Hb} \text {, } \\
\text { and total cholesterol and } \\
\text { increased HDL-C. } \\
\text { BGP increased the activity } \\
\text { of GOT, GPT, } \gamma \text {-GTP in } \\
\text { serum. }\end{array}$ & [98] \\
\hline & $\begin{array}{l}\text { Aged black garlic } \\
\text { (ABG) }\end{array}$ & $\begin{array}{c}\mathrm{C} 57 \mathrm{BL} / \mathrm{KsL}-\mathrm{db} / \mathrm{db} \\
\text { mice }\end{array}$ & $\begin{array}{c}\text { ABG prevented } \\
\text { diabetic complications } \\
\text { through antioxidant } \\
\text { activity. }\end{array}$ & $\begin{array}{l}\text { Decreased TBARS levels, } \\
\text { elevated the activities of } \\
\text { SOD, GSH-Px, and CAT. }\end{array}$ & [99] \\
\hline & $\begin{array}{l}\text { Aged garlic (AG) } \\
\text { and } \\
\text { S-allyl cysteine } \\
\text { (SAC) }\end{array}$ & BSA or lysozyme & $\begin{array}{l}\text { AG + SAC prevented } \\
\text { the formation of } \\
\text { advanced glycation } \\
\text { end products. }\end{array}$ & & [107] \\
\hline & Aged garlic (AG) & Sprague-Dawley rats & $\begin{array}{l}\text { AG exhibited } \\
\text { ameliorative action on } \\
\text { indicators of diabetes. }\end{array}$ & $\begin{array}{l}\text { Decreased blood glucose, } \\
\text { GHb, and lipid } \\
\text { peroxidation. } \\
\text { Markedly increased serum } \\
\text { insulin, serum triglyceride } \\
\text { elevation, and total } \\
\text { cholesterol. }\end{array}$ & [96] \\
\hline \multirow[b]{2}{*}{ Obesity } & $\begin{array}{l}\text { Aged garlic } \\
\text { (AG) }\end{array}$ & $\begin{array}{l}51 \text { healthy adults with } \\
\text { obesity } \\
\text { Study period: } 6 \text { weeks }\end{array}$ & $\begin{array}{l}\text { AG prevented the } \\
\text { development of } \\
\text { chronic diseases } \\
\text { associated with } \\
\text { low-grade } \\
\text { inflammation. }\end{array}$ & $\begin{array}{l}\text { Decreased TNF- } \alpha, \text { IL-6, } \\
\text { blood LDL levels. }\end{array}$ & [104] \\
\hline & $\begin{array}{l}\text { Fermented garlic } \\
\text { by lactic acid } \\
\text { bacteria (FBLA) }\end{array}$ & Male C57BL/6J mice & $\begin{array}{l}\text { FBLA ameliorated } \\
\text { diet-induced obesity } \\
\text { by inhibiting adipose } \\
\text { tissue hypertrophy by } \\
\text { suppressing } \\
\text { adipogenesis. }\end{array}$ & $\begin{array}{c}\text { Reduced body weight, TG, } \\
\text { TC, retroperitoneal, } \\
\text { epididymal, and } \\
\text { mesenteric adipose tissue } \\
\text { mass. } \\
\text { Downregulated mRNA } \\
\text { protein expression of } \\
\text { PPAR } \gamma \text {, C/EBP } \alpha \text {, and } \\
\text { lipogenic proteins, } \\
\text { including SREBP-1c, FAS, } \\
\text { and SCD-1. }\end{array}$ & [102] \\
\hline
\end{tabular}


Table 3. Cont.

\begin{tabular}{|c|c|c|c|c|c|}
\hline Diseases & Products & $\begin{array}{c}\text { Subjects/Cell } \\
\text { Line/Animal Model }\end{array}$ & Outcomes & Mode of Action & Ref. \\
\hline & Aged garlic & $\begin{array}{c}\text { Male Sprague-Dawley } \\
\text { rats }\end{array}$ & $\begin{array}{l}\text { Modified the adipose } \\
\text { weight and improved } \\
\text { the oxidative stress. }\end{array}$ & $\begin{array}{l}\text { Decreased Body weight } \\
\text { gain, visceral, epididymal } \\
\text { fat, and TBARS levels. }\end{array}$ & [101] \\
\hline & Black garlic & Male Wister rats & $\begin{array}{c}\text { Ameliorated } \\
\text { diet-induced obesity } \\
\text { via regulating } \\
\text { adipogenesis, } \\
\text { adipokine } \\
\text { biosynthesis, and } \\
\text { lipolysis. }\end{array}$ & $\begin{array}{l}\text { Upregulated AMPK, } \\
\text { FOXO1, Sirt1, ATGL, HSL, } \\
\text { perilipin, ACO, CPT-1, } \\
\text { UCP1, adiponectin, and } \\
\text { PPAR } \alpha \text {. Downregulated } \\
\text { CD36, SREBP-1c, ACC, } \\
\text { FAS, and SCD1. }\end{array}$ & [105] \\
\hline & Aged garlic & Sprague Dawley rats & $\begin{array}{c}\text { Exhibited anti-obesity, } \\
\text { cholesterol-lowering, } \\
\text { and anti-inflammatory } \\
\text { effects. }\end{array}$ & $\begin{array}{l}\text { Reduced body weight, } \\
\text { visceral fat, liver weight, } \\
\text { total cholesterol, } \\
\text { low-density lipoprotein, } \\
\text { and C-reactive protein. }\end{array}$ & [103] \\
\hline & $\begin{array}{l}\text { Aged black } \\
\text { garlic }\end{array}$ & $\begin{array}{c}\text { Male Sprague-Dawley } \\
\text { rats }\end{array}$ & $\begin{array}{l}\text { Improved the body } \\
\text { weight gain and } \\
\text { dyslipidemia through } \\
\text { the suppression of } \\
\text { body fat and alteration } \\
\text { in lipid profiles and } \\
\text { antioxidant defense } \\
\text { system. }\end{array}$ & $\begin{array}{l}\text { Decreased the body } \\
\text { weight, adipose tissue } \\
\text { weight, TC, TG, and } \\
\text { increased oxidized GSH } \\
\text { and LPO in the serum. }\end{array}$ & [29] \\
\hline & Black garlic (BG) & Male Wister rats & $\begin{array}{c}\text { BG ameliorated } \\
\text { obesity induced by a } \\
\text { HFD in rats. }\end{array}$ & $\begin{array}{l}\text { Decreased body weight, } \\
\text { tissue weight of liver, } \\
\text { epididymal fat, peritoneal } \\
\text { fat, serum triglycerides, } \\
\text { hepatic lipid profile, } \\
\text { GSSG, and enhanced } \\
\text { TEAC, GSH, GRd, and } \\
\text { GPx. }\end{array}$ & [25] \\
\hline & $\begin{array}{l}\text { Aged black } \\
\text { garlic }\end{array}$ & $3 \mathrm{~T} 3-\mathrm{L}_{1}$ preadipocytes & $\begin{array}{l}\text { Exhibited } \\
\text { anti-lipogenic and } \\
\text { lipolytic effects. }\end{array}$ & $\begin{array}{c}\text { Reduced protein } \\
\text { expression of PPAR } \gamma \\
\text { HSL, and Ser-pHSL levels. }\end{array}$ & [106] \\
\hline
\end{tabular}

SAC: s-allyl cysteine; NF- $\kappa \beta$ : nuclear factor- $\kappa \beta$; HDL-C: high-density lipoprotein cholesterol; GOT: glutamic oxaloacetic transaminase; GPT: glutamic pyruvic transaminase; $\gamma$-GTP: $\gamma$ - glutamyl transpeptidase; SOD: superoxide dismutase; GSH-Px: glutathione peroxidase; CAT: catalase; GHb: glycated hemoglobin; STZ: streptozotocin; TBARS: thiobarbituric acid reactive substances; TNF- $\alpha$ : tumor necrosis factor- $\alpha$; IL-6: interleukin-6; LDL: low density lipoprotein; TG: triglyceride; TC: total cholesterol; mRNA: messenger ribonucleic acid; $\mathrm{C} / \mathrm{EBP} \alpha$ : CCAAT/enhancer-binding protein $\alpha$; UCP1: uncoupling protein 1; CPT-1: carnitine palmitoyl transferase 1; ACO: acyl-coenzyme A oxidase; HSL: hormone sensitive lipase; ATGL: adipose triglyceride lipase; Sirt1: sirtuin 1; FOXO1: forkhead box O1; PPAR $\alpha$ : peroxisome proliferator-activated receptor $\alpha$; AMPK: AMP-activated protein kinase; SREBP-1c: sterol regulatory element binding protein-1c; ACC: acetyl-CoA carboxylase; FAS: fatty acid synthase; SCD1: stearoyl-CoA desaturase-1; HFD: high fat diet; LPO: lipid peroxidation; GSSG: glutathione disulfide; TEAC: trolox equivalent antioxidant capacity; GSH: glutathione; GRd: glutathione reductase; GPx: glutathione peroxidase; PPAR $\gamma$ : proliferator activated receptor $\gamma$; Ser-pHSL: serum-phosphorylated HSL.

\subsubsection{Black Garlic and Obesity}

Obesity has become a major public health problem. Obesity-related problems are linked to a variety of metabolic syndrome symptoms including high blood pressure, dyslipidemia, insulin resistance, and glucose intolerance. Various approaches might be employed in human obesity prevention and control. Since a perfect cure or prevention of obesity still remains to be established and the majority of the anti-obesity drugs could have adverse effects, an exploration into the identification of new materials has shown a growing interest. BG extracts have been reported for their activity in reducing body weight, adipose tissue mass, serum triglyceride, total cholesterol, low-density lipoprotein, and plasma malondialdehyde in mice with high-fat-diet-induced obesity (Table 3$)[25,29,101]$. The fermentation 
of garlic by lactic acid bacteria ameliorated diet-induced obesity in $\mathrm{db} / \mathrm{db}$ C57BL/6J mice by decreasing body weight $(18 \%)$, lowered epididymal (36\%), retroperitoneal $(44 \%)$, and mesenteric adipose tissue mass (63\%), respectively. Moreover, fermented garlic extract by lactic acid bacteria also downregulated mRNA protein expression of proliferator-activated receptor $\gamma(\operatorname{PPAR} \gamma)$, CCAAT-enhancer-binding proteins, and lipogenic proteins, including sterol-regulatory element-binding protein-1C (SREBP-1C), fatty acid synthase (FAS), and stearoyl-CoA desaturase-1 (SCD-1) [102]. Similarly, in another study, Seo et al. [103] proposed a mechanism underlying the anti-obesity function of aged garlic, which was closely related to upregulate adiponectin, peroxisome proliferator-activated receptor $\alpha$, and downregulate SREBP-1C, acetyl-CoA-carboxylase, FAS, and SCD1 in high-fat-diet mice. $X u$ et al. [104] carried out a clinical trial on 51 healthy adults for 6 weeks to investigate the effect of aged garlic extract on chronic inflammation and immune function in adults with obesity. A daily dose of $3.6 \mathrm{~g}$ aged garlic extract prevented the increase of serum tumor necrosis factor $\alpha$ (TNF- $\alpha$ ), interleukin-6 (IL-6), and reduced the levels of blood low-density lipoprotein in adult obesity. Moreover, Chen et al. [105] revealed that methanolic extract of BG ameliorated diet-induced obesity in male Wister rats via upregulate AMP-activated protein kinase, Forkhead box O1, sirtuin 1, adipose triglyceride lipase, hormone-sensitive lipase (HSL), perilipin, acyl-coenzyme A oxidase, carnitine palmitoyl transferase 1, uncoupling protein 1, and downregulated CD36 in the adipose tissue. Aged black garlic extract has also been reported to show anti-lipogenic and lipolytic effects in mature $3 \mathrm{~T}_{3}-\mathrm{L}_{1}$ adipocytes by reducing protein expression of PPAR $\gamma, \mathrm{HSL}$, and serum-phosphorylated HSL levels [106].

\subsection{Effects of Black Garlic on Genitourinary Tract Diseases}

BG has also demonstrated an intriguing capacity to alleviate symptoms associated with a variety of genitourinary diseases. Only a few research have examined the role of aged garlic extract in the treatment of kidney disorders, more precisely those caused by glomerular, tubulo-interstitial, or infectious pathologies (Table 4). In 2003, Maldonado et al. [108] demonstrated the effects of aged garlic extracts on gentamicin-induced nephrotoxicity in male Wister rats. It was found that aged garlic extract prevented gentamicin-induced nephrotoxicity by decreasing the oxidative stress and preserving the activities of manganese superoxide dismutase, glutathione peroxidase (GPx), and glutathione reductase (GR). In the case of diabetic nephropathy disease, aged garlic extract significantly decreased albumin levels in urine, blood urea nitrogen contents, and increased urine urea nitrogen contents in diabetic rats. The protective effect of aged garlic extract on diabetic nephropathy may be due to its anti-glycation and hypolipidemic effects [109]. Albrakati et al. [110] studied the effect of the aged black extract on chronic kidney disease and found that aged garlic extract rescued ethephon-induced kidney damage through the activation of nuclear factor erythroid 2-related factor 2 and inhibition of inflammation and apoptotic response. Another study performed by Lee et al. [111], on acute kidney injury in rats, showed very promising results when treated with aged black garlic extract. Treatment with aged black garlic extract prevented deterioration of renal function monitored by standardized biomarkers such as the serum levels of creatinine and blood urea nitrogen. Levels of oxidative stress markers such as 8-hydroxydeoxyguanosine, malondialdehyde, $\mathrm{NF}-\kappa \beta$, inducible nitric oxide (NO) synthase, cyclooxygenase-2 (COX-2), and transforming growth factor-beta 1 (TGF- $\beta 1$ ) were lower in the aged black garlic. 
Table 4. Effects of black garlic on genitourinary tract diseases.

\begin{tabular}{|c|c|c|c|c|c|}
\hline Diseases & Products & $\begin{array}{l}\text { Subjects/Cell } \\
\text { Line/Animal } \\
\text { Model }\end{array}$ & Outcomes & Mode of Action & Ref. \\
\hline Nephrotoxicity & Aged garlic (AG) & Male Wister rats & $\begin{array}{l}\text { AG prevented } \\
\text { gentamicin-induced } \\
\text { nephrotoxicity. }\end{array}$ & $\begin{array}{c}\text { Decreased the oxidative } \\
\text { stress and preserved the } \\
\text { activities of } \\
\text { Mn-SOD, GPx, and GR }\end{array}$ & [108] \\
\hline $\begin{array}{l}\text { Diabetic } \\
\text { nephropathy } \\
\text { (DNP) }\end{array}$ & Aged garlic (AG) & Albino Wistar rats & $\begin{array}{l}\text { AG significantly } \\
\text { decreased albumin } \\
\text { levels in urine, blood } \\
\text { urea nitrogen contents, } \\
\text { and increased urine } \\
\text { urea nitrogen contents. }\end{array}$ & $\begin{array}{l}\text { The protective effect of AG } \\
\text { on DNP due to its } \\
\text { anti-glycation, } \\
\text { hypolipidemic effects. }\end{array}$ & [109] \\
\hline Kidney damage & $\begin{array}{l}\text { Aged } \\
\text { garlic } \\
(\mathrm{AG})\end{array}$ & Albino Wistar rats & $\begin{array}{c}\text { AG rescued } \\
\text { ethephon-induced } \\
\text { kidney } \\
\text { damage. }\end{array}$ & $\begin{array}{l}\text { Activation of Nrf2 and } \\
\text { inhibition of inflammation } \\
\text { and apoptotic } \\
\text { response. }\end{array}$ & [110] \\
\hline Kidney injury & $\begin{array}{l}\text { Aged } \\
\text { black garlic } \\
(\mathrm{ABG})\end{array}$ & $\begin{array}{l}\text { Male } \\
\text { Sprague-Dawley } \\
\text { rats }\end{array}$ & $\begin{array}{l}\text { ABG ameliorated } \\
\text { colistin-induced acute } \\
\text { kidney injury in rats. }\end{array}$ & $\begin{array}{c}\text { Reduced the levels of } \\
\text { oxidative stress biomarkers } \\
\text { such as } \\
\text { 8-hydroxydeoxyguanosine } \\
\text { and malondialdehyde. } \\
\text { Lowered the levels of } \\
\text { NF- } \kappa \beta \text {, inducible NO } \\
\text { synthase, COX-2, and } \\
\text { TGF- } \beta 1 \text {, and also restored } \\
\text { SOD, CAT, and GSH levels. }\end{array}$ & [111] \\
\hline
\end{tabular}

Mn-SOD: manganese superoxide dismutase; GPx: glutathione peroxidase; GR: glutathione reductase; Nrf2: nuclear factor-erythroid factor 2-related factor 2; NF- $\kappa \beta$ : nuclear factor- $\kappa \beta$; NO: nitric oxide; COX-2: cyclooxygenase-2; TGF- $\beta 1$ : transforming growth factor beta 1; SOD: superoxide dismutase; CAT: catalase; GSH: glutathione.

\subsection{Effects of Black Garlic on Digestive Diseases \\ 6.3.1. Black Garlic and Liver Diseases}

Numerous substances, including dietary components, drugs, alcohols, and pollutants, can cause acute and/or chronic liver diseases, such as liver fibrosis, non-alcoholic liver disease, non-alcoholic steatohepatitis, and even cirrhosis. BG has been widely investigated for its hepatoprotective properties (Table 5). In Wister rats with $\mathrm{CCl}_{4}$-induced liver injury, the administration of BG extract was found to show a hepatoprotective effect based on the protection against oxidative damage. The levels of SOD, GSH-Px were decreased with an increase in the levels of alanine transaminase (ALT), aspartate transaminase (AST), lactate dehydrogenase, and alkaline phosphatase (ALP) [112]. In another study, Tsai et al. [28] demonstrated that the administration of SAC and polysaccharides enriched-BG extract into ICR mice inhibited $\mathrm{CCl}_{4}$-induced hepatic injury by inhibiting lipid peroxidation and inflammation. Moreover, Kim et al. [113] demonstrated the hepatoprotective effects of aged black garlic on chronic-induced liver injury in Sprague-Dawley rats due to the suppressive effects of aged black garlic extract on cytochrome P450 2E1 activity and its inductive effect on glutathione-s-transferase and quinone reductase activities. Shin et al. [27] reported that the administration of aged black garlic extract lowered the AST and ALT levels in the liver of Sprague-Dawley rats treated with $\mathrm{CCl}_{4}$ and D-galactosamine, consequently protecting the liver. The hepatoprotective effects of fermented garlic extract were also confirmed in the two different studies carried out by Jiang et al. [114] and Chung et al. [26], where the administration of fermented BG extract into C57BL/ 6 mice modulated glycometabolism, lipometabolism, oxidative stress, and inflammation. Therefore, BG may be a promising agent to prevent oxidative stress and cholesterol-related liver disorders, by decreasing the 
levels of ALT, AST, ALP, total cholesterol, low-density lipoprotein-cholesterol (LDL-C), and malondialdehyde, increasing SOD, GSH-Px, CAT, GPx, and GR. Furthermore, Lee et al. [115] showed that lactic acid-fermented garlic extracts protected against oxidative liver injury by acetaminophen through inhibiting apoptosis, maintaining cellular GSH, and protecting from oxidative damage to mitochondria as well as suppressing liver mitogenactivated protein kinases (MAPKs) activation.

Table 5. Effects of black garlic on digestive disorders.

\begin{tabular}{|c|c|c|c|c|c|}
\hline Diseases & Products & $\begin{array}{l}\text { Subjects/Cell } \\
\text { Line/Animal } \\
\text { Model }\end{array}$ & Outcomes & Mode of Action & Ref. \\
\hline \multirow{7}{*}{ Liver } & Aged garlic & C57BL/6 mice & $\begin{array}{l}\text { Modulation of } \\
\text { glycometabolism, } \\
\text { lipometabolism, } \\
\text { oxidative stress, and } \\
\text { inflammation. }\end{array}$ & $\downarrow$ ALT, AST, TC, LDL-C, MDA & [114] \\
\hline & $\begin{array}{c}\text { Black } \\
\text { garlic (BG) }\end{array}$ & Wister rats & $\begin{array}{l}\text { BG protected against } \\
\text { oxidative damage caused by } \\
\mathrm{CCl}_{4} \text {-induced liver injury. }\end{array}$ & $\begin{array}{c}\text { SOD, GSH-Px } \\
\text { ALT, AST, LDH, } \\
\text { and ALP }\end{array}$ & [112] \\
\hline & $\begin{array}{l}\text { Lactic acid- } \\
\text { fermented } \\
\quad \text { garlic }\end{array}$ & Wister rats & $\begin{array}{c}\text { Protected against } \\
\text { oxidative liver injury. }\end{array}$ & $\begin{array}{c}\text { ALP, AST, and ALT } \\
\text { ATP depletion } \\
\text { TNF- } \alpha, \text { IL-1 } \beta \\
\text { Apoptosis } \\
\text { (BCL-2, Bax } \\
\text { Cascape-3) }\end{array}$ & [115] \\
\hline & $\begin{array}{l}\text { Fermented } \\
\text { black } \\
\text { garlic }\end{array}$ & C57BL/6J mice & $\begin{array}{c}\text { Improved the effects on fatty } \\
\text { liver. }\end{array}$ & $\mid \begin{array}{c}\text { AST, ALT } \\
\text { Total cholesterol, } \\
\text { LDL/V-LDL- } \\
\text { cholesterol, } \\
\text { triglyceride contents }\end{array}$ & [26] \\
\hline & Black garlic & ICR mice & $\begin{array}{l}\text { Inhibited } \mathrm{CCl}_{4} \text {-induced } \\
\text { hepatic injury by inhibiting } \\
\text { lipid peroxidation } \\
\text { and inflammation. }\end{array}$ & $\begin{array}{c}\downarrow \text { ALT, AST, ALP, and MDA } \\
\quad \downarrow \text { TNF- } \alpha \text { and IL-1 } \beta \\
\\
4 \text { SOD, GSH-Px, GSH-Rd }\end{array}$ & [28] \\
\hline & $\begin{array}{l}\text { Aged black } \\
\text { garlic }\end{array}$ & $\begin{array}{l}\text { Sprague- } \\
\text { Dawley } \\
\text { rats }\end{array}$ & $\begin{array}{l}\text { Exhibited protective } \\
\text { effects against chronic } \\
\text { alcohol-induced liver } \\
\text { damage. }\end{array}$ & $\begin{array}{c}\text { AST, ALT, ALP, } \\
\text { and LDH } \\
\text { 4 GSH-Px, GR, and } \\
\text { CAT }\end{array}$ & [113] \\
\hline & $\begin{array}{l}\text { Aged black } \\
\text { garlic }\end{array}$ & $\begin{array}{l}\text { Sprague- } \\
\text { Dawley rats }\end{array}$ & $\begin{array}{l}\text { Showed hepatoprotective } \\
\text { effects against liver injury. }\end{array}$ & $\begin{array}{l}\downarrow \text { AST, and ALT } \\
\text { No effects on ALP. }\end{array}$ & [27] \\
\hline \multirow{3}{*}{ Inflammatory } & $\begin{array}{l}\text { Aged black } \\
\text { garlic }\end{array}$ & RAW 264.7 cells & $\begin{array}{l}\text { Suppressed the expression of } \\
\text { classical mitogen-activated } \\
\text { protein kinases (MAPKs) } \\
\text { (ERK1/2 and p38 MAPK) in } \\
\text { LPS-stimulated macrophage } \\
\text { cells. }\end{array}$ & $\mid \begin{array}{c}\mathrm{NO}, \\
\text { prostaglandin E2 } \\
\text { IL-6, TNF- } \alpha, \text { IL-1 } \beta \\
\text { iNOS, COX-2 }\end{array}$ & [22] \\
\hline & $\begin{array}{l}\text { Aged black } \\
\text { garlic }\end{array}$ & U-937 cells & $\begin{array}{l}\text { Inhibited expression of } \\
\text { COX-2 and production of } \\
\text { prostaglandin E2. }\end{array}$ & Inactivation of $N F-k \beta$. & [116] \\
\hline & $\begin{array}{l}\text { Aged black } \\
\text { garlic }\end{array}$ & HES cells & $\begin{array}{l}\text { Reduced cell proliferation } \\
\text { and attenuated the } \\
\text { expression of ICAM-1 and } \\
\text { VCAM-1. }\end{array}$ & $\begin{array}{l}\text { Inhibition of the ERK, JNK } \\
\text { signaling pathways, ROS } \\
\text { formation, NF- } \kappa \beta \text {, and AP-1 } \\
\text { transcription factors. }\end{array}$ & [119] \\
\hline
\end{tabular}


Table 5. Cont.

\begin{tabular}{|c|c|c|c|c|c|}
\hline \multirow[t]{5}{*}{ Diseases } & Products & $\begin{array}{l}\text { Subjects/Cell } \\
\text { Line/Animal } \\
\text { Model }\end{array}$ & Outcomes & Mode of Action & Ref. \\
\hline & $\begin{array}{l}\text { Aged black } \\
\text { garlic }\end{array}$ & $\begin{array}{l}\text { RAW } 264.7 \\
\text { macrophages }\end{array}$ & $\begin{array}{c}\text { Exerted } \\
\text { anti-inflammatory effects. }\end{array}$ & $\begin{array}{c}\mathrm{NO}, \mathrm{TNF}-\alpha, \\
\text { prostaglandin E2 }\end{array}$ & [120] \\
\hline & $\begin{array}{l}\text { Fermented } \\
\text { black garlic }\end{array}$ & RAW 264.7 cells & $\begin{array}{c}\text { Exhibited anti-inflammatory } \\
\text { effects. }\end{array}$ & $\begin{array}{l}\text { NO, TNF- } \alpha \text {, } \\
\text { prostaglandin E2 } \\
\text { IL-1 } \beta, \text { IL-6 }\end{array}$ & {$[21]$} \\
\hline & 5-HNF & RAW 264.7 cells & $\begin{array}{c}\text { Exerted } \\
\text { anti-inflammatory effects. }\end{array}$ & $\begin{array}{l}\text { Inhibition of MAPK, NF- } \mathrm{\beta} \beta \text { and } \\
\text { Akt/mTOR pathways. }\end{array}$ & [118] \\
\hline & 5-HNF & HUVE cells & $\begin{array}{l}\text { Prevented TNF- } \alpha \text {-induced } \\
\text { monocytic cell adhesion to } \\
\text { HUVE cells. }\end{array}$ & $\begin{array}{l}\text { Suppressed vascular cell } \\
\text { adhesion molecule-1 } \\
\text { expression, reactive oxygen } \\
\text { species generation and } \\
\text { NF-к } \beta \text { activation. }\end{array}$ & [117] \\
\hline $\begin{array}{l}\text { Gastro- } \\
\text { intestinal } \\
\text { motility }\end{array}$ & Black garlic & $\begin{array}{l}\text { Sprague- } \\
\text { Dawley } \\
\text { rats }\end{array}$ & $\begin{array}{c}\text { Effectively promoted } \\
\text { gastrointestinal motility and } \\
\text { defection. }\end{array}$ & $\begin{array}{l}\text { Stimulated gastrointestinal } \\
\text { peristalsis, enhanced } \\
\text { gastrointestinal tract } \\
\text { emptying, and promoted } \\
\text { defecation. }\end{array}$ & [121] \\
\hline $\begin{array}{l}\text { Laxative } \\
\text { effects }\end{array}$ & $\begin{array}{l}\text { Mixed black } \\
\text { garlic } \\
\text { beverage }\end{array}$ & BALB/c mice & $\begin{array}{l}\text { Exhibited an obvious } \\
\text { laxative effect, which } \\
\text { improved the intestinal flora } \\
\text { of mice. }\end{array}$ & $\begin{array}{l}\text { Showed a relatively high } \\
\text { ink-propelling rate, increased } \\
\text { defection time, E. coli and } \\
\text { Enterococci. }\end{array}$ & [122] \\
\hline $\begin{array}{l}\text { Gastroesopha- } \\
\text { geal reflux } \\
\text { disease }\end{array}$ & Black garlic & $\begin{array}{l}\text { Sprague- } \\
\text { Dawley rats }\end{array}$ & $\begin{array}{l}\text { Showed protective effect on } \\
\text { reflux esophagitis. }\end{array}$ & $\begin{array}{ll}4 & \text { SOD, CAT } \\
\downarrow & \text { TNF- } \alpha, \text { IL- } 6\end{array}$ & [123] \\
\hline $\begin{array}{l}\text { Gastric } \\
\text { ulcer }\end{array}$ & $\begin{array}{l}\text { Aged } \\
\text { garlic }\end{array}$ & $\begin{array}{l}\text { Male Wistar } \\
\text { rats }\end{array}$ & $\begin{array}{l}\text { Prevented the } \\
\text { indomethacin-induced } \\
\text { ulcer. }\end{array}$ & $\begin{array}{c}\text { Reduced oxidative stress. } \\
\text { Increased gastric levels of PGE2, } \\
\text { GSH, and NO. }\end{array}$ & [124] \\
\hline $\begin{array}{l}\text { Gastric } \\
\text { damage }\end{array}$ & $\begin{array}{l}\text { Aged } \\
\text { garlic }\end{array}$ & $\begin{array}{c}\text { Male } \\
\text { albino rats }\end{array}$ & $\begin{array}{l}\text { Heal the gastric mucosal } \\
\text { injury induced by } \\
\text { indomethacin. }\end{array}$ & $\downarrow \begin{array}{c}\downarrow \\
\text { 个 } \\
\mathrm{tGSH}, \mathrm{SOD}, \mathrm{CAT}\end{array}$ & [125] \\
\hline $\begin{array}{l}\text { Intestinal } \\
\text { damage }\end{array}$ & $\begin{array}{l}\text { Aged } \\
\text { garlic }\end{array}$ & $\begin{array}{l}\text { Male Wistar } \\
\text { albino rats }\end{array}$ & $\begin{array}{l}\text { Reduced Intestinal } \\
\text { damaged induced by anti- } \\
\text { tumor drug methotrexate in } \\
\text { the small intestine. }\end{array}$ & $\begin{array}{l}\text { Aged garlic halted the MDA } \\
\text { increase in tissue and plasma } \\
\text { lactate elevations. Thus, } \\
\text { protected intestinal damage by } \\
\text { preserving cellular integrity. }\end{array}$ & [126] \\
\hline
\end{tabular}

AST: aspartate transaminase; ALT: alanine transaminase; TC: total cholesterol; LDL-C: low-density lipoprotein-cholesterol; SOD: superoxide dismutase; GSH-Px: glutathione peroxidase; LDH: lactate dehydrogenase; ALP: alkaline phosphatase; ATP: adenosine triphosphate; TNF- $\alpha$ : tumor necrosis factor; IL-1 $\beta$ : interleukin-1 $\beta$; BCL-2: B-cell lymphoma 2; Bax: BCL-2-associated X protein; MDA: malondialdehyde; CAT: catalase; GR: glutathione reductase; MAPK: mitogen-activated protein kinase; LDL/V-LDL: low density lipoprotein/very-low-density lipoprotein; GSH-Rd: glutathione reductase; IL-6: interleukin-6; ERK: extracellular-signal-regulated kinase; JNK: c-Jun N-terminal kinase; NO: nitric oxide; LPS: lipopolysaccharides; VCAM-1: vascular cell adhesion protein-1; ICAM-1: intercellular adhesion molecule-1; COX-2: cyclooxygenase-2; iNOS: inducible nitric oxide synthase; AP-1: activator protein-1; NF- $\kappa \beta$ : nuclear factor- $\kappa \beta$; PGE2: prostaglandin E2; GSH: glutathione; MPO: myeloperoxidase; tGSH: total glutathione.

\subsubsection{Black Garlic and Inflammatory Diseases}

Numerous in vitro investigations have demonstrated that BG has significant potential for treating a variety of diseases related to inflammation such as lethal sepsis, endometriosis, rheumatoid arthritis, inflammatory bowel diseases, etc. (Table 5). In lipopolysaccharide (LPS)-induced RAW 264.7 cells, the isolated 2-linoleoylglycerol from aged garlic was found to be capable of reducing the levels of NO, inflammatory mediators such as IL-6, TNF- $\alpha$, 
and interleukin-1 $\beta$, prostaglandin E2 as well as the expression of COX-2 and inducible nitric oxide synthase (iNOS). In this context, the anti-inflammatory action of aged garlic extract is most likely to suppress the expression of classical MAPKs (extracellular-signalregulated kinase (ERK) and p38 MAPK) [22]. A similar type of results was also reported by Park et al. [116], who observed that aged garlic extract inhibited the expression of COX-2 and prostaglandin E2 production by phorbol 12-myristate-13 acetate through inactivation of NF- $\kappa \beta$ in the human pre-monocytic cell model (U937). Kim et al. [117] reported that 5HNF isolated from aged black garlic prevented TNF- $\alpha$-induced monocytic cell adhesion to human umbilical vein endothelial cells (HUVECs) via suppression of vascular cell adhesion molecule-1 (VCAM-1) expression, reactive oxygen species generation (ROS), and NF- $\mathrm{k} \beta$ activation. In another study, 5-HNF exerted anti-inflammatory activity in RAW 264.7 cells against LPS-induced inflammatory response through inactivation of MAPKs, NF- $\mathrm{k} \beta$, and intracellular signaling Akt/m TOR pathway [118]. In vitro, a hexane extract of aged black garlic inhibited cell proliferation and cell cycle progression in TNF- $\alpha$ activated human endometrial stromal cells through the downregulation of ICAM- 1 and VCAM- 1 expression and IL- 6 secretion by inhibiting the activation of NF- $\mathrm{k} \beta$, ROS formation, activator protein-1 and the ERK as well as c-Jun N-terminal kinase signaling pathways [119]. In RAW 264.7 macrophages, it was shown that the anti-inflammatory effects of aged black garlic may be due to the inhibition of MAPKs, NF- $\kappa \beta$ activities, cytokine production, and expression of iNOS and COX-2 [21,120].

\subsubsection{Black Garlic and Other Gastrointestinal Diseases}

BG is a long-term dietary and medicinal supply capable of regulating the gastrointestinal system and promoting digestion. BG polysaccharide has been reported to show great potential in promoting gastrointestinal health benefits (Table 5). Chen et al. [121] recently evaluated the effect of BG extract on gastrointestinal motility. Results showed that in vitro, the BG n-butanol fraction extract exerted a substantially more significant impact in the small intestine. In addition, an increase in the levels of 5-hydroxytryptamine receptor 4 was efficient in stimulating gastrointestinal peristalsis, enhancing the emptiness of its gastrointestinal tract and defect promotion. Very few have studies investigated the laxative effects of BG. Li et al. [122] prepared a mixed BG beverage and the administration of high, medium, and low-dose BG beverage into BALB/c mice demonstrated that mixed BG beverage improved the intestinal flora of mice. The authors of this study concluded that a medium dose of mixed black garlic beverage showed a relatively high ink-propelling rate with less defection time in comparison with the negative group. Besides, the amounts of E. coli and Enterococci slightly increased but Lactobacillus had a significant difference before and after stomach perfusion. Recent studies reported that BG can be used therapeutically for inflammation-based gastroesophageal reflux disease including reflux esophagitis. Kim et al. [123] conducted a study to evaluate the protective effect of SAC-enriched BG on reflux esophagitis (RE) in Sprague-Dawley rats. BG was given an oral dose of $100 \mathrm{mg} / \mathrm{kg}$ body weight two hours before RE induction and its effects were compared to those of raw garlic. The authors of this study found that BG, rather than raw garlic, significantly inhibited RE-induced histological changes. The reduced catalase was dramatically increased by BG supplementation; nevertheless, levels of SOD tended to increase in the esophagus. These results suggested that $\mathrm{BG}$ treatment can ameliorate the development of esophagitis via regulation of NF- $\kappa \beta$ mediated inflammation. In addition, BG showed to be effective in the treatment of gastric ulcers, where it has been reported that after aged garlic extract $(200 \mathrm{mg} / \mathrm{kg})$ administration in male Wistar rats for 10 consecutive days, oxidative stress, as well as gastric levels of prostaglandin E2, GSH, and NO, were markedly decreased [124]. However, the study by Badr et al. [125] reported a possible mechanism of gastroprotective effects of the aged garlic extract against gastric damage induced by indomethacin in male albino rats, due to BG's anti-inflammatory actions and antioxidant properties, which released malondialdehyde levels and myeloperoxidase activity and increased total glutathione, SOD, and CAT activities. Similarly, aged garlic extract reduced the intestinal 
damage of male Wister rats, which was induced by the anti-tumor drug methotrexate. The aged garlic extract suppressed the increase in malondialdehyde in tissue and plasma lactate levels. Thus, aged garlic extract protected against intestinal injury by maintaining cellular integrity [126].

\subsection{Effects of Black Garlic on Cardiovascular System Diseases}

6.4.1. Black Garlic and Platelet Aggregation

The activation of blood platelets plays a vital role in many important physiological and pathological processes, including various arterial phenomena, such as myocardial infarction and strokes [127]. The platelets bind to the exposed collagen, laminin, and von Willebrand factor in the injured vessel wall, referred to as platelet activation. Adenosine-5diphosphate (ADP) and thrombin can also process the activation. The activated platelets change their shape, remove pseudopodia, release granules, and adhere to other platelets, thus commencing the platelet aggregation process. Platelet-activating factor, a cytokine released by neutrophils, monocytes, and platelets, also promotes aggregate formation [128]. Several studies have shown that BG has great potential in inhibiting platelet aggregation (Table 6). Pre-treatment of male Wister rats with aged garlic extracts significantly inhibited the platelet's ability to aggregate substantially and this effect was noticed on the fourteenth day. Additionally, aged garlic treatment resulted in platelets that responded to collagen by considerably raising both extracellular adenosine triphosphate (ATP) and intra- and extracellular thromboxane B2 levels. Furthermore, aged garlic extract treatment inhibited the phosphorylation of collagen-induced ERK, JNK, and p38 in a dose-dependent manner [129]. Fermented garlic is also effective in the inhibition of hypercholesterolemia and platelet aggregation. It was observed that the oral administration of fermented garlic $(300 \mathrm{mg} / \mathrm{kg})$ in male Sprague-Dawley rats once a day, along with a hypercholesterolemia diet for one month, inhibited collagen and ADP-induced platelet aggregation and ATP release. Besides, fermented garlic treatment downregulated the expression of sterol regulatory elementbinding protein, acetyltransferase-2, and 3-hydroxy-3-methylglutaryl coenzyme A [130]. Very similar results were also reported by Irfan et al. [131]. Several clinical trials have been conducted in the recent years to investigate the cardioprotective effects of BG. Most of the studies have been found to have positive effects. In a study, Seo et al. [132] showed that a 12 week aged garlic extract regimen with regular exercise reduced cardiovascular risk factors in postmenopausal by decreasing the body weight, body mass index, total cholesterol, LDL-C, malondialdehyde, and homocysteine levels. In another study, Jung et al. [133] investigated whether aged black garlic supplementation could improve blood lipid profile in mild hypercholesterolemia patients. They found that aged black garlic supplement increased the high-density lipoprotein cholesterol levels with the ratio of low-density lipoprotein cholesterol/apolipoprotein B with a decrease in the levels of apolipoprotein B. While two different clinical trials showed that aged garlic extract exerted selective inhibition on platelet aggregation, adhesion, and platelet functions. Aged garlic also significantly suppressed the total percentage and initial platelet aggregation rate [134,135]. Another study, where patients with metabolic syndrome received $1.2 \mathrm{~g} /$ day of aged garlic extract for 12 weeks, showed that plasma adiponectin levels were increased after the administration of aged garlic extract [136]. On the other hand, a very recent clinical trial study conducted by Wlosinska et al. [137], who reported that daily supplementation of aged garlic extract $(2400 \mathrm{mg})$ for one year lowered the IL-6 in female patients with a low-risk profile of cardiovascular diseases.

\subsubsection{Black Garlic and Arterial Hypertension}

A systolic blood pressure (SBP) of $140 \mathrm{~mm} \mathrm{Hg}$ or over and a diastolic blood pressure (DBP) of $90 \mathrm{~mm} \mathrm{Hg}$ or higher, or both, is considered arterial hypertension. Several risk factors are associated with the development of arterial hypertension. Recent studies have demonstrated that arterial stiffness precedes hypertension as well as causing a gradual increase in SBP [138]. In most cases, suffering from a debilitating disease such as arterial 
hypertension results in premature death. On the other hand, the renin-angiotensin system (RAS) is an associated hormone group that works together to regulate blood pressure, cardiovascular, and kidney function. It is well documented that RAS dysregulation might be linked to arterial hypertension, cardiovascular, and kidney disease [139]. According to the classical concept of the RAS pathway for arterial hypertension, renin cleaves its substrate, angiotensinogen, to create the inactive peptide angiotensin I, which is then converted to angiotensin II by endothelial angiotensin-converting enzyme (ACE). The most extensive activation of angiotensin II by ACE occurs in the lungs. Angiotensin II acts as a vasoconstrictor and stimulates the production of aldosterone from the adrenal gland, resulting in sodium retention and increased blood pressure [139]. Numerous studies showed the potential effects of BG on decreasing arterial hypertension and inhibiting ACE (Table 6).

Ried et al. [140] carried out a clinical trial on 88 patients with uncontrolled arterial hypertension patients. After 12 weeks of study, the findings indicated that aged garlic extract significantly reduced mean blood pressure along with arterial stiffness, mean arterial pressure, central blood pressure, central pulse pressure, pulse wave velocity, and augmentation pressure. Aged garlic extract administration for 12 weeks in 49 participants with uncontrolled arterial hypertension was also found effective in reducing blood pressure and had the potential to improve inflammation, arterial stiffness, and enhanced gut microbial profile [141]. In another clinical trial, a systolic blood pressure reduction was observed in 50 patients with uncontrolled pressure, the average decline being $10.2 \pm 4.3 \mathrm{~mm} \mathrm{Hg}$ [142]

Similarly, animal studies have shown the potential effects of BG extracts and their bioactive compounds on the inhibition of endothelial ACE activity (Table 6). In 2010, Castro et al. [143] conducted a study on spontaneously hypertensive rats to observe the effects of allyl methyl sulfide (AMS) and DAS on the growth and migration of cultured aortic smooth muscle cells. The authors found that both AMS and DAS inhibited aortic smooth muscle cell angiotensin II-stimulated cell-cycle progression and migration. In addition, the inhibitory actions of these compounds are possibly connected with the suppression of extracellular signal-regulated kinase $1 / 2$ phosphorylation and prevention of the cell cycle inhibitor p27 downregulation. In a separate study, Yu et al. [144] reported that BG extract was the most active in $\mathrm{ACE}$ inhibition with the lowest $\mathrm{IC}_{50}$ value $(0.04 \mathrm{mg} / \mathrm{mL})$ compared to raw garlic extract. Having said that, the authors also identified two Amadori compounds in BG extract, specifically N-(1-deoxy-D-fructos-1-yl)-1-arginine and N-(1-deoxy-D-fructos-1-yl)-1methionine, which were probably attributed to ACE inhibitory activity. It has also been reported by Jang et al. [145], in their study, that ACE inhibitory effects of the BG extract were greater $(88.8 \%)$ than normal garlic extract $(52.7 \%)$. Additionally, a recent study indicated that high levels of oxygen free radicals (OFRs) in the hypothalamic paraventricular nucleus $(\mathrm{PVN})$ contribute to the potentiation of the vasoconstrictor angiotensin II and the cardiac sympathetic afferent reflex (CSAR), which may result in hypertension [146]. Based on their hypothesis, Miao et al. [147] explored the antihypertensive effect of BG in spontaneously hypertensive rats (SHRs) and demonstrated that BG exerted a potential antihypertensive effect through OFRs in the plasma and PVN of SHRs. The authors concluded that bioactive compounds of BG may be transported across the blood-brain barrier of SHRs into PVN to scavenge excess OFRs, hence lowering blood pressure by inhibiting angiotensin II and CSAR potentiation.

However, there is still not enough data to suggest BG for the treatment of hypertensive patients as a standard clinical therapy. More properly designed and analyzed trials are needed for a definite conclusion.

\subsubsection{Black Garlic and Atherosclerosis}

Atherosclerosis occurs as a result of fat, cholesterol, and other substances interacting within the cellular components of the arterial wall. These deposits are called plaques. Over time, these plaques can eventually narrow or totally block the arteries, causing complications throughout the body [148]. Numerous pre-clinical and clinical investigations 
have demonstrated and confirmed BG's efficacy in preventing and treating atherosclerosis (Table 6). Early studies on experimental ApoE-KO mice showed that aged garlic extract suppressed the development of atherosclerosis in ApoE-KO mice by $22 \%$ in a 12 -week study. Treatment with aged garlic extract significantly suppressed the increase in serum concentrations of total cholesterol, triglycerides (TGs), and reduced the relative abundance of $\mathrm{CD}_{11 \mathrm{~b}^{+}}$cells in ApoE-KO mice [149]. In another study, aged garlic extract exerts anti-atherogenic effects in cholesterol-fed rabbits through reduction of fatty steak development, vessel wall cholesterol accumulation, and the development of fibro-fatty plaques as well as lowering the progression of coronary artery calcification (CAC) [150]. In a randomized double-blind placebo-controlled trial, aged garlic extract significantly inhibited CAC progression, lowered the levels of IL-6 glucose, and blood pressure in 104 patients at increased risk of cardiovascular events after taking $2400 \mathrm{mg} /$ daily of aged garlic extract for one year [151]. Another randomized clinical trial showed that a combination of aged garlic extract and co-enzyme Q10 suppressed the CAC progression and significantly decreased carbon reactive protein levels [152]. In 2009, a placebo-controlled, double-blind, randomized study involved 65 intermediate-risk patients and supplied them a capsule containing aged garlic extract with vitamin B6, vitamin B12, folic acid, and L-arginine for 12 months. At the end of the clinical trial, the data suggested that aged garlic extract with supplements decreased TGs, LDL-C, homocysteine, immunoglobulin $\mathrm{G}$, immunoglobulin $\mathrm{M}$ autoantibodies to malondialdehyde-low density lipoprotein and apolipoprotein B-immune complexes while high-density lipoprotein, oxidized phospholipids/apolipoprotein B and lipoprotein were significantly increased [153]. Furthermore, a study of 60 asymptomatic patients showed that aged garlic extract with supplements decreased the levels of epicardial adipose tissue, pericardial adipose tissue, periaortic adipose tissue, and subcutaneous adipose tissue after 12 months of treatment. Thus, aged garlic extract with supplements reduced the metabolic risk and the severity of coronary artery calcification by suppressing the progression rate of adipose tissue volume [154].

Table 6. Effects of black garlic on cardiovascular system diseases.

\begin{tabular}{|c|c|c|c|c|c|}
\hline Diseases & Products & $\begin{array}{l}\text { Subjects/Cell } \\
\text { Line/Animal } \\
\text { Model }\end{array}$ & Outcomes & Mode of Action & Ref. \\
\hline \multirow{4}{*}{$\begin{array}{c}\text { Platelet } \\
\text { Aggregation }\end{array}$} & Aged garlic & $\begin{array}{l}30 \text { participants } \\
\text { Study period: } \\
12 \text { weeks }\end{array}$ & $\begin{array}{l}\text { Reduced cardiovascular } \\
\text { risk factors }\end{array}$ & $\begin{array}{c}\downarrow \text { BW, BMI, TC, LDL-C, MDA, } \\
\downarrow \text { Homocysteine } \\
\uparrow \quad \mathrm{TG}\end{array}$ & [132] \\
\hline & $\begin{array}{c}\text { Aged } \\
\text { black garlic }\end{array}$ & $\begin{array}{l}28 \text { participants } \\
\text { Study period: } \\
12 \text { weeks }\end{array}$ & $\begin{array}{c}\text { Reduced atherogenic } \\
\text { markers. }\end{array}$ & $\uparrow_{\text {Ratio of LDL-C/apo-B }}^{\text {HDL-C }}$ & [133] \\
\hline & $\begin{array}{l}\text { Aged garlic } \\
\text { (AG) }\end{array}$ & $\begin{array}{l}34 \text { participants } \\
\text { Study period: } \\
44 \text { weeks }\end{array}$ & $\begin{array}{l}\text { AG exerted selective } \\
\text { inhibition on platelet } \\
\text { aggregation and } \\
\text { adhesion, platelet } \\
\text { functions. }\end{array}$ & & [134] \\
\hline & $\begin{array}{l}\text { Aged garlic } \\
\text { (AG) }\end{array}$ & $\begin{array}{l}23 \text { participants } \\
\text { Study period: } \\
13 \text { weeks }\end{array}$ & $\begin{array}{c}\text { AG substantially } \\
\text { suppressed the total } \\
\text { percentage and initial } \\
\text { platelet aggregation rate. }\end{array}$ & & [135] \\
\hline
\end{tabular}


Table 6. Cont

\begin{tabular}{|c|c|c|c|c|c|}
\hline Diseases & Products & $\begin{array}{l}\text { Subjects/Cell } \\
\text { Line/Animal } \\
\text { Model }\end{array}$ & Outcomes & Mode of Action & Ref. \\
\hline & $\begin{array}{l}\text { Aged garlic } \\
\text { (AG) }\end{array}$ & $\begin{array}{l}43 \text { participants } \\
\text { Study period: } \\
24 \text { weeks }\end{array}$ & $\begin{array}{l}\text { AG increased plasma } \\
\text { adiponectin levels. }\end{array}$ & & [136] \\
\hline & $\begin{array}{l}\text { Aged garlic } \\
\text { (AG) }\end{array}$ & $\begin{array}{l}31 \text { participants } \\
\text { Study period: } \\
12 \text { months }\end{array}$ & $\begin{array}{l}\text { AG lowered IL-6 in } \\
\text { females with a low-risk } \\
\text { profile of the } \\
\text { cardiovascular disease. }\end{array}$ & & [137] \\
\hline & $\begin{array}{l}\text { Aged garlic } \\
\text { (AG) }\end{array}$ & Male Wistar rats & $\begin{array}{l}\text { Suppressed the platelet } \\
\text { aggregation by changing } \\
\text { the functional property } \\
\text { of the platelets. }\end{array}$ & $\begin{array}{c}\text { } \\
\text { Extracellular ATP } \\
\text { Extra- and intracellular TXB } \\
\text { Suppressed the phosphorylation of } \\
\text { collagen-induced ERK, p38, and } \\
\text { JNK. }\end{array}$ & [129] \\
\hline & $\begin{array}{l}\text { Fermented } \\
\text { garlic }\end{array}$ & $\begin{array}{c}\text { Male } \\
\text { Sprague-Dawley } \\
\text { rats }\end{array}$ & $\begin{array}{c}\text { Ameliorated } \\
\text { hypercholesterolemia } \\
\text { and inhibited platelet } \\
\text { activation. }\end{array}$ & $\downarrow \begin{array}{c}\text { TG, SERBP-2, } \\
\text { ACAT-2, HMG-CoA }\end{array}$ & [131] \\
\hline & $\begin{array}{l}\text { Fermented } \\
\text { garlic (FG) }\end{array}$ & $\begin{array}{l}\text { Male } \\
\text { Sprague-Dawley } \\
\text { rats }\end{array}$ & $\begin{array}{c}\text { FG significantly } \\
\text { inhibited platelet } \\
\text { aggregation and granule } \\
\text { secretion in } \\
\text { hypercholesterolemic } \\
\text { rats. }\end{array}$ & $\begin{array}{c}\text { Inhibited collagen and } \\
\text { ADP-induced platelet aggregation } \\
\text { and ATP release. Downregulated } \\
\text { the expression of SERBP, ACAT-2, } \\
\text { and HMG-CoA. }\end{array}$ & [130] \\
\hline \multirow{4}{*}{$\begin{array}{l}\text { Arterial Hy- } \\
\text { pertension }\end{array}$} & $\begin{array}{l}\text { Aged garlic } \\
\text { (AG) }\end{array}$ & $\begin{array}{l}88 \text { patients with } \\
\text { uncontrolled } \\
\text { arterial } \\
\text { hypertension. } \\
\text { Study period: } \\
12 \text { weeks }\end{array}$ & $\begin{array}{l}\text { Reduced mean blood } \\
\text { pressure along with } \\
\text { arterial stiffness, mean } \\
\text { arterial pressure, central } \\
\text { blood pressure, central } \\
\text { pulse pressure, } \\
\text { pulse-wave velocity, and } \\
\text { augmentation pressure. }\end{array}$ & & [140] \\
\hline & $\begin{array}{l}\text { Aged garlic } \\
\text { (AG) }\end{array}$ & $\begin{array}{l}49 \text { participants } \\
\text { with uncontrolled } \\
\text { arterial } \\
\text { hypertension. } \\
\text { Study period: } \\
12 \text { weeks }\end{array}$ & $\begin{array}{l}\text { AG was effective in } \\
\text { reducing blood pressure } \\
\text { and had the potential to } \\
\text { improve inflammation, } \\
\text { arterial stiffness, and gut } \\
\text { microbial profile. }\end{array}$ & & [141] \\
\hline & Aged garlic & $\begin{array}{l}9 \text { patients } \\
\text { Study period: } \\
12 \text { weeks }\end{array}$ & $\begin{array}{l}\text { Mean systolic blood } \\
\text { pressure was } \\
\text { significantly reduced. }\end{array}$ & & [155] \\
\hline & Aged garlic & $\begin{array}{l}50 \text { patients } \\
\text { Study period: } \\
12 \text { weeks }\end{array}$ & $\begin{array}{l}\text { Systolic blood pressure } \\
\text { was } \\
\text { reduced on an average of } \\
10.2 \pm 4.3 \mathrm{~mm} \mathrm{Hg} \text {. }\end{array}$ & & [142] \\
\hline $\begin{array}{l}\text { Hypertension } \\
\text { related to } \\
\text { RAS }\end{array}$ & $\begin{array}{l}\text { Allyl methyl } \\
\text { Sulfide (AMS) } \\
\text { and } \\
\text { diallyl sulfide } \\
\text { (DAS) }\end{array}$ & $\begin{array}{c}\text { Male } \\
\text { spontaneously } \\
\text { hypertensive rats } \\
\text { (SHRs) }\end{array}$ & $\begin{array}{l}\text { AMS and DAS inhibited } \\
\text { aortic smooth muscle cell } \\
\text { angiotensin II-stimulated } \\
\text { cell-cycle progression } \\
\text { and migration. }\end{array}$ & $\begin{array}{l}\text { The outcome was probably } \\
\text { mediated via upregulation of the } \\
\text { growth suppressor p27 and the } \\
\text { attenuation of ERK } 1 / 2 \\
\text { phosphorilation. }\end{array}$ & [143] \\
\hline
\end{tabular}


Table 6. Cont.

\begin{tabular}{|c|c|c|c|c|c|}
\hline Diseases & Products & $\begin{array}{l}\text { Subjects/Cell } \\
\text { Line/Animal } \\
\text { Model }\end{array}$ & Outcomes & Mode of Action & Ref. \\
\hline & $\begin{array}{l}\text { Black garlic } \\
\qquad(\mathrm{BG})\end{array}$ & $\begin{array}{c}\text { Male } \\
\text { spontaneously } \\
\text { hypertensive rats } \\
\text { (SHRs) }\end{array}$ & $\begin{array}{l}\text { BG exerted a potential } \\
\text { antihypertensive effect } \\
\text { through OFRs in the } \\
\text { plasma and PVN of } \\
\text { SHRs. }\end{array}$ & $\begin{array}{l}\text { Declined high blood pressure via } \\
\text { abolishing the potentiation of } \\
\text { angiotensin II and CSAR. }\end{array}$ & [147] \\
\hline & $\begin{array}{l}\text { Black garlic } \\
\qquad(\mathrm{BG})\end{array}$ & Rabbit lung ACE & $\begin{array}{l}\text { BG was the most active } \\
\text { in ACE inhibition with } \\
\text { the lowest } \mathrm{IC}_{50} \text { value } \\
(0.04 \mathrm{mg} / \mathrm{mL})\end{array}$ & $\begin{array}{c}\text { Amadori compounds (Fru-Arg and } \\
\text { Fru-Met) were probably attributed } \\
\text { to ACE } \\
\text { inhibitory activity. }\end{array}$ & [144] \\
\hline & Black garlic & & $\begin{array}{l}\text { ACE inhibitory effects } \\
\text { of the black garlic } \\
\text { extract were greater } \\
(88.8 \%) \text { than normal } \\
\text { garlic extract }(52.7 \%)\end{array}$ & & [145] \\
\hline \multirow{6}{*}{ Atherosclerosis } & $\begin{array}{l}\text { Aged } \\
\text { garlic } \\
(\mathrm{AG})\end{array}$ & $\begin{array}{l}104 \text { patients Study } \\
\text { period: } \\
12 \text { months }\end{array}$ & $\begin{array}{l}\text { AG suppressed the } \\
\text { atherosclerosis } \\
\text { progression. }\end{array}$ & $\begin{array}{l}\text { Inhibited CAC progression, } \\
\text { lowered the levels of IL-6, glucose, } \\
\text { and blood pressure. }\end{array}$ & [151] \\
\hline & $\begin{array}{c}\text { Aged } \\
\text { garlic } \\
(\mathrm{AG}) \\
\text { and } \\
\text { coenzyme } \\
\text { Q10 (CoQ10) }\end{array}$ & $\begin{array}{l}65 \text { patients } \\
\text { Study period: } \\
12 \text { months }\end{array}$ & $\begin{array}{l}\mathrm{AG}+\mathrm{CoQ} 10 \text { reduced } \\
\text { the } \\
\text { progression of coronary } \\
\text { atherosclerosis. }\end{array}$ & $\begin{array}{c}\text { Lowered CAC progression and } \\
\text { CRP levels. }\end{array}$ & [152] \\
\hline & $\begin{array}{l}\text { Aged } \\
\text { garlic }\end{array}$ & $\begin{array}{l}60 \text { patients } \\
\text { Study period: } \\
12 \text { months }\end{array}$ & $\begin{array}{l}\text { Reduced the } \\
\text { progression rate of } \\
\text { adipose tissue } \\
\text { volumes related to } \\
\text { CAC. }\end{array}$ & $\begin{array}{l}\text { Decreased the levels of EAT, PAT, } \\
\text { PaAT, and SAT. }\end{array}$ & [154] \\
\hline & $\begin{array}{l}\text { Aged } \\
\text { garlic supple- } \\
\text { mented with } \\
\text { B vitamins, } \\
\text { folic acid, and } \\
\text { L-arginine }\end{array}$ & $\begin{array}{l}65 \text { patients } \\
\text { Study period: } \\
12 \text { months }\end{array}$ & $\begin{array}{l}\text { Improved oxidative } \\
\text { biomarkers, vascular } \\
\text { function, and reduced } \\
\text { progression of } \\
\text { atherosclerosis. }\end{array}$ & $\begin{array}{c}\text { Lowered CAC progression. } \\
\text { Decreased TG, LDL-C, } \\
\text { homocysteine, IgG and IgM } \\
\text { autoantibodies to MDA-LDL and } \\
\text { apoB-immune complexes. } \\
\text { Increased HDL, OxPL/apoB, and } \\
\text { LP. }\end{array}$ & [153] \\
\hline & $\begin{array}{l}\text { Aged garlic } \\
\qquad(\mathrm{AG})\end{array}$ & ApoE-KO mice & $\begin{array}{l}\text { AG suppressed the } \\
\text { development of } \\
\text { atherosclerosis. }\end{array}$ & $\begin{array}{l}\text { Suppressed the increase in serum } \\
\text { concentrations of TC, TG and } \\
\text { reduced the relative abundance of } \\
\text { CD11b } \mathrm{b}^{+} \text {cells. }\end{array}$ & [149] \\
\hline & $\begin{array}{l}\text { Aged garlic } \\
\quad(A G)\end{array}$ & $\begin{array}{l}\text { New Zealand white } \\
\text { rabbit }\end{array}$ & $\begin{array}{l}\text { AG protected the onset } \\
\text { of atherosclerosis. }\end{array}$ & $\begin{array}{l}\text { Reduced fatty streak development, } \\
\text { vessel wall cholesterol } \\
\text { accumulation, and the } \\
\text { development of fibro-fatty plaques. }\end{array}$ & [150] \\
\hline
\end{tabular}

BW: body weight; BMI: body mass index; TC: total cholesterol; LDL-C: low-density lipoprotein cholesterol; MDA: malondialdehyde; TG: triglyceride; HDL-C: high-density lipoprotein cholesterol; LDL-C/apo-B: low-density lipoprotein cholesterol/apolipoprotein B; ATP: adenosine triphosphate; $\mathrm{TXB}_{2}$ : thromboxane B2; ERK: extracellular-signal-regulated kinase; JNK: c-Jun N-terminal kinase; SERBP-2: sterol regulatory element binding protein-2; ACAT-2: acetyltransferase-2; HMG-CoA: 3-hydroxy-3-methylglutaryl coenzyme A; ADP: adenosine diphosphate; IL-6:interleukin-6; RAS: renin-angiotensin system; OFRs: oxygen free radicals; PVN: paraventricular nucleus; CSAR: cardiac sympathetic afferent reflex; ACE: angiotensin-converting enzyme; Fru-Arg: N-(1-deoxy-D-fructos-1-yl)-1-arginine; Fru-Met: N-(1-deoxy-Dfructos-1-yl)-1-methionine; CAC: coronary artery calcification; CRP: c-reactive protein; EAT: epicardial adipose tissue; PAT: pericardial adipose tissue; PaAT: periaortic adipose tissue; SAT: subcutaneous adipose tissue; IgG: immunoglobulin G; IgM: immunoglobulin M; MDALDL: malondialdehyde-low-density lipoprotein; HDL: high-density lipoprotein; OxPL/apoB: oxidized phospholipids/apolipoprotein B; LP: lipoprotein. 


\subsection{Effects of Black Garlic on Neurodegenerative Diseases}

There has been an alarming increase in the incidence of neurodegenerative disorders. Although treatments for Alzheimer's, Parkinson's, and Huntington's diseases have shown significant advancement, the pathophysiology of these diseases is not fully clear yet. It is expected that an early decrease in hallmarks of degenerative processes (e.g., apoptosis, inflammation, oxidative stress, and immune dysfunction) could delay the onset and reduce the symptoms of neurodegenerative diseases by providing human subjects with neuroprotective agents. A number of studies have been documented aged black garlic and SAC as potential agents to protect the brain against neurodegeneration (Table 7). In one preliminary study, pretreatment of the Alzheimer's Swedish double mutant mouse model (Tg2576) with aged garlic extract (2\%) reduced cerebral plaques, detergent soluble, and detergent-resistant $\mathrm{A} \beta$-species with concomitantly increased soluble amyloid precursor protein $\alpha$, reduced inflammation, and conformational change in tau. Thus, the authors suggested that changes in tau phosphorylation appear to be mediated by glycogen synthase kinase 3 beta [156]. In another study, Jeong and his colleagues found that aged garlic extract ameliorated against A $\beta$-induced neurotoxicity in PC12 mice by showing 2,2'-azino-bis (3-ethylbenzthiazoline6-sulfonic acid) diammonium salt radical scavenging activity, malondialdehyde inhibitory effect, and reducing intracellular ROS accumulation. In addition, aged garlic extract also improved cognitive impairment in ICR mice by attenuating $A \beta$-induced learning and memory deficits [157]. BG may also prevent cognitive decline by protecting neurons from $A \beta$-induced neurotoxicity, and apoptosis, thereby avoiding neuronal death caused by ischemia or reperfusion and improving memory retention and learning ability. In this context, Wichai et al. [158] conducted a dose-dependent study of aged garlic extract on $\mathrm{A} \beta$-induced neurotoxicity rats for 8 weeks. The authors found that aged garlic extract increased the activities of SOD, GPx, and reduced the malondialdehyde levels. Thus, these findings suggested that aged garlic extract improved cognitive dysfunction through its antioxidant effects. Interestingly, another study proposed a possible mechanism, where aged garlic extract attenuated the impairment of working memory via the modification of cholinergic neurons, vesicular glutamate transporter 1, and glutamate decarboxylase in the hippocampus of $A \beta$-induced rats [159]. Several studies have mentioned that oxidative stress is generated by an increase in the buildup of ROS, which has been linked to the promotion of aging and the pathogenesis of several neurodegenerative disorders. Under all such conditions, additional antioxidant protection is required. Ray et al. [160] showed that aged garlic extract and SAC were able to prevent oxidative insults to neuron cells ( $80 \%$ ) from ROS-mediated damage, and preserved the levels of presynaptic protein $(\sim 70 \%)$, such as SNAP25, in the neuronal culture (PC12) and amyloid precursor protein-transgenic (APP-Tg) mouse model. Furthermore, in a lipopolysaccharide-activated murine BV-2 microglial cell study, aged garlic extract and its compound $N$ - $\alpha$-(1-deoxy-D-fructos-1-yl)-Larginine attenuated neuroinflammatory responses by suppressing the NO production and regulating the expression of multiple protein targets associated with oxidative stress [161].

On the other hand, Parkinson's disease (PD) is the second most prevalent age-related neurodegenerative disease with an unclear etiology. Oxidative stress and inflammation play a critical role in the onset and progression of Parkinson's disease. BG and its compounds have been shown to protect cells from apoptosis, mitochondrial dysfunction, inflammation, and oxidative stress. Very limited studies have shown the effects of BG on Parkinson's disease. One study evaluated the effects of SAC against oxidative stress in 1-methyl-4phenylpyridinium ion $\left(\mathrm{MPP}^{+}\right)$-induced parkinsonism in C57BL/6J mice. SAC $(125 \mathrm{mg} / \mathrm{kg}$ i.p.) administrated to the mice for 17 days significantly ameliorated $\mathrm{MPP}^{+}$-induced lipid peroxidation, ROS production, loss of dopamine in the striatum, and improved locomotion deficits [162]. However, there is a need for more animal studies and clinical trials to confirm the therapeutic effects of BG on Parkinson's diseases. 
Table 7. Effects of black garlic on neurodegeneration diseases.

\begin{tabular}{|c|c|c|c|c|c|}
\hline Diseases & Products & $\begin{array}{l}\text { Subjects/Cell } \\
\text { Line/Animal } \\
\text { Model }\end{array}$ & Outcomes & Mode of Action & Ref. \\
\hline \multirow{6}{*}{ Alzheimer's } & Aged garlic (AG) & $\begin{array}{c}\text { Transgenic model } \\
\text { Tg2576 }\end{array}$ & $\begin{array}{c}\text { AG reduced cerebral } \\
\text { plaques, detergent soluble } \\
\text { and detergent resistant } \\
\text { (fibrillar) A } \beta \text {-species with } \\
\text { concomitantly increased } \\
\alpha \text {-cleaved sAPP } \alpha \text {, reduced } \\
\text { inflammation and } \\
\text { conformational change in } \\
\text { tau. }\end{array}$ & $\begin{array}{c}\text { The observed change in } \\
\text { tau phosphorylation } \\
\text { appears to involve } \\
\text { GSK-3 } \beta \text {. }\end{array}$ & [156] \\
\hline & $\begin{array}{c}\text { Aged } \\
\text { garlic (AG) }\end{array}$ & $\begin{array}{l}\text { PC12 cell } \\
\text { ICR mice }\end{array}$ & $\begin{array}{l}\text { AG ameliorated against } \\
\mathrm{A} \beta \text {-induced neurotoxicity } \\
\text { and cognitive impairment. }\end{array}$ & $\begin{array}{l}\text { AG showed ABTS } \\
\text { radical scavenging } \\
\text { activity, MDA inhibitory } \\
\text { effect and reduced } \\
\text { intracellular ROS } \\
\text { accumulation. }\end{array}$ & [157] \\
\hline & Aged garlic (AG) & Male Wistar rat & $\begin{array}{c}\text { AG ameliorated the } \\
\text { cognitive dysfunction in } \\
\text { A } \beta \text {-induced neurotoxicity } \\
\text { rats. }\end{array}$ & $\begin{array}{cc}\uparrow & \text { SOD, GPx } \\
\downarrow & \text { MDA levels }\end{array}$ & [158] \\
\hline & $\begin{array}{l}\text { Aged garlic (AG) } \\
\text { and Fru-Arg }\end{array}$ & $\begin{array}{l}\text { Murine BV-2 } \\
\text { microglial cell }\end{array}$ & $\begin{array}{c}\text { AG and Fru-Arg attenuated } \\
\text { neuroinflammatory } \\
\text { responses. }\end{array}$ & $\begin{array}{l}\text { Suppressed the } \\
\text { production of NO. } \\
\text { Regulated the } \\
\text { expression of multiple } \\
\text { protein targets } \\
\text { associated with } \\
\text { oxidative stress. }\end{array}$ & [161] \\
\hline & $\begin{array}{l}\text { Aged garlic } \\
\text { (AG) }\end{array}$ & Male Wistar rats & $\begin{array}{l}\text { AG significantly improved } \\
\text { the working memory and } \\
\text { tended to improve the } \\
\text { reference memory in } \\
\text { cognitively impaired rats. }\end{array}$ & $\begin{array}{l}\text { Modified the cholinergic } \\
\text { neurons, VGLUT1, and } \\
\text { GAD in the } \\
\text { hippocampus of } \\
\text { A } \beta \text {-induced rats. }\end{array}$ & [159] \\
\hline & $\begin{array}{l}\text { Aged garlic } \\
\text { (AG) } \\
\text { and S-allyl-L- } \\
\text { cysteine (SAC) }\end{array}$ & $\begin{array}{l}\text { PC12 cells, } \\
\text { Tg2576 } \\
\text { transgenic mice }\end{array}$ & $\begin{array}{l}\text { Both AG and SAC treatment } \\
\text { protected neuronal cells } \\
\text { from ROS-mediated } \\
\text { oxidative insults and } \\
\text { preserved the levels of } \\
\text { pre-synaptic protein such as } \\
\text { SNAP25. }\end{array}$ & & [160] \\
\hline Parkinson's & $\begin{array}{l}\text { S-allyl-L- } \\
\text { cysteine } \\
\text { (SAC) }\end{array}$ & C57BL/6J mice & $\begin{array}{l}\text { SAC protected against } \\
\text { oxidative stress in } \\
\text { 1-methyl-4 } \\
\text { phenylpyridinium-induced } \\
\text { parkinsonism in mice. }\end{array}$ & $\begin{array}{c}\text { Ameliorated } \\
\mathrm{MPP}^{+} \text {-induced lipid } \\
\text { peroxidation, ROS } \\
\text { production, loss of } \\
\text { dopamine in striatum, } \\
\text { and improved } \\
\text { locomotion deficits. }\end{array}$ & [162] \\
\hline $\begin{array}{l}\text { Cerebral } \\
\text { ischemia }\end{array}$ & $\begin{array}{l}\text { S-allyl-L- } \\
\text { cysteine } \\
\text { (SAC) }\end{array}$ & Male Wistar rats & $\begin{array}{c}\text { SAC mitigated oxidative } \\
\text { damage and improved } \\
\text { neurologic deficit. }\end{array}$ & $\begin{array}{l}\text { Reduced ischemic lesion } \\
\text { volume, suppressed } \\
\text { neuronal loss, and } \\
\text { inhibited glial fibrillary } \\
\text { acidic protein and } \\
\text { inducible nitric oxide } \\
\text { expression. }\end{array}$ & [163] \\
\hline
\end{tabular}


Table 7. Cont

\begin{tabular}{|c|c|c|c|c|c|}
\hline Diseases & Products & $\begin{array}{l}\text { Subjects/Cell } \\
\text { Line/Animal } \\
\text { Model }\end{array}$ & Outcomes & Mode of Action & Ref. \\
\hline & $\begin{array}{l}\text { Aged garlic } \\
\text { (AG) } \\
\text { and S-allyl-L- } \\
\text { cysteine (SAC) }\end{array}$ & Male Wistar rats & $\begin{array}{l}\text { Both AG and SAC treatment } \\
\text { induced neuroprotection. }\end{array}$ & $\begin{array}{l}\text { Increased GLUT3 and } \\
\text { GCLC mRNA } \\
\text { expression levels. }\end{array}$ & [167] \\
\hline & $\begin{array}{l}\text { S-allyl-L- } \\
\text { cysteine } \\
\text { (SAC) }\end{array}$ & Male Wistar rats & $\begin{array}{l}\text { SAC diminished cerebral } \\
\text { ischemia-induced } \\
\text { mitochondrial dysfunctions } \\
\text { in hippocampus. }\end{array}$ & $\begin{array}{l}\text { Restored GSH and } \\
\text { G6-PD. Decreased LPO, } \\
\text { PC, and } \mathrm{H}_{2} \mathrm{O}_{2} \text { content as } \\
\text { well as the brain edema. }\end{array}$ & [165] \\
\hline & Aged garlic (AG) & Male Wistar rats & $\begin{array}{l}\text { AG attenuated the cerebral } \\
\text { ischemia-induced } \\
\text { inflammation. }\end{array}$ & $\begin{array}{l}\text { Attenuated the increase } \\
\text { in the levels of } 8-O H d G, \\
\text { TNF- } \alpha \text {, and COX-2 } \\
\text { protein. }\end{array}$ & [166] \\
\hline & $\begin{array}{l}\text { Aged garlic } \\
\text { (AG) }\end{array}$ & Male Wistar rats & $\begin{array}{c}\text { AG protected against } \\
\text { ischemia-induced brain } \\
\text { damage. }\end{array}$ & $\begin{array}{l}\text { Decreased mRNA } \\
\text { expression of NMDA } \\
\text { receptor subunits after } \\
\text { ischemia. Prevented } \\
\text { ischemia-induced } \\
\text { reduction in } \\
\text { mitochondrial potential } \\
\text { and in ATP synthesis. }\end{array}$ & [164] \\
\hline
\end{tabular}

A $\beta$ : $\beta$-amyloid; sAPP $\alpha$ : soluble amyloid precursor protein $\alpha$; GSK-3 $\beta$ : glycogen synthase kinase 3 beta; ABTS: 2,2 -azino-bis (3ethylbenzothiazoline-6-sulfonic acid; MDA: malondialdehyde; ROS: reactive oxygen species; SOD: superoxide dismutase; GPx: glutathione peroxidase; Fru-Arg: N- $\alpha$-(1-deoxy-D-fructos-1-yl)-L-arginine; NO: nitric oxide; VGLUT1:vesicular glutamate transporter 1; GAD: glutamate decarboxylase; SNAP25: synaptosomal associated protein of $25 \mathrm{kDa}$; $\mathrm{MPP}^{+}$: 1-methyl-4-phenylpyridinium ion; GLUT3: glucose transporter 3; GCLC: glutamate cysteine ligase catalytic subunit; GSH: glutathione; G6-PD: glucose 6-phosphate dehydrogenase; LPO: lipid peroxidation; PC: protein carbonyl; 8-OHdG: 8-hydroxy-2-deoxyguanosine; TNF- $\alpha$ : tumor necrosis factor- $\alpha$; COX-2: cyclooxygenase-2; mRNA: messenger ribonucleic acid; NMDA: N-methyl-D-aspartate; ATP: adenosine triphosphate.

Cerebral ischemia, including stroke, is the world's leading cause of death and disability. It causes neural function loss and irreparable damage to the brain. Cerebral ischemia is defined by a shortage of oxygen, a halt of blood flow, and an influx of calcium, resulting in an increase in ROS, mitochondrial malfunction, and neuronal death. A study conducted by Ashafaq et al. [163] demonstrated the ability of SAC to mitigate oxidative damage and improve neurological deficit in a rat model of focal cerebral ischemia. SAC treatment significantly reduced ischemic lesion volume, suppressed neuronal loss, inhibited glial fibrillary acidic protein, and inducible nitric oxide expression. In another study, both aged garlic extract and SAC showed the ability to induce neuroprotection by controlling ROS. This effect was related to their antioxidant ability in increasing the mRNA expression levels of glucose transporter 3 and glutamate-cysteine ligase catalytic subunit in rats with transient focal cerebral ischemia. Similarly, Cervantes et al. [164] reported that treatment of a rat model of stroke with aged garlic extracts protected against ischemiainduced brain damage. The effects of aged garlic extract attributed to the decrease in the mRNA expression of N-methyl-D-aspartate receptor subunits after ischemia prevents ischemia-induced reduction in mitochondrial potential and ATP synthesis. SAC, at a dose of $300 \mathrm{mg} / \mathrm{kg}$, treated cerebral ischemia in male Wister rats. The results suggested that SAC diminished cerebral ischemia-induced mitochondrial dysfunctions in the hippocampus by restoring the GSH, glucose 6-phosphate dehydrogenase, and decreasing lipid peroxidation, protein carbonyl, hydrogen peroxide $\left(\mathrm{H}_{2} \mathrm{O}_{2}\right)$ content as well as brain edema [165]. The neuroprotective effect of aged garlic extract is not only due to its anti-oxidant effect but also to its anti-inflammatory effect. In a study, Colin-Gonzalez et al. [166] showed that aged garlic extract administration attenuated the increase in the levels of oxidative stress markers such as 8-hydroxy-2-deoxyguanosine and TNF- $\alpha$ with COX-2 protein. 


\subsection{Effects of Black Garlic on Cancer Diseases}

Cancer is one of the leading causes of death throughout the world. The treatment of cancer varies and usually includes surgery, radiation therapy, and chemotherapy. The utilization of natural products in cancer therapy is a rapidly growing field of study. Many pre-clinical studies have been conducted to investigate the anti-cancer effects of BG due to its various health benefits and pharmacological effects including anti-oxidant, antiinflammatory, apoptosis induction, anti-proliferation, and anti-angiogenesis (Table 8). In vitro studies have shown that BG is very capable of suppressing cancer cell growth and proliferation in multiple cancer cell lines. For example, one in vitro study demonstrated the ability of aged black garlic extract to suppress colon cancer cell growth (HT29) and promoted apoptosis by inhibiting the P13KAkt pathway [32]. Moreover, aged black garlic extract was found to be able to inhibit gastric cell growth both in vitro and in vivo animal studies. An in vitro study revealed dose-dependent apoptosis in SGC-7901 cells treated with aged black garlic extract while an in vivo animal study showed the anti-cancer effects of aged black garlic extract such as tumor growth suppression in tumor-bearing mice. The authors suggested that the anti-cancer effects of aged black garlic extracts may be attributed to their antioxidant and immunomodulatory properties [33]. Similar inhibition properties of BG extract and its compound, SAMC, were reported in the case of lung cancer Lewis cells and thyroid cancer cell line (HPACC-8305C), respectively $[168,169]$. Numerous studies have demonstrated BG's anti-tumor properties through suppression of cell proliferation against colon cancer and gastric cancer. In 2014, Jikihara and his collaborators treated F344 rats and DLD-1 human colon cancer cells with aged garlic extract. The results showed inhibition of proliferative activity in adenoma and adenocarcinoma lesions. In addition, aged garlic extract delayed cell cycle progression by downregulating cyclin B1 and cyclindependent kinase 1 expression via inactivation of NF- $\kappa \beta$ but did not induce apoptosis [170]. Through the inhibition of matrix metalloproteinase-2, matrix metalloproteinase-9, and repressed levels of claudin proteins, water extract of aged black garlic may also inhibit tumor metastasis and invasion in gastric cell (AGS) [171]. Aged garlic extract has also been reported to have a chemo-sensitizing effect on doxorubicin (DOX) in the human breast cancer cell (MCF-7). Aged garlic extract improves the cytotoxic effect of DOX on MCF-7 cells, most likely through apoptosis induction, enhanced intracellular DOX accumulation, and suppression of P-glycoprotein activity [172]. Recently, the anticancer effects of SAMC, one of the BG compounds, have been demonstrated on prostate cancer, liver cancer, bladder cancer, and ovarian cancer. It was demonstrated that SAMC could: (i) show positive effects against prostate cancer cells by altering prostate biomarker expression and utilizing testosterone to restore E-cadherin's expression [173-178]; (ii) promote MAPK inhibitor-induced apoptosis by activating the TGF- $\beta$ signaling pathway [179]; (iii) inhibit the survival, invasion, and migration of bladder cancer cells through the inactivation of inhibitor of differentiation-1 pathway [180]; and (iv) suppress both the proliferation and distant metastasis of epithelial ovarian cancer cells [181]. 
Table 8. Effects of black garlic on different cancers.

\begin{tabular}{|c|c|c|c|c|c|}
\hline Diseases & Products & $\begin{array}{c}\text { Subjects/Cell } \\
\text { Line/Animal Model }\end{array}$ & Outcomes & Mode of Action & Ref. \\
\hline \multirow[t]{2}{*}{$\begin{array}{l}\text { Colon } \\
\text { cancer }\end{array}$} & $\begin{array}{l}\text { Aged black } \\
\text { garlic } \\
(\mathrm{ABG})\end{array}$ & HT29 cell & $\begin{array}{l}\text { ABG inhibited colon } \\
\text { cancer cell growth }\end{array}$ & $\begin{array}{l}\text { ABG reduced HT29 cell } \\
\text { growth and promoted } \\
\text { apoptosis by inhibiting the } \\
\text { PI3KAkt pathway. }\end{array}$ & [32] \\
\hline & $\begin{array}{l}\text { Aged garlic } \\
\text { (AG) }\end{array}$ & $\begin{array}{l}\text { DLD-1 cell and F344 } \\
\text { rats }\end{array}$ & $\begin{array}{c}\text { AG inhibited } \\
\text { 1,2-dimethylhydrazine- } \\
\text { induced colon tumor } \\
\text { development. }\end{array}$ & $\begin{array}{l}\text { AG delayed cell cycle } \\
\text { progression by } \\
\text { downregulating cyclin B1 and } \\
\text { cdk1 expression via } \\
\text { inactivation of NF-kB but did } \\
\text { not induce apoptosis. }\end{array}$ & [170] \\
\hline $\begin{array}{l}\text { Prostate } \\
\text { cancer }\end{array}$ & SAMC & $\begin{array}{l}\text { LNCaP cell, PC-3, DU } \\
145 \text { cells }\end{array}$ & $\begin{array}{l}\text { SAMC showed positive } \\
\text { effects against prostate } \\
\text { cancer cells. }\end{array}$ & $\begin{array}{l}\text { Rescued GSH deficits, altered } \\
\text { prostate biomarker expression } \\
\text { and utilized testosterone, } \\
\text { restored the expression of } \\
\text { E-cadherin. }\end{array}$ & [173-178] \\
\hline \multirow[t]{2}{*}{$\begin{array}{l}\text { Gastric } \\
\text { cancer }\end{array}$} & $\begin{array}{l}\text { Aged black } \\
\text { garlic } \\
\text { (ABG) }\end{array}$ & AGS cells & $\begin{array}{l}\text { ABG treatment inhibited } \\
\text { tumor metastasis and } \\
\text { invasion. }\end{array}$ & $\begin{array}{l}\text { ABG increased the tightness } \\
\text { of tight junction. Inhibited the } \\
\text { activities of MMP-2 and -9 in } \\
\text { AGS cells. Repressed the } \\
\text { levels of claudin proteins. }\end{array}$ & [171] \\
\hline & $\begin{array}{l}\text { Aged black } \\
\text { garlic } \\
(\mathrm{ABG})\end{array}$ & SGC-7901 cells & $\begin{array}{l}\text { ABG induced inhibition } \\
\text { of gastric cancer cell } \\
\text { growth. }\end{array}$ & $\begin{array}{l}\text { Increased the superoxide } \\
\text { dismutases, glutathione } \\
\text { peroxidase, interleukin-2, and } \\
\text { indices of spleen and thymus } \\
\text { in Kunming mice. }\end{array}$ & [33] \\
\hline $\begin{array}{l}\text { Breast } \\
\text { cancer }\end{array}$ & $\begin{array}{c}\text { Aged } \\
\text { garlic (AG) }\end{array}$ & MCF-7 & $\begin{array}{c}\text { Exhibited a } \\
\text { chemosensitizing } \\
\text { effect. }\end{array}$ & $\begin{array}{c}\text { Induction of apoptosis, } \\
\text { enhanced intracellular DOX } \\
\text { accumulation, inhibition of } \\
\text { P-gp activity. }\end{array}$ & [58] \\
\hline $\begin{array}{l}\text { Liver } \\
\text { cancer }\end{array}$ & SAMC & HepG2 cells & $\begin{array}{l}\text { SAMC promoted MAPK } \\
\text { inhibitor-induced } \\
\text { apoptosis by activating } \\
\text { the TGF- } \beta \\
\text { signaling pathway. }\end{array}$ & $\begin{array}{l}\text { Activated TGF- } \beta 1, \text { T } \beta \text { RII, } \\
\text { psmad } 2 / 3, \text { smad } 4 \text { and smad7 } \\
\text { signaling. }\end{array}$ & [179] \\
\hline $\begin{array}{l}\text { Bladder } \\
\text { cancer }\end{array}$ & SAMC & MGH-U1 cells & $\begin{array}{l}\text { SAMC inhibited the } \\
\text { survival, invasion, and } \\
\text { migration of bladder } \\
\text { cancer cells. }\end{array}$ & Inactivated Id-1 pathway. & [180] \\
\hline $\begin{array}{l}\text { Thyroid } \\
\text { cancer }\end{array}$ & SAMC & HPACC-8305C & $\begin{array}{l}\text { SAMC inhibited the } \\
\text { growth of } \\
\text { HPACC-8305C cells. }\end{array}$ & $\begin{array}{c}\text { Induction of apoptotic cell } \\
\text { death. Inhibited } \\
\text { telomerase activity. }\end{array}$ & [168] \\
\hline $\begin{array}{l}\text { Lung } \\
\text { cancer }\end{array}$ & $\begin{array}{l}\text { Black } \\
\text { garlic }\end{array}$ & Lewis cells & $\begin{array}{l}\text { Inhibited the growth of } \\
\text { lung cancer cells. }\end{array}$ & $\begin{array}{l}\text { Affected the expression of Bax } \\
\text { and BCL-2 }\end{array}$ & [169] \\
\hline $\begin{array}{l}\text { Ovarian } \\
\text { cancer }\end{array}$ & SAMC & $\begin{array}{l}\text { HO8910, HO8910PM, } \\
\text { and SKOV3 }\end{array}$ & $\begin{array}{l}\text { SAMC suppressed both } \\
\text { the proliferation and } \\
\text { distant } \\
\text { metastasis of epithelial } \\
\text { ovarian cancers cells. }\end{array}$ & $\begin{array}{l}\text { Down-regulated the survivin } \\
\text { gene in HO8910PM cells with } \\
\text { small interference RNA } \\
\text { (siRNA). Decreased } \\
\text { invasiveness of tumor cells. }\end{array}$ & [181] \\
\hline
\end{tabular}

cdk1: cyclin-dependent kinase 1; NF- $\kappa \beta$ : nuclear factor- $\kappa \beta$; GSH: glutathione; MMP-2: matrix metalloproteinase-2; MMP-9: matrix metalloproteinase-9; DOX- doxorubicin; P-gp: P-glycoprotein; MAPK: mitogen-activated protein kinase; TGF- $\beta 1$ : transforming growth factor beta 1; T $\beta$ RII: type II TGF- $\beta$ receptor; $p$-samd 2/3: phosphorylated- suppressor of mothers against decapentaplegic $2 / 3$; smad 4: suppressor of mothers against decapentaplegic homolog 4; smad7: suppressor of mothers against decapentaplegic homolog 7; Id-1: inhibitor of differentiation-1; BCL-2: B-cell lymphoma 2; Bax: BCL-2-associated X protein. 


\section{Conclusions and Future Perspectives}

Although BG has been recognized in Asia since ancient times, there is a growing interest in its intake around the world because of its singular organoleptic qualities and bioactive effects. The questionable origin of BG and the lack of a standard technique of preparation has led to the lack of a quality index, which makes it challenging to obtain a standardized BG product. There are several aspects that can directly affect BG's sensory and nutritional properties, including processing technologies and processing variables such as time, temperature, humidity, $\mathrm{pH}$, as well as type of pre-treatment. In particular, some processes and reactions are critical to the properties of the final BG, notably the Millard reaction. Moreover, the interactions between garlic compounds as well as microbes during the aging process also affect the properties of BG. As reported in this review, a large number of studies have been conducted to prepare the BG under different processing conditions. As a result, variations in phytochemical contents of BG were also noticed after the Millard reaction. It is clear from this review that more research is needed to find out the optimal conditions for BG processing, the roles of key compounds on biological properties, as well as to establish a clear relation between chemical and sensory characteristics of BG.

Numerous pre-clinical and clinical studies have provided solid evidence to support the therapeutic potential of BG consumption in various preparations in the treatment of various human diseases. The aged garlic extract is the most studied formulation among the available preparation and has shown effective pharmacological activity. The present review suggests that the therapeutic effects of BG are mainly attributed to its antioxidant, immunomodulatory, anti-inflammatory, anticancer, anti-diabetic, anti-obesity, digestive system protective, hepatoprotective, cardiovascular protective, neuroprotective, and nephroprotective activities. BG's therapeutic benefits appear to be mediated by the regulation of several signaling molecules. However, in many cases, the underlying mechanisms are unknown because of the complexity of the disorders. Indeed, there are only very few and inconsistent outcomes from human studies, presumably because of variances in BG preparations, unknown active substances, and their bioavailability, as well as small sample size. Therefore, the hypothesized in vitro and in vivo animal studies should be further verified in human studies to provide a deeper understanding of BG's therapeutic potential.

Funding: This research received no external funding.

Conflicts of Interest: The authors declare no conflict of interest.

$\begin{array}{ll}\text { Abbreviations } \\ \text { BG } & \text { black garlic } \\ \text { Temp. } & \text { temperature } \\ \text { 5-HMF } & \text { 5-Hydroxymethylfurfural } \\ \text { SAC } & \text { s-allyl cysteine } \\ \text { FG } & \text { fresh garlic } \\ \text { BG } & \text { black garlic } \\ \text { DM } & \text { dry matter } \\ \text { DW } & \text { dry weight } \\ \text { FM } & \text { fresh matter } \\ \text { GAE } & \text { gallic acid equivalent } \\ \text { QE } & \text { quercetin equivalent } \\ \text { RE } & \text { rutin equivalent } \\ \text { CAE } & \text { catechin equivalents } \\ \text { OD } & \text { optical density } \\ \text { SAC } & \text { s-allyl cysteine } \\ \text { NF- } \beta & \text { nuclear factor- } \beta \\ \text { HDL-C } & \text { high-density lipoprotein cholesterol } \\ \text { GOT } & \text { glutamic oxaloacetic transaminase } \\ \text { GPT } & \text { glutamic pyruvic transaminase }\end{array}$




\begin{tabular}{|c|c|}
\hline$\gamma-\mathrm{GTP}$ & $\gamma$-glutamyl transpeptidase \\
\hline SOD & superoxide dismutase \\
\hline GSH-Px & glutathione peroxidase \\
\hline CAT & catalase \\
\hline $\mathrm{GHb}$ & glycated hemoglobin \\
\hline STZ & streptozotocin \\
\hline TBARS & thiobarbituric acid reactive substances \\
\hline TNF- $\alpha$ & tumor necrosis factor- $\alpha$ \\
\hline IL-6 & interleukin-6 \\
\hline LDL & low-density lipoprotein \\
\hline TG & triglyceride \\
\hline TC & total cholesterol \\
\hline $\begin{array}{l}\mathrm{C} / \mathrm{EBP} \alpha \\
\mathrm{UCP} 1\end{array}$ & $\begin{array}{l}\text { CCAAT/enhancer-binding protein } \alpha \\
\text { uncoupling protein } 1\end{array}$ \\
\hline CPT1 & carnitine palmitoyl transferase 1 \\
\hline $\mathrm{ACO}$ & acyl-coenzyme A oxidase \\
\hline HSL & hormone sensitive lipase \\
\hline ATGL & adipose triglyceride lipase \\
\hline Sirt1 & sirtuin 1 \\
\hline FOXO1 & forkhead box $\mathrm{O} 1$ \\
\hline $\operatorname{PPAR} \alpha$ & peroxisome proliferator-activated receptor $c$ \\
\hline AMPK & AMP-activated protein kinase \\
\hline SREBP-1C & sterol regulatory element binding protein-1c \\
\hline $\mathrm{ACC}$ & acetyl-CoA carboxylase \\
\hline FAS & fatty acid synthase \\
\hline SCD1 & stearoyl-CoA desaturase-1 \\
\hline HFD & high-fat diet \\
\hline LPO & lipid peroxidation \\
\hline GSSG & glutathione disulfide \\
\hline ADP & adenosine diphosphate \\
\hline RAS & renin-angiotensin system \\
\hline OFRs & oxygen free radicals \\
\hline PVN & paraventricular nucleus \\
\hline CSAR & cardiac sympathetic afferent reflex \\
\hline $\mathrm{ACE}$ & angiotensin-converting enzyme \\
\hline Fru-Arg & N-(1-deoxy-D-fructos-1-yl)-l-arginine \\
\hline Fru-Met & N-(1-deoxy-D-fructos-1-yl)-1-methionine \\
\hline CAC & coronary artery calcification \\
\hline CRP & c-reactive protein \\
\hline EAT & epicardial adipose tissue \\
\hline PAT & pericardial adipose tissue \\
\hline $\mathrm{PaAT}$ & periaortic adipose tissue \\
\hline SAT & subcutaneous adipose tissue \\
\hline $\operatorname{IgG}$ & immunoglobulin G \\
\hline $\operatorname{Ig} M$ & immunoglobulin $\mathrm{M}$ \\
\hline MDA-LDL & malondialdehyde-low-density lipoprotein \\
\hline HDL & high-density lipoprotein \\
\hline OxPL/apoB & oxidized phospholipids/apolipoprotein B \\
\hline LP & lipoprotein \\
\hline GAD & glutamate decarboxylase \\
\hline VGLUT1 & vesicular glutamate transporter 1 \\
\hline GSK-3 $\beta$ & glycogen synthase kinase 3 beta \\
\hline $\operatorname{sAPP} \alpha$ & soluble amyloid precursor protein $\alpha$ \\
\hline $\mathrm{A} \beta$ & $\beta$-amyloid \\
\hline
\end{tabular}




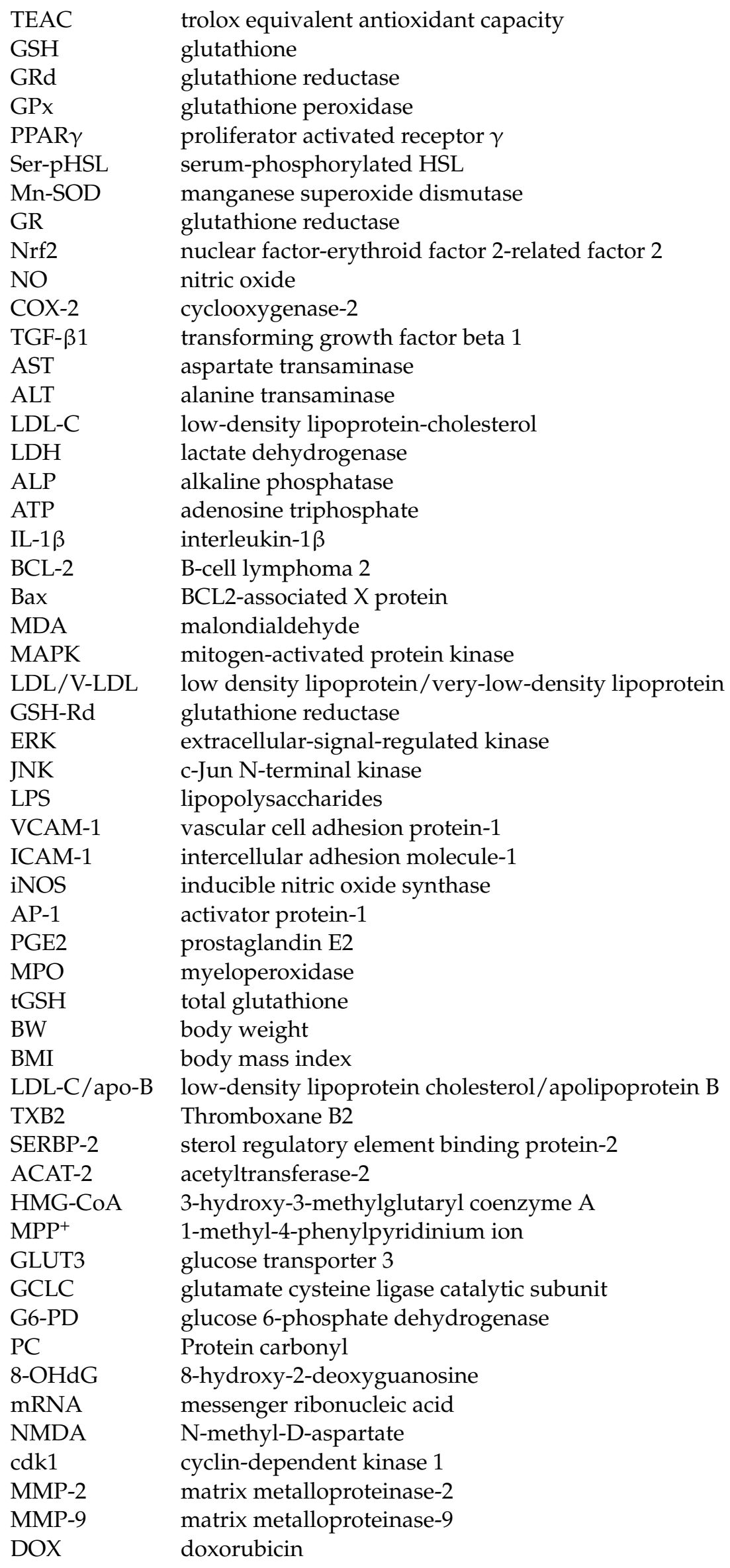




$\begin{array}{ll}\text { P-gp } & \text { p-glycoprotein } \\ \text { TGF- } \beta 1 & \text { transforming growth factor beta } 1 \\ \text { T } \beta \text { RII } & \text { type II TGF- } \beta \text { receptor } \\ \text { p-samd 2/3 } & \text { phosphorylated-suppressor of mothers against decapentaplegic 2/3 } \\ \text { smad } 4 & \text { suppressor of mothers against decapentaplegic homolog } 4 \\ \text { smad7 } & \text { suppressor of mothers against decapentaplegic homolog } 7 \\ \text { Id-1 } & \text { inhibitor of differentiation-1 } \\ \text { SNAP25 } & \text { synaptosomal associated protein of 25 } \mathrm{kDa} \\ \text { ABTS } & \text { 2,2-azino-bis (3-ethylbenzothiazoline-6-sulfonic acid }\end{array}$

\section{References}

1. Doré, J.; Blottière, H. The influence of diet on the gut microbiota and its consequences for health. Curr. Opin. Biotechnol. 2015, 32, 195-199. [CrossRef]

2. Mozaffarian, D. Dietary and policy priorities for cardiovascular disease, diabetes, and obesity: A comprehensive review. Circulation 2016, 133, 187-225. [CrossRef] [PubMed]

3. Slavin, J.L.; Lloyd, B. Health benefits of fruits and vegetables. Adv. Nutr. 2012, 3, 506-516. [CrossRef] [PubMed]

4. Kaparapu, J.; Pragada, P.M.; Geddada, M.N.R. Fruits and Vegetables and its Nutritional Benefits. In Functional Foods Nutraceuticals; Springer: Berlin/Heidelberg, Germany, 2020; pp. 241-260.

5. Del Rio-Celestino, M.; Font, R. The health benefits of fruits and vegetables. Foods 2020, 9, 369. [CrossRef] [PubMed]

6. Diretto, G.; Rubio-Moraga, A.; Argandoña, J.; Castillo, P.; Gómez-Gómez, L.; Ahrazem, O. Tissue-specific accumulation of sulfur compounds and saponins in different parts of garlic cloves from purple and white ecotypes. Molecules 2017, 22, 1359. [CrossRef]

7. Liyanagamage, D.; Jayasinghe, S.; Attanayake, A.P.; Karunaratne, V. Medicinal plants in management of diabetes mellitus: An overview. Ceylon J. Sci. 2020, 49, 3-11. [CrossRef]

8. Bose, S.; Laha, B.; Banerjee, S. Quantification of allicin by high performance liquid chromatography-ultraviolet analysis with effect of post-ultrasonic sound and microwave radiation on fresh garlic cloves. Pharmacogn. Mag. 2014, 10, S288-S293. [CrossRef]

9. Qu, Z.; Mossine, V.V.; Cui, J.; Sun, G.Y.; Gu, Z. Protective effects of AGE and its components on neuroinflammation and neurodegeneration. Neuromolecular Med. 2016, 18, 474-482. [CrossRef]

10. Szychowski, K.; Rybczynska-Tkaczyk, K.; Gawel-Beben, K.; Swieca, M.; Karas, M.; Jakubczyk, A.; Matysiak-Kucharek, M.; Binduga, U.; Gminski, J. Characterization of active compounds of different garlic (Allium sativum L.) cultivars. Pol. J. Food Nutr. Sci. 2018, 68, 73-81. [CrossRef]

11. Ryu, J.H.; Kang, D. Physicochemical properties, biological activity, health benefits, and general limitations of aged black garlic: A review. Molecules 2017, 22, 919. [CrossRef]

12. Tanamai, J.; Veeramanomai, S.; Indrakosas, N.; Indrakosas, N. The efficacy of cholesterol-lowering action and side effects of garlic enteric coated tablets in man. J. Med. Assoc. Thail. 2004, 87, 1156-1161.

13. Mathew, B.C.; Biju, R.S. Neuroprotective effects of garlic a review. Libyan J. Med. 2008, 3, 23-33. [PubMed]

14. Santos, F.C.C.; Carvalho, N.U.M. Tintura alcoólica de alho (Allium sativum) sobre endoparasitas gastrintestinais de ovinos. Ciência Anim. Bras. 2014, 15, 115-118. [CrossRef]

15. Li, M.; Yan, Y.; Yu, Q.; Deng, Y.; Wu, D.; Wang, Y.; Ge, Y.; Li, S.; Zhao, J. Comparison of immunomodulatory effects of fresh garlic and black garlic polysaccharides on RAW 264.7 Macrophages. J. Food Sci. 2017, 82, 765-771. [CrossRef]

16. Bae, S.E.; Cho, S.Y.; Won, Y.D.; Lee, S.H.; Park, H.J. Changes in S-allyl cysteine contents and physicochemical properties of black garlic during heat treatment. LWT-Food Sci. Technol. 2015, 55, 397-402. [CrossRef]

17. Kimura, S.; Tung, Y.-C.; Pan, M.-H.; Su, N.-W.; Lai, Y.-J.; Cheng, K.-C. Black garlic: A critical review of its production, bioactivity, and application. J. Food Drug Anal. 2017, 25, 62-70. [CrossRef] [PubMed]

18. Martinez-Casas, L.; Lage-Yusty, M.; López-Hernández, J. Changes in the aromatic profile, sugars, and bioactive compounds when purple garlic is transformed into black garlic. J. Agric. Food Chem. 2017, 65, 10804-10811. [CrossRef]

19. Amagase, H.; Petesch, B.L.; Matsuura, H.; Kasuga, S.; Itakura, Y. Intake of garlic and its bioactive components. J. Nutr. 2001, 131, 955S-962S. [CrossRef]

20. Jeong, Y.; Ryu, J.; Shin, J.; Kang, M.; Kang, J.; Han, J.; Kang, D. Comparison of anti-oxidant and anti-inflammatory effects between fresh and aged black garlic extracts. Molecules 2016, 21, 430. [CrossRef]

21. Tak, H.-M.; Kang, M.-J.; Kim, K.M.; Kang, D.; Han, S.; Shin, J.-H. Anti-inflammatory activities of fermented black garlic. J. Korean Soc. Food Sci. Nutr. 2014, 43, 1527-1534. [CrossRef]

22. Kim, D.; Kang, M.J.; Hong, S.S.; Choi, Y.-H.; Shin, J.H. Antiinflammatory effects of functionally active compounds isolated from aged black garlic. Phyther. Res. 2017, 31, 53-61. [CrossRef] [PubMed]

23. Zhang, J.; Jilg, H. Antioxidant and anti-inflammatory activities of black garlic extracts. J. Food Saf. Qual. 2017, 8, $2635-2643$.

24. Wu, J.; Liu, Y.; Dou, Z.; Wu, T.; Liu, R.; Sui, W.; Jin, Y.; Zhang, M. Black garlic melanoidins prevent obesity, reduce serum LPS levels and modulate the gut microbiota composition in high-fat diet-induced obese C57BL/6J mice. Food Funct. 2020, 11, 9585-9598. [CrossRef] [PubMed] 
25. Chang, W.; Shiau, D.; Cheng, M.; Tseng, C.; Chen, C.; Wu, M.; Hsu, C. Black garlic ameliorates obesity induced by a high-fat diet in rats. J. Food Nutr. Res. 2017, 5, 736-741. [CrossRef]

26. Chung, S.Y.; Han, K.-H.; Bae, S.-H.; Han, S.H.; Lee, Y.K. Effects of the Fermented Black Garlic Extract on Lipid Metabolism and Hepatoprotection in Mice. Korean J. Food Nutr. 2020, 33, 17-26.

27. Shin, J.; Lee, C.; Oh, S.; Yun, J.; Kang, M.; Han, S.; Park, H.; Jung, J.; Chung, Y.; Kang, J. Hepatoprotective effect of aged black garlic extract in rodents. Toxicol. Res. 2014, 30, 49-54. [CrossRef]

28. Tsai, J.; Chen, Y.; Wu, J.; Cheng, K.; Lai, P.; Liu, K.; Lin, Y.; Huang, Y.; Hsieh, C. Extracts from fermented black garlic exhibit a hepatoprotective effect on acute hepatic injury. Molecules 2019, 24, 1112. [CrossRef]

29. Kim, I.; Kim, J.; Hwang, Y.; Hwang, K.; Om, A.; Kim, J.; Cho, K. The beneficial effects of aged black garlic extract on obesity and hyperlipidemia in rats fed a high-fat diet. J. Med. Plants Res. 2011, 5, 3159-3168.

30. Seo, Y.-J.; Gweon, O.-C.; Im, J.-E.; Lee, Y.-M.; Kang, M.-J.; Kim, J.-I. Effect of garlic and aged black garlic on hyperglycemia and dyslipidemia in animal model of type 2 diabetes mellitus. Prev. Nutr. Food Sci. 2009, 14, 1-7. [CrossRef]

31. Alkreathy, H.M. Potential Anticancer Effects of Aged Garlic Extract and its Water-soluble Organosulfur Compounds. J. Pharm. Res. Int. 2020, 32, 108-121. [CrossRef]

32. Dong, M.; Yang, G.; Liu, H.; Liu, X.; Lin, S.; Sun, D.; Wang, Y. Aged black garlic extract inhibits HT29 colon cancer cell growth via the PI3K/Akt signaling pathway. Biomed. Rep. 2014, 2, 250-254. [CrossRef] [PubMed]

33. Wang, X.; Jiao, F.; Wang, Q.; Qang, J.; Yang, K.; Hu, R.; Liu, H.; Wang, H.; Wang, Y. Aged black garlic extract induces inhibition of gastric cancer cell growth in vitro and in vivo. Mol. Med. Rep. 2012, 5, 66-72. [CrossRef]

34. Yoo, J.-M.; Sok, D.-E.; Kim, M.R. Anti-allergic action of aged black garlic extract in RBL-2H3 cells and passive cutaneous anaphylaxis reaction in mice. J. Med. Food. 2014, 17, 92-102. [CrossRef] [PubMed]

35. Kim, J.H.; Nam, S.H.; Rico, C.W.; Kang, M.Y. A comparative study on the antioxidative and anti-allergic activities of fresh and aged black garlic extracts. Int. J. Food Sci. Technol. 2012, 47, 1176-1182. [CrossRef]

36. Venkatesh, Y.P. Immunomodulatory attributes of aged garlic extract and its components. In Immunology; Elsevier: Amsterdam, The Netherlands, 2018; pp. 203-224.

37. Garcia-Villalón, A.L.; Amor, S.; Monge, L.; Fernández, N.; Prodanov, M.; Muñoz, M.; Inarejos-Garcíac, A.M.; Granado, M. In vitro studies of an aged black garlic extract enriched in S-allylcysteine and polyphenols with cardioprotective effects. J. Funct. Foods. 2016, 27, 189-200. [CrossRef]

38. Zhang, X.; Shi, Y.; Wang, L.; Li, X.; Zhang, S.; Wang, X.; Jin, M.; Hsiao, C.-D.; Lin, H.; Han, L.; et al. Metabolomics for Biomarker Discovery in Fermented Black Garlic and Potential Bioprotective Responses against Cardiovascular Diseases. J. Agric. Food Chem. 2019, 67, 12191-12198. [CrossRef] [PubMed]

39. Song, H.; Cui, J.; Mossine, V.V.; Greenlief, C.M.; Fritsche, K.; Sun, G.Y.; Gu, Z. Bioactive components from garlic on brain resiliency against neuroinflammation and neurodegeneration. Exp. Ther. Med. 2020, 19, 1554-1559. [CrossRef] [PubMed]

40. Choi, D.-J.; Lee, S.-J.; Kang, M.-J.; Cho, H.-S.; Sung, N.-J.; Shin, J.-H. Physicochemical characteristics of black garlic (Allium sativum L.). J. Korean Soc. Food Sci. Nutr. 2008, 37, 465-471. [CrossRef]

41. Zhang, X.; Li, N.; Lu, X.; Liu, P.; Qiao, X. Effects of temperature on the quality of black garlic. J. Sci. Food Agric. 2016, 96, 2366-2372. [CrossRef]

42. Sun, Y.-E.; Wang, W. Changes in nutritional and bio-functional compounds and antioxidant capacity during black garlic processing. J. Food Sci. Technol. 2018, 55, 479-488. [CrossRef]

43. Shin, J.-H.; Choi, D.-J.; Lee, S.-J.; Cha, J.-Y.; Kim, J.-G.; Sung, N.-J. Changes of physicochemical components and antioxidant activity of garlic during its processing. J. Life Sci. 2008, 18, 1123-1131. [CrossRef]

44. Toledano-Medina, M.A.; Pérez-Aparicio, J.; Moreno-Rojas, R.; Merinas-Amo, T. Evolution of some physicochemical and antioxidant properties of black garlic whole bulbs and peeled cloves. Food Chem. 2016, 199, 135-139. [CrossRef] [PubMed]

45. Wang, D.; Feng, Y.; Liu, J.; Yan, J.; Wang, M.; Sasaki, J.-I.; Lu, C. Black garlic (Allium sativum) extracts enhance the immune system. Med. Aromat. Plant Sci. Biotechnol. 2010, 4, 37-40.

46. Choi, I.S.; Cha, H.S.; Lee, Y.S. Physicochemical and antioxidant properties of black garlic. Molecules 2014, 19, 16811-16823. [CrossRef] [PubMed]

47. Lee, H.-H.; Kim, I.-J.; Kang, S.-T.; Kim, Y.-H.; Lee, J.-O.; Ryu, C.-H. Development of black garlic Yakju and its antioxidant activity. Korean J. Food Sci. Technol. 2010, 42, 69-74.

48. Andersen, R.; Sørensen, A. An enzymatic method for the determination of fructans in foods and food products. Eur. Food Res. Technol. 1999, 210, 148-152. [CrossRef]

49. Upadhyay, R.K. Nutritional and therapeutic potential of Allium vegetables. J Nutr Ther. 2017, 6, 18-37. [CrossRef]

50. Cheong, K.L.; Yan, F.; Huang, X. Enymologic characterization of garlic fructan exohydrolase. J. Food Biochem. 2012, 36, 248-253. [CrossRef]

51. Liang, T.; Wei, F.; Lu, Y.; Kodani, Y.; Nakada, M.; Miyakawa, T.; Tanokura, M. Comprehensive NMR analysis of compositional changes of black garlic during thermal processing. J. Agric. Food Chem. 2015, 63, 683-691. [CrossRef] [PubMed]

52. Yuan, H.; Sun, L.; Chen, M.; Wang, J. An analysis of the changes on intermediate products during the thermal processing of black garlic. Food Chem. 2015, 23, 56-61. [CrossRef]

53. Lei, M.-M.; Xu, M.-Y.; Zhang, Z.-S.; Zhang, M.; Gao, Y.-F. The analysis of saccharide in black garlic and its antioxidant activity. Adv. J. Food Sci. Technol. 2014, 6, 755-760. [CrossRef] 
54. Molina-Calle, M.; de Medina, V.; Calderón-Santiago, M.; Priego-Capote, F.; de Castro, M.D. Untargeted analysis to monitor metabolic changes of garlic along heat treatment by LC-QTOF MS/MS. Electrophoresis 2017, 38, 2349-2360. [CrossRef] [PubMed]

55. Lu, X.; Li, N.; Qiao, X.; Qiu, Z. Effects of thermal treatment on polysaccharide degradation during black garlic processing. LWT-Food Sci. Technol. 2018, 95, 223-229. [CrossRef]

56. Qiu, Z.; Lu, X.; Li, N.; Zhang, M.; Qiao, X. Characterization of garlic endophytes isolated from the black garlic processing. Microbiologyopen 2018, 7, 1-11. [CrossRef]

57. Kamanna, V.S.; Chandrasekhara, N. Fatty acid composition of garlic (Allium sativum Linnaeus) lipids. J. Am. Oil Chem. Soc. 1980, 57, 175-176. [CrossRef]

58. Lu, X. Study on Formation Mechanism and Function of Black Garlic Oligosaccharides. Doctoral Thesis, Shandong Agriculture University, Taian, China, 2017.

59. Zamora, R.; Hidalgo, F.J. Coordinate contribution of lipid oxidation and Maillard reaction to the nonenzymatic food browning. Crit. Rev. Food Sci. Nutr. 2005, 45, 49-59. [CrossRef]

60. Lee, J.; Harnly, J.M. Free amino acid and cysteine sulfoxide composition of 11 garlic (Allium sativum L.) cultivars by gas chromatography with flame ionization and mass selective detection. J. Agric. Food Chem. 2005, 53, 9100-9104. [CrossRef] [PubMed]

61. Hwang, I.G.; Kim, H.Y.; Woo, K.S.; Lee, J.; Jeong, H.S. Biological activities of Maillard reaction products (MRPs) in a sugar-amino acid model system. Food Chem. 2011, 126, 221-227. [CrossRef]

62. Qiu, Z.; Zheng, Z.; Zhang, B.; Sun-Waterhouse, D.; Qiao, X. Formation, nutritional value, and enhancement of characteristic components in black garlic: A review for maximizing the goodness to humans. Compr. Rev. Food Sci. Food Saf. 2020, 19, 801-834. [CrossRef] [PubMed]

63. Sato, E.; Kohno, M.; Hamano, H.; Niwano, Y. Increased anti-oxidative potency of garlic by spontaneous short-term fermentation. Plant Foods Hum. Nutr. 2006, 61, 157-160. [CrossRef]

64. Kodera, Y.; Suzuki, A.; Imada, O.; Kasuga, S.; Sumioka, I.; Kanezawa, A.; Taru, N.; Fujikawa, M.; Nagae, S.; Masamoto, K. Physical, chemical, and biological properties of S-allylcysteine, an amino acid derived from garlic. J. Agric. Food Chem. 2002, 50, 622-632. [CrossRef] [PubMed]

65. Li, N.; Lu, X.; Pei, H.; Qiao, X. Effect of freezing pretreatment on the processing time and quality of black garlic. J. Food Process Eng. 2015, 38, 329-335. [CrossRef]

66. Ritota, M.; Casciani, L.; Han, B.Z.; Cozzolino, S.; Leita, L.; Sequi, P.; Valentini, M. Traceability of Italian garlic (Allium sativum L.) by means of HRMAS-NMR spectroscopy and multivariate data analysis. Food Chem. 2012, 135, 684-693. [CrossRef] [PubMed]

67. Blecker, C.; Fougnies, C.; van Herck, J.-C.; Chevalier, J.-P.; Paquot, M. Kinetic study of the acid hydrolysis of various oligofructose samples. J. Agric. Food Chem. 2002, 50, 1602-1607. [CrossRef]

68. Rahman, M.S. Handbook of Food Preservation; CRC Press: Boca Raton, FL, USA, 2007.

69. Limacher, A.; Kerler, J.; Davidek, T.; Schmalzried, F.; Blank, I. Formation of furan and methylfuran by Maillard-type reactions in model systems and food. J. Agric. Food Chem. 2008, 56, 3639-3647. [CrossRef]

70. Kim, J.-S.; Kang, O.-J.; Gweon, O.-C. Changes in the content of fat-and water-soluble vitamins in black garlic at the different thermal processing steps. Food Sci. Biotechnol. 2013, 22, 283-287. [CrossRef]

71. Rayman, M.P. Food-chain selenium and human health: Emphasis on intake. Br. J. Nutr. 2008, 100, 254-268. [CrossRef]

72. Houston, M.C.; Harper, K.J. Potassium, magnesium, and calcium: Their role in both the cause and treatment of hypertension. J. Clin. Hypertens. 2008, 10, 3-11. [CrossRef]

73. Kang, O.-J. Physicochemical characteristics of black garlic after different thermal processing steps. Prev. Nutr. Food Sci. 2016, 21, 348-354. [CrossRef] [PubMed]

74. Shinkawa, H.; Takemura, S.; Minamiyama, Y.; Kodai, S.; Tsukioka, T.; Osada-Oka, M.; Kubo, S.; Okada, S.; Suehiro, S. Sallylcysteine is effective as a chemopreventive agent against porcine serum-induced hepatic fibrosis in rats. Osaka City Med. J. 2009, 55, 61-69. [PubMed]

75. Yang, P.; Song, H.; Wang, L.; Jing, H. Characterization of key aroma-active compounds in black garlic by sensory-directed flavor analysis. J. Agric. Food Chem. 2019, 67, 7926-7934. [CrossRef]

76. Kang, O.-J. Evaluation of melanoidins formed from black garlic after different thermal processing steps. Prev. Nutr. Food Sci. 2016, 21, 398. [CrossRef] [PubMed]

77. Rios-Rios, K.L.; Montilla, A.; Olano, A.; Villamiel, M. Physicochemical changes and sensorial properties during black garlic elaboration: A review. Trends Food Sci. Technol. 2019, 88, 459-467. [CrossRef]

78. Huang, M.L.; Jiang, N.T.; Jiang, X.M. Colour, Taste, and Odor Chemistry of Food; China Light Industry Press: Beijing, China, 1984.

79. Xiaoming, L.; Li, N.; Qiao, X.; Qiu, Z.; Liu, P. Composition analysis and antioxidant properties of black garlic extract. J. Food Drug Anal. 2016, 10, 340-349.

80. Kim, I.-D.; Park, Y.-S.; Park, J.-J.; Dhungana, S.K.; Shin, D.-H. Physicochemical and antioxidant properties of garlic (A. sativum) prepared by different heat treatment conditions. Korean J. Food Sci. Technol. 2019, 51, 452-458.

81. Liu, J.; Zhang, G.; Cong, X.; Wen, C. Black garlic improves heart function in patients with coronary heart disease by improving circulating antioxidant levels. Front. Physiol. 2018, 9, 1435-1445. [CrossRef]

82. Kim, J.-S.; Kang, O.-J.; Gweon, O.-C. Comparison of phenolic acids and flavonoids in black garlic at different thermal processing steps. J. Funct. Foods. 2013, 5, 80-86. [CrossRef] 
83. Setiyoningrum, F.; Priadi, G.; Afiati, F.; Herlina, N.; Solikhin, A. Composition of spontaneous black garlic fermentation in a water bath. Food Sci. Technol. 2021. [CrossRef]

84. Shin, J.-H.; Choi, D.-J.; Lee, S.-J.; Cha, J.-Y.; Sung, N.-J. Antioxidant activity of black garlic (Allium sativum L.). J. Korean Soc. Food Sci. Nutr. 2008, 37, 965-971. [CrossRef]

85. Kim, M.-S.; Kim, M.-J.; Bang, W.-S.; Kim, K.-S.; Park, S.-S. Determination of s-allyl-1-cystein, diallyl disulfide, and total amino acids of black garlic after spontaneous short-term fermentation. J. Korean Soc. Food Sci. Nutr. 2012, 41, 661-665. [CrossRef]

86. Al-Shehri, S.A. Efficacy of black garlic extract on anti-tumor and anti-oxidant activity enhancement in rats. Clin. Nutr. Open Sci. 2021, 36, 126-139. [CrossRef]

87. Park, S.H.; Lee, H.; Kim, H.S.; Kim, Y.-R.; Noh, S.H. Optimum conditions for S-allyl-(L)-cysteine accumulation in aged garlic by RSM. Food Sci. Biotechnol. 2014, 23, 717-722. [CrossRef]

88. Thao, H.P.; Tuan, N.D.; Zemann, A. Quantitative analysis of S-Allylcysteine in black garlic via Ultra-High-Performance Liquid Chromatography-Tandem Mass Spectrometry. Syst. Rev. Pharm. 2019, 10, 161-166.

89. Kim, J.H.; Yu, S.H.; Cho, Y.J.; Pan, J.H.; Cho, H.T.; Kim, J.H.; Bong, H.; Lee, Y.; Chang, M.H.; Jeong, Y.J. Preparation of Sallylcysteine-enriched black garlic juice and its antidiabetic effects in streptozotocin-induced insulin-deficient mice. J. Agric. Food Chem. 2017, 65, 358-363. [CrossRef]

90. Sasaki, J.I.; Lu, C.; Machiya, E.; Tanahashi, M.; Hamada, K. Processed black garlic (Allium sativum) extracts enhance anti-tumor potency against mouse tumors. Energy 2007, 227, 278-281.

91. Sato, E.; Kohno, M.; Niwano, Y. Increased level of tetrahydro- $\beta$-carboline derivatives in short-term fermented garlic. Plant Foods Hum. Nutr. 2006, 61, 175-178. [CrossRef] [PubMed]

92. Zhang, Z.; Lei, M.; Liu, R.; Gao, Y.; Xu, M.; Zhang, M. Evaluation of alliin, saccharide contents and antioxidant activities of black garlic during thermal processing. J. Food Biochem. 2015, 39, 39-47. [CrossRef]

93. Chen, Z.; Xu, M.; Wang, C.; Zhou, H.; Fan, L.; Huang, X. Thermolysis kinetics and thermal degradation compounds of alliin. Food Chem. 2017, 223, 25-30. [CrossRef]

94. Xu, X.; Miao, Y.; Chen, J.Y.; Zhang, Q.; Wang, J. Effective production of S-allyl-L-cysteine through a homogeneous reaction with activated endogenous - $\gamma$-glutamyltranspeptidase in garlic (Allium Sativum). J. Food Sci. Technol. 2015, 52, 1724-1729. [CrossRef]

95. Alberti, K.G.M.M.; Zimmet, P.Z. Definition, diagnosis and classification of diabetes mellitus and its complications. Part 1: Diagnosis and classification of diabetes mellitus. Provisional report of a WHO consultation. Diabet. Med. 1998, 15, 539-553. [CrossRef]

96. Thomson, M.; Al-Qattan, K.K.; Divya, J.S.; Ali, M. Anti-diabetic and anti-oxidant potential of aged garlic extract (AGE) in streptozotocin-induced diabetic rats. BMC Complement. Altern. Med. 2015, 16, 1-9.

97. Thomson, M.; Al-Qattan, K.; Jayasree, D.; Ali, M. Oral intake of aged garlic extract (AGE) ameliorates oxidative stress and other streptozotocin-induced diabetic complications in rats. Int. J. Pharmacol. 2017, 13, 593-602. [CrossRef]

98. Kang, M.-J.; Lee, S.J.; Sung, N.J.; Shin, J.-H. The effect of extract powder from fresh and black garlic on main components in serum and organs of streptozotocin-induced diabetic rats. J. Life Sci. 2013, 23, 432-442. [CrossRef]

99. Lee, Y.M.; Gweon, O.C.; Seo, Y.J.; Im, J.; Kang, M.J.; Kim, M.J.; Kim, J.I. Antioxidant effect of garlic and aged black garlic in animal model of type 2 diabetes mellitus. Nutr. Res. Pract. 2009, 3, 156. [CrossRef] [PubMed]

100. Si, L.; Lin, R.; Jia, Y.; Jian, W.; Yu, Q.; Wang, M.; Yang, S. Lactobacillus bulgaricus improves antioxidant capacity of black garlic in the prevention of gestational diabetes mellitus: A randomized control trial. Biosci. Rep. 2019, 39, BSR2018225. [CrossRef]

101. Lee, H.-M.; Seo, D.-Y.; Lee, S.-H.; Baek, Y.-H. Effects of exhaustive exercise and aged garlic extract supplementation on weight, adipose tissue mass, lipid profiles and oxidative stress in high fat diet induced obese rats. J. Life Sci. 2010, 20, 1889-1895. [CrossRef]

102. Lee, H.-S.; Lim, W.-C.; Lee, S.-J.; Lee, S.-H.; Lee, J.-H.; Cho, H.-Y. Antiobesity effect of garlic extract fermented by Lactobacillus plantarum BL2 in diet-induced obese mice. J. Med. Food. 2016, 19, 823-829. [CrossRef]

103. Seo, D.Y.; Lee, S.; Figueroa, A.; Kwak, Y.S.; Kim, N.; Rhee, B.D.; Ko, K.S.; Bang, H.S.; Beak, Y.H.; Han, J. Aged garlic extract enhances exercise-mediated improvement of metabolic parameters in high fat diet-induced obese rats. Nutr. Res. Pract. 2016, 6, 513. [CrossRef] [PubMed]

104. Xu, C.; Mathews, A.E.; Rodrigues, C.; Eudy, B.J.; Rowe, C.A.; O’Donoughue, A.; Percival, S.S. Aged garlic extract supplementation modifies inflammation and immunity of adults with obesity: A randomized, double-blind, placebo-controlled clinical trial. Clin. Nutr. ESPEN 2019, 24, 148-155. [CrossRef] [PubMed]

105. Chen, Y.-C.; Kao, T.-H.; Tseng, C.-Y.; Chang, W.-T.; Hsu, C.-L. Methanolic extract of black garlic ameliorates diet-induced obesity via regulating adipogenesis, adipokine biosynthesis, and lipolysis. J. Funct. Foods. 2014, 9, 98-108. [CrossRef]

106. Nam, H.; Jung, H.; Kim, Y.; Kim, B.; Kim, K.H.; Park, S.J.; Suh, J.G. Aged black garlic extract regulates lipid metabolism by inhibiting lipogenesis and promoting lipolysis in mature 3T3-L1 adipocytes. Food Sci. Biotechnol. 2018, 27, 575-579. [CrossRef]

107. Ahmad, M.S.; Pischetsrieder, M.; Ahmed, N. Aged garlic extract and S-allyl cysteine prevent formation of advanced glycation endproducts. Eur. J. Pharmacol. 2007, 561, 32-38. [CrossRef] [PubMed]

108. Maldonado, P.D.; Barrera, D.; Medina-Campos, O.N.; Hernández-Pando, R.; Ibarra-Rubio, M.E.; Pedraza-Chaverri, J. Aged garlic extract attenuates gentamicin induced renal damage and oxidative stress in rats. Life Sci. 2003, 73, 2543-2556. [CrossRef]

109. Shiju, T.M.; Rajesh, N.G.; Viswanathan, P. Renoprotective effect of aged garlic extract in streptozotocin-induced diabetic rats. Indian J. Pharmacol. 2013, 45, 18. [CrossRef] [PubMed] 
110. Albrakati, A. Aged garlic extract rescues ethephon-induced kidney damage by modulating oxidative stress, apoptosis, inflammation, and histopathological changes in rats. Environ. Sci. Pollut. Res. 2021, 28, 6818-6829. [CrossRef]

111. Lee, T.W.; Bae, E.; Kim, J.H.; Jang, H.N.; Cho, H.S.; Chang, S.H.; Park, D.J. The aqueous extract of aged black garlic ameliorates colistin-induced acute kidney injury in rats. Ren. Fail. 2019, 41, 24-33. [CrossRef] [PubMed]

112. Ansari, A.G.; Shaikh, A.A.; Memon, Z.A. Hepatoprotective Effect of Black Garlic Extract against Carbon Tetrachloride Induced Liver Injury in Rats. J. Peoples Univ. Med. Health Sci. 2014, 4, 86-91.

113. Kim, M.H.; Kim, M.J.; Lee, J.H.; Han, J.I.; Kim, J.H.; Sok, D.E.; Kim, M.R. Hepatoprotective effect of aged black garlic on chronic alcohol-induced liver injury in rats. J. Med. Food. 2011, 14, 732-738. [CrossRef]

114. Jiang, G.; Ramachandraiah, K.; Murtaza, M.A.; Wang, L.; Li, S.; Ameer, K. Synergistic effects of black ginseng and aged garlic extracts for the amelioration of nonalcoholic fatty liver disease (NAFLD) in mice. Food Sci. Nutr. 2021, 9, 3091-3099. [CrossRef]

115. Lee, H.S.; Lim, W.C.; Lee, S.J.; Lee, S.H.; Yu, H.J.; Lee, J.H.; Cho, H.Y. Hepatoprotective effects of lactic acid-fermented garlic extract against acetaminophen-induced acute liver injury in rats. Food Sci. Biotechnol. 2016, 25, 867-873. [CrossRef]

116. Park, C.; Gweon, O.-C.; Choi, Y.H.; Kim, J.-I. Aged black garlic inhibits cyclooxygenase-2 expression and prostaglandin E2 production by phorbol 12-myristate-13-acetate through inactivation of nuclear factor-kappab. Cancer Prev. Res. 2009, 14, 161-170.

117. Kim, H.K.; Choi, Y.W.; Lee, E.N.; Park, J.K.; Kim, S.G.; Park, D.J.; Kim, B.S.; Lim, Y.T.; Yoon, S. 5-Hydroxymethylfurfural from black garlic extract prevents TNF $\alpha$-induced monocytic cell adhesion to HUVECs by suppression of vascular cell adhesion molecule-1 expression, reactive oxygen species generation and NF-kB activation. Phyther. Res. 2011, 25, 965-974. [CrossRef]

118. Kong, F.; Lee, B.H.; Wei, K. 5-hydroxymethylfurfural mitigates lipopolysaccharide-stimulated inflammation via suppression of MAPK, NF-kB and mTOR activation in RAW 264.7 cells. Molecules 2019, 24, 275. [CrossRef] [PubMed]

119. Kim, K.H.; Park, J.K.; Choi, Y.W.; Kim, Y.H.; Lee, E.N.; Lee, J.R.; Kim, H.S.; Baek, S.Y.; Kim, B.S.; Lee, K.S. Hexane extract of aged black garlic reduces cell proliferation and attenuates the expression of ICAM-1 and VCAM-1 in TNF- $\alpha$-activated human endometrial stromal cells. Int. J. Mol. Med. 2013, 32, 67-78. [CrossRef]

120. Kim, M.J.; Yoo, Y.C.; Kim, H.J.; Shin, S.K.; Sohn, E.J.; Min, A.Y.; Sung, N.Y.; Kim, M.R. Aged black garlic exerts anti-inflammatory effects by decreasing no and proinflammatory cytokine production with less cytoxicity in LPS-stimulated raw 264.7 macrophages and LPS-induced septicemia mice. J. Med. Food. 2014, 17, 1057-1063. [CrossRef] [PubMed]

121. Chen, Y.-A.; Tsai, J.-C.; Cheng, K.-C.; Liu, K.-F.; Chang, C.-K.; Hsieh, C.-W. Extracts of black garlic exhibits gastrointestinal motility effect. Food Res. Int. 2018, 107, 102-109. [CrossRef]

122. Li, X.; Liu, R.; Zhang, M. Laxative effects of mixed black garlic beverage on BALB/c mice. China Food Addit. $2014,6,49-53$.

123. Kim, K.J.; Kim, S.H.; Shin, M.-R.; Kim, Y.J.; Park, H.-J.; Roh, S.-S. Protective effect of S-allyl cysteine-enriched black garlic on reflux esophagitis in rats via NF-kB signaling pathway. J. Funct. Foods. 2019, 58, 199-206. [CrossRef]

124. El-Ashmawy, N.E.; Khedr, E.G.; El-Bahrawy, H.A.; Selim, H.M. Gastroprotective effect of garlic in indomethacin induced gastric ulcer in rats. Nutrition 2016, 32, 849-854. [CrossRef] [PubMed]

125. Badr, G.M.; Al-Mulhim, J.A. The protective effect of aged garlic extract on nonsteroidal anti-inflammatory drug-induced gastric inflammations in male albino rats. Evidence-Based Complement. Altern. Med. 2014. [CrossRef]

126. Yüncü, M.; Eralp, A.; Celõk, A. Effect of aged garlic extract against methotrexate-induced damage to the small intestine in rats. Phyther. Res. Int. J. Devoted Pharmacol. Toxicol. Eval. Nat. Prod. Deriv. 2006, 20, 504-510. [CrossRef] [PubMed]

127. Blann, A.D. Platelets: The universal killer? Biochim. Biophys. Acta BBA Mol. Basis Dis. 2007, 1772, 715-717. [CrossRef]

128. Banerjee, S.K.; Maulik, S.K. Effect of garlic on cardiovascular disorders: A review. Nutr. J. 2002, 1, 1-14. [CrossRef]

129. Morihara, N.; Hino, A. Aged garlic extract suppresses platelet aggregation by changing the functional property of platelets. J. Nat. Med. 2017, 71, 249-256. [CrossRef] [PubMed]

130. Kim, H.-K. The Inhibiton Effects of Hypercholesterolemia and Platelet in Fermented and Non-Fermented Preparation of Garlic. Int. J. Internet Broadcast. Commun. 2019, 11, 1-10.

131. Irfan, M.; Kim, M.; Kim, K.S.; Kim, T.H.; Kim, S.D.; Hong, S.B.; Kim, H.K.; Rhee, M.H. Fermented garlic ameliorates hypercholesterolemia and inhibits platelet activation. Evidence-Based Complement. Altern. Med. 2019. [CrossRef]

132. Seo, D.Y.; Lee, S.R.; Kim, H.K.; Baek, Y.H.; Kwak, Y.S.; Ko, T.H.; Kim, N.; Rhee, B.D.; Ko, K.S.; Park, B.J.; et al. Independent beneficial effects of aged garlic extract intake with regular exercise on cardiovascular risk in postmenopausal women. Nutr. Res. Pract. 2012, 6, 226. [CrossRef]

133. Jung, E.S.; Park, S.H.; Choi, E.K.; Ryu, B.H.; Park, B.H.; Kim, D.S.; Kim, Y.G.; Chae, S.W. Reduction of blood lipid parameters by a 12-wk supplementation of aged black garlic: A randomized controlled trial. Nutrition 2014, 30, 1034-1039. [CrossRef]

134. Steiner, M.; Li, W. Aged garlic extract, a modulator of cardiovascular risk factors: A dose-finding study on the effects of AGE on platelet functions. J. Nutr. 2001, 131, 980S-984S. [CrossRef] [PubMed]

135. Rahman, K.; Billington, D. Dietary supplementation with aged garlic extract inhibits ADP-induced platelet aggregation in humans. J. Nutr. 2000, 130, 2662-2665. [CrossRef]

136. Gómez-Arbeláez, D.; Lahera, V.; Oubiña, P.; Valero-Muñoz, M.; Heras, N.D.L.; Rodríguez, Y.; García, R.G.; Camacho, P.A.; López-Jaramillo, P. Aged garlic extract improves adiponectin levels in subjects with metabolic syndrome: A double-blind, placebo-controlled, randomized, crossover study. Mediat. Inflamm. 2013. [CrossRef] [PubMed]

137. Wlosinska, M.; Nilsson, A.-C.; Hlebowicz, J.; Fakhro, M.; Malmsjö, M.; Lindstedt, S. Aged garlic extract reduces IL-6: A doubleblind placebo-controlled trial in females with a low risk of cardiovascular disease. Evidence-Based Complement. Altern. Med. 2021. [CrossRef] 
138. O'Rourke, M. Arterial stiffness, systolic blood pressure, and logical treatment of arterial hypertension. Hypertension 1990, 15, 339-347. [CrossRef] [PubMed]

139. Te Riet, L.; van Esch, J.H.M.; Roks, A.J.M.; van den Meiracker, A.H.; Danser, A.H.J. Hypertension: Renin-angiotensin-aldosterone system alterations. Circ. Res. 2015, 116, 960-975. [CrossRef] [PubMed]

140. Ried, K.; Travica, N.; Sali, A. The effect of aged garlic extract on blood pressure and other cardiovascular risk factors in uncontrolled hypertensives: The AGE at Heart trial. Integr. Blood Press. Control 2019, 9, 9. [CrossRef]

141. Ried, K.; Travica, N.; Sali, A. The effect of Kyolic aged garlic extract on gut microbiota, inflammation, and cardiovascular markers in hypertensives: The GarGIC Trial. Front. Nutr. 2018, 7, 122. [CrossRef]

142. Ried, K.; Frank, O.R.; Stocks, N.P. Aged garlic extract lowers blood pressure in patients with treated but uncontrolled hypertension: A randomised controlled trial. Maturitas 2010, 67, 144-150. [CrossRef]

143. Castro, C.; Lorenzo, A.G.; González, A.; Cruzado, M. Garlic components inhibit angiotensin II-induced cell-cycle progression and migration: Involvement of cell-cycle inhibitor p27Kip1 and mitogen-activated protein kinase. Mol. Nutr. Food Res. 2010, 54, 781-787. [CrossRef]

144. Yu, J.; Shan, Y.; Li, S.; Zhang, L. Potential contribution of Amadori compounds to antioxidant and angiotensin I converting enzyme inhibitory activities of raw and black garlic. LWT-Food Sci. Technol. 2020, 129, 109553. [CrossRef]

145. Jang, E.-K.; Seo, J.-H.; Lee, S.-P. Physiological activity and antioxidative effects of aged black garlic (Allium sativum L.) extract. Korean J. Food Sci. Technol. 2008, 40, 443-448.

146. Han, Y.; Fan, Z.D.; Yuan, N.; Xie, G.Q.; Gao, J.; De, W.; Gao, X.Y.; Zhu, G.Q. Superoxide anions in the paraventricular nucleus mediate the enhanced cardiac sympathetic afferent reflex and sympathetic activity in renovascular hypertensive rats. J. Appl. Physiol. 2011, 110, 646-652. [CrossRef] [PubMed]

147. Miao, Y.; Chen, J.; Zhou, G.; Xu, X.; Zhang, Q.; Wang, J. The antihypertensive effect of black garlic (Allium sativum) in spontaneously hypertensive rats via Scavenging of free radicals. Res. Health Nutr. 2014, 2, 5-12.

148. Peters, E.B.; Kibbe, M.R. Nanomaterials to Resolve Atherosclerosis. ACS Biomater. Sci. Eng. 2020, 6, 3693-3712. [CrossRef]

149. Morihara, N.; Hino, A.; Yamaguchi, T.; Suzuki, J. Aged Garlic Extract Suppresses the Development of Atherosclerosis in Apolipoprotein E-Knockout Mice. J. Nutr. 2016, 146, 460S-463S. [CrossRef] [PubMed]

150. Efendy, J.L.; Simmons, D.L.; Campbell, G.R.; Campbell, J.H. The effect of the aged garlic extract, Kyolic', on the development of experimental atherosclerosis. Atherosclerosis 1997, 132, 37-42. [CrossRef]

151. Wlosinska, M.; Nilsson, A.C.; Hlebowicz, J.; Hauggaard, A.; Kjellin, M.; Fakhro, M.; Lindstedt, S. The effect of aged garlic extract on the atherosclerotic process-A randomized double-blind placebo-controlled trial. BMC Complement. Med. Ther. 2020, 20, $1-10$.

152. Zeb, I.; Ahmadi, N.; Kadakia, J.; Larijani, V.N.; Flores, F.; Li, D.; Budoff, M.J.; Nasir, K. Aged garlic extract and coenzyme Q10 have favorable effect on inflammatory markers and coronary atherosclerosis progression: A randomized clinical trial. J. Cardiovasc. Dis. Res. 2012, 3, 185-190. [CrossRef]

153. Budoff, M.J.; Ahmadi, N.; Gul, K.M.; Liu, S.T.; Flores, F.R.; Tiano, J.; Takasu, J.; Miller, E.; Tsimikas, S. Aged garlic extract supplemented with B vitamins, folic acid and L-arginine retards the progression of subclinical atherosclerosis: A randomized clinical trial. Prev. Med. 2009, 49, 101-107. [CrossRef]

154. Zeb, I.; Ahmadi, N.; Flores, F.; Budoff, M.J. Randomized trial evaluating the effect of aged garlic extract with supplements versus placebo on adipose tissue surrogates for coronary atherosclerosis progression. Coron. Artery Dis. 2018, 29, 325-328. [CrossRef]

155. Ried, K.; Frank, O.R.; Stocks, N.P. Aged garlic extract reduces blood pressure in hypertensives: A dose-response trial. Eur. J. Clin. Nutr. 2013, 67, 64-70. [CrossRef]

156. Chauhan, N.B. Effect of aged garlic extract on APP processing and tau phosphorylation in Alzheimer's transgenic model Tg2576. J. Ethnopharmacol. 2006, 108, 385-394. [CrossRef] [PubMed]

157. Jeong, J.H.; Jeong, H.R.; Jo, Y.N.; Kim, H.J.; Shin, J.H.; Heo, H.J. Ameliorating effects of aged garlic extracts against A $\beta$-induced neurotoxicity and cognitive impairment. BMC Complement. Altern. Med. 2013, 13, 1-11.

158. Wichai, T.; Pannangrong, W.; Welbat, J.; Chaichun, A.; Sripanidkulchai, K.; Sripanidkulchai, B. Effects of aged garlic extract on spatial memory and oxidative damage in the brain of amyloid-ßinduced rats. Songklanakarin J. Sci. Technol. 2019, 41, 311-318.

159. Thorajak, P.; Pannangrong, W.; Welbat, J.U.; Chaijaroonkhanarak, W.; Sripanidkulchai, K.; Sripanidkulchai, B. Effects of aged garlic extract on cholinergic, glutamatergic and GABAergic systems with regard to cognitive impairment in A $\beta$-induced rats. Nutrients 2017, 9, 686. [CrossRef]

160. Ray, B.; Chauhan, N.B.; Lahiri, D.K. Oxidative insults to neurons and synapse are prevented by aged garlic extract and S-allyl-1cysteine treatment in the neuronal culture and APP-Tg mouse model. J. Neurochem. 2011, 117, 388-402. [CrossRef]

161. Zhou, H.; Qu, Z.; Mossine, V.V.; Nknolise, D.L.; Li, J.; Chen, Z.; Cheng, J.; Greenlief, C.M.; Mawhinney, T.P.; Brown, P.N.; et al. Proteomic analysis of the effects of aged garlic extract and its FruArg component on lipopolysaccharide-induced neuroinflammatory response in microglial cells. PLoS ONE 2014, 9, e113531. [CrossRef] [PubMed]

162. Rojas, P.; Serrano-Garcia, N.; Medina-Campos, O.N.; Pedraza-Chaverri, J.; Maldonado, P.D.; Ruiz-Sánchez, E. S-Allylcysteine, a garlic compound, protects against oxidative stress in 1-methyl-4-phenylpyridinium-induced parkinsonism in mice. J. Nutr. Biochem. 2011, 22, 937-944. [CrossRef] 
163. Ashafaq, M.; Khan, M.M.; Raza, S.; Ahmad, A.; Khuwaja, G.; Javed, H.; Khan, A.; Islam, F.; Siddiqui, M.S.; Safhi, M.M.; et al. S-allyl cysteine mitigates oxidative damage and improves neurologic deficit in a rat model of focal cerebral ischemia. Nutr. Res. 2010, 32, 133-143. [CrossRef]

164. Cervantes, M.I.; Balderas, P.M.D.O.; Gutiérrez-Baños, J.D.J.; Orozco-Ibarra, M.; Rojas, B.F.; Medina-Campos, O.N.; Espinoza-Rojo, M.; Ruiz-Tachiquín, M.; Ortiz-Plata, A.; Salazar, M.I.; et al. Comparison of antioxidant activity of hydroethanolic fresh and aged garlic extracts and their effects on cerebral ischemia. Food Chem. 2013, 140, 343-352. [CrossRef] [PubMed]

165. Atif, F.; Yousuf, S.; Agrawal, S.K. S-Allyl L-cysteine diminishes cerebral ischemia-induced mitochondrial dysfunctions in hippocampus. Brain Res. 2009, 1265, 128-137. [CrossRef]

166. Colin-González, A.L.; Ortiz-Plata, A.; Villeda-Hernández, J.; Barrera, D.; Molina-Jijón, E.; Pedraza-Chaverrí, J.; Maldonado, P.D. Aged garlic extract attenuates cerebral damage and cyclooxygenase-2 induction after ischemia and reperfusion in rats. Plant Foods Hum. Nutr. 2011, 66, 348-354. [CrossRef]

167. Gomez, C.D.; Aguilera, P.; Ortiz Plata, A.; Nares López, F.; Chanez Cardenas, M.E.; Flores Alfaro, E.; Ruiz-Tachiquín, M.E.; Espinoza-Rojo, M. Aged garlic extract and S-allylcysteine increase the GLUT3 and GCLC expression levels in cerebral ischemia. Adv. Clin. Med. Exp. 2019, 28, 1609-1614. [CrossRef] [PubMed]

168. Liu, Y.; Yan, J.; Han, X.; Hu, W. Garlic-derived compound S-allylmercaptocysteine (SAMC) is active against anaplastic thyroid cancer cell line 8305C (HPACC). Technol. Health Care 2015, 23, S89-S93. [CrossRef]

169. Yang, G.Q.; Wang, D.; Wang, Y.S.; Wang, Y.Y.; Yang, K. Radiosensitization effect of black garlic extract on lung cancer cell line Lewis cells. [Zhongguo Zhong xi yi jie he za zhi Zhongguo Zhongxiyi jiehe zazhi.] Chin. J. Integr. Tradit. West. Med. 2013, 33, $1093-1097$.

170. Jikihara, H.; Qi, G.; Nozoe, K.; Hirokawa, M.; Sato, H.; Sugihara, Y.; Shimamoto, F. Aged garlic extract inhibits 1, 2dimethylhydrazine-induced colon tumor development by suppressing cell proliferation. Oncol. Rep. 2015, 33, 1131-1140. [CrossRef]

171. Shin, D.Y.; Yoon, M.K.; Choi, Y.W.; Gweon, O.C.; Kim, J.I.; Choi, T.H.; Choi, Y.H. Effects of aged black garlic extracts on the tight junction permeability and cell invasion in human gastric cancer cells. J. Life Sci. 2010, 20, 528-534. [CrossRef]

172. Alkreathy, H.M.; AlShehri, N.F.; Kamel, F.O.; Alghamdi, A.K.; Esmat, A.; Karim, S. Aged garlic extract potentiates doxorubicin cytotoxicity in human breast cancer cells. Trop. J. Pharm. Res. 2020, 19, 1669-1676. [CrossRef]

173. Sigounas, G.; Hooker, J.; Anagnostou, A.; Steiner, M. S-allylmercaptocysteine inhibits cell proliferation and reduces the viability of erythroleukemia, breast, and prostate cancer cell lines. Nutr. Cancer 1997, 27, 186-191. [CrossRef] [PubMed]

174. Chu, Q.; Ling, M.T.; Feng, H.; Cheung, H.W.; Tsao, S.W.; Wang, X.; Wong, Y.C. A novel anticancer effect of garlic derivatives: Inhibition of cancer cell invasion through restoration of E-cadherin expression. Carcinogenesis 2006, 27, 2180-2189. [CrossRef]

175. Pinto, J.T.; Qiao, C.; Xing, J.; Rivlin, R.S.; Protomastro, M.L.; Weissler, M.L.; Tao, Y.; Thaler, H.; Heston, W.D. Effects of garlic thioallyl derivatives on growth, glutathione concentration, and polyamine formation of human prostate carcinoma cells in culture. Am. J. Clin. Nutr. 1997, 66, 398-405. [CrossRef]

176. Pinto, J.T.; Qiao, C.; Xing, J.; Suffoletto, B.P.; Schubert, K.B.; Rivlin, R.S.; Huryk, R.F.; Bacich, D.J.; Heston, W.D. Alterations of prostate biomarker expression and testosterone utilization in human LNCaP prostatic carcinoma cells by garlic-derived S-allylmercaptocysteine. Prostate 2020, 45, 304-314. [CrossRef]

177. Howard, E.W.; Ling, M.-T.; Chua, C.W.; Cheung, H.W.; Wang, X.; Wong, Y.C. Garlic-derived S-allylmercaptocysteine is a novel in vivo antimetastatic agent for androgen-independent prostate cancer. Clin. Cancer Res. 2007, 13, 1847-1856. [CrossRef] [PubMed]

178. Howard, E.W.; Lee, D.T.; Chiu, Y.T.; Chua, C.W.; Wang, X.; Wong, Y.C. Evidence of a novel docetaxel sensitizer, garlic-derived S-allylmercaptocysteine, as a treatment option for hormone refractory prostate cancer. Int. J. Cancer. 2008, 122, 1941-1948. [CrossRef] [PubMed]

179. Tong, D.; Qu, H.; Meng, X.; Jiang, Y.; Liu, D.; Ye, S.; Chen, H.; Jin, Y.; Fu, S.; Geng, J. S-allylmercaptocysteine promotes MAPK inhibitor-induced apoptosis by activating the TGF- $\beta$ signaling pathway in cancer cells. Oncol. Rep. 2014, 32, 1124-1132. [CrossRef]

180. Xu, K.X.; Hu, H.; Zhang, X.P.; Wang, Y.L.; Chua, C.W.; Luk, S.U.; Wong, Y.C.; Ling, M.T.; Wang, X.F. Identification of a novel function of Id-1 in mediating the anticancer responses of SAMC, a water-soluble garlic derivative, in human bladder cancer cells. Mol. Med. Rep. 2011, 4, 9-16. [CrossRef] [PubMed]

181. Wu, J.; Zhao, S.; Zhang, J.; Qu, X.; Jiang, S.; Zhong, Z.; Zhang, F.; Wong, Y.; Chen, H. Over-expression of survivin is a factor responsible for differential responses of ovarian cancer cells to S-allylmercaptocysteine (SAMC). Exp. Mol. Pathol. 2016, 100, 294-302. [CrossRef] 